\title{
Convection-type PEM fuel cell control system performance testing and modeling
}

Jeannette M. Hoy

West Virginia University

Follow this and additional works at: https://researchrepository.wvu.edu/etd

\section{Recommended Citation}

Hoy, Jeannette M., "Convection-type PEM fuel cell control system performance testing and modeling" (2008). Graduate Theses, Dissertations, and Problem Reports. 1907.

https://researchrepository.wvu.edu/etd/1907

This Thesis is protected by copyright and/or related rights. It has been brought to you by the The Research Repository @ WVU with permission from the rights-holder(s). You are free to use this Thesis in any way that is permitted by the copyright and related rights legislation that applies to your use. For other uses you must obtain permission from the rights-holder(s) directly, unless additional rights are indicated by a Creative Commons license in the record and/ or on the work itself. This Thesis has been accepted for inclusion in WVU Graduate Theses, Dissertations, and Problem Reports collection by an authorized administrator of The Research Repository @ WVU. For more information, please contact researchrepository@mail.wvu.edu. 


\title{
Convection-Type PEM Fuel Cell Control System Performance Testing and Modeling
}

\author{
Jeannette M. Hoy \\ Thesis submitted to the \\ College of Engineering and Mineral Resources \\ at West Virginia University \\ in partial fulfillment for the requirements \\ for the degree of \\ Master of Science \\ in \\ Electrical Engineering \\ Committee Members: \\ Powsiri Klinkhachorn, Ph.D., Chair \\ Roy S. Nutter, Ph.D. \\ Mohammad A. Choudhry, Ph.D. \\ Lane Department of Computer Science and Electrical Engineering \\ Morgantown, WV \\ 2008
}

Keywords: PEM Fuel Cell, Modeling, Dead-ended Hydrogen Purging

Copyright 2008. Jeannette M. Hoy 


\section{Abstract \\ Convection-Type PEM Fuel Cell Control System Performance Testing and Modeling by Jeannette M. Hoy}

The PEM (Polymer Electrolyte Membrane) fuel cell is a promising technology for mobile applications because of its compactness, low operating temperature, and quick startup time. The following study evaluates the efficiency of convection type PEM fuel cells by conducting a series of tests on two commercially available fuel cells, and examines each fuel cell's control methods to identify the key factors for the each cell's fuel and air management. The control system affects the stack by purging a dead-ended stack, which stabilizes the performance of the fuel cell by periodically purging the system of contaminants or water building up in the system and maintains the input hydrogen pressure; and the fan speed, which controls the temperature and helps pull air into the stack. The purging system was determined to have a large part in maintaining the performance of the fuel cell over time, with the fuel cell's output consistently deteriorating over time if kept dead-ended. Purging too often also had the effects of wasting hydrogen and unbalancing the internal pressures of the fuel cell. It was determined that the period between purges was most effective when dependent on the power drawn from the fuel cell and the rate of the fuel cell's voltage drop.

By observing the performance of two similar PEM fuel cells, the Jadoo and Horizon $100 \mathrm{~W}$ fuel cells, the efficiency of their control systems could be compared and evaluated. The Jadoo purging system worked most efficiently at loads between 40-70W, which appeared to be the time when the fan was used to introduce the most sufficient amount of air into the stack and the purging period was 20 minutes. The average practical efficiency of the $100 \mathrm{~W}$-rated fuel cell was $42 \%$, while the peak practical efficiency $48 \%$ at $62 \mathrm{~W}$. When run at higher power outputs that required more frequent purging, there was a small decline in the efficiency; and the fuel cell's lowest efficiency occurred when run at the low power outputs of $20 \mathrm{~W}$ or less when most of the power from the fuel cell was diverted to the control unit. The Horizon fuel cell was purged whenever the voltage had dropped below a certain threshold, and had an overall average efficiency of $34 \%$ reaching higher efficiencies when run at lower power outputs. Its highest measured efficiency peaked at $48 \%$ at $11 \mathrm{~W}$, which was when the fuel cell required the lowest purging frequency. Models of the Jadoo PEM fuel cell were developed in the MATLAB/SIMULINK environment using the experimental data that incorporated the effects of keeping stack dead-ended. 


\section{Acknowledgments}

As a graduate student, I have had the great privilege to have studied and worked with many kind and intelligent people without whom this work would not have been possible. Foremost of these, I would like to thank my supervisor Dr. Powsiri Klinkhachorn for his guidance and encouragement these past few years. He helped me choose and develop this topic, and always has high expectations that have helped push me to work at a higher level. I would also like to express my gratitude to Koorsosh Mirfakhraie of Augusta Systems, Inc. for taking a great interest in the project and for all of his help with the testing and acquiring of equipment, and to Dr. John Zondlo and Dr. Chunchuan Xu of the WVU Chemical Engineering Department for their advice and for letting us borrow their hydrogen and fume hood.

I am also very grateful for my teachers and fellow students here at WVU, all of whom have made my experience here a very wonderful and enriching one.

Going outside of the engineering department, I would like to thank Jillian Shumaker, who has been my best friend and occasional editor since junior high, and my cousin Shelley Layman, who is always there to encourage me.

Finally, I cannot express enough love and appreciation for my parents, who have stood by me as mentors, as friends, and as pillars of support. Everything I have achieved is because of them. 


\section{Table of Contents}

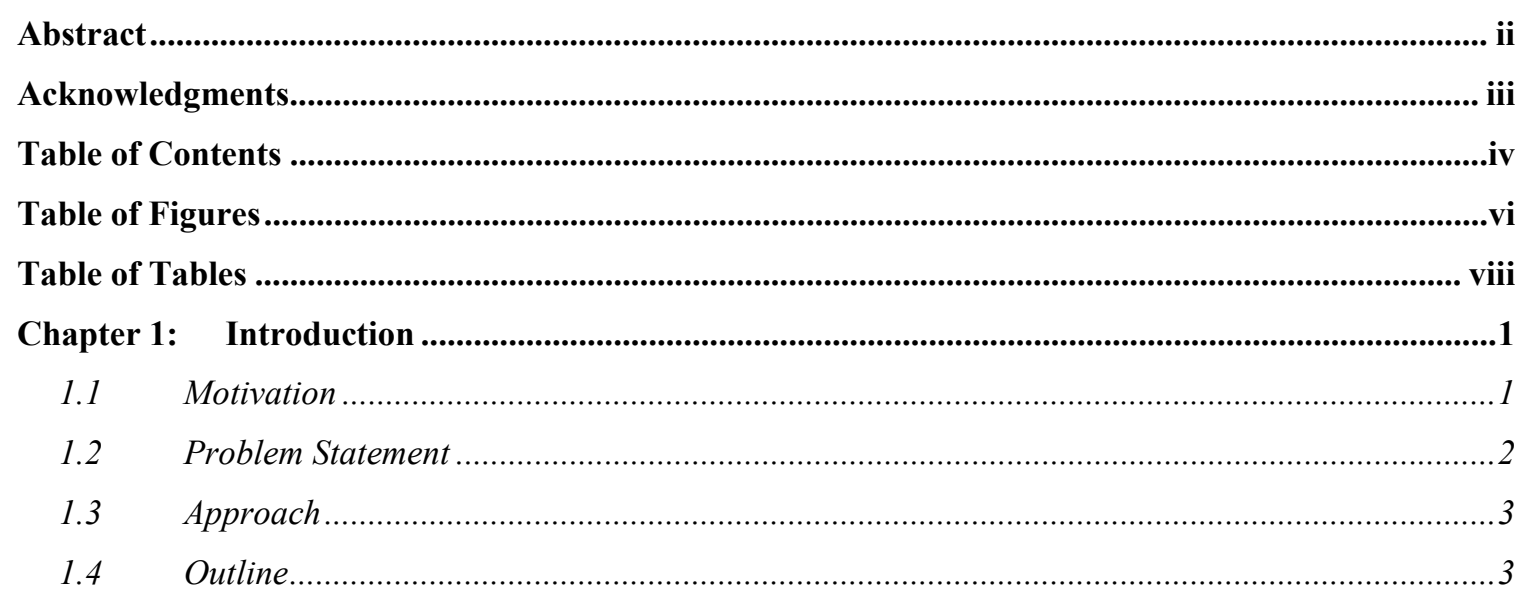

Chapter 2: Literature Review.......................................................................................................................5

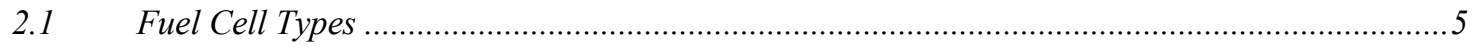

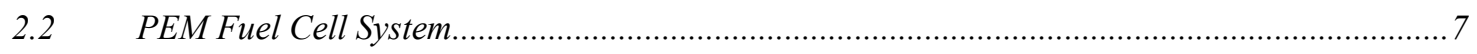

2.2.1 PEM Fuel Cell Chemical Reactions ..................................................................................

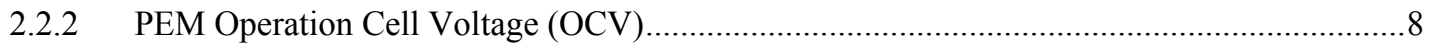

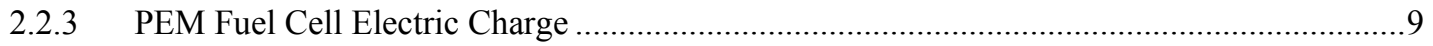

2.2.4 PEM Fuel Cell Hydrogen Consumption..........................................................................

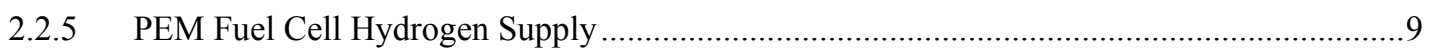

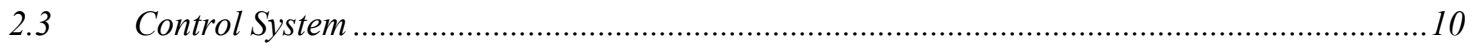

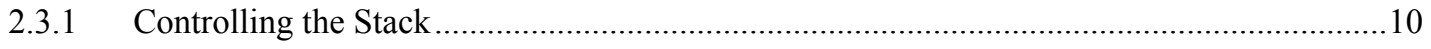

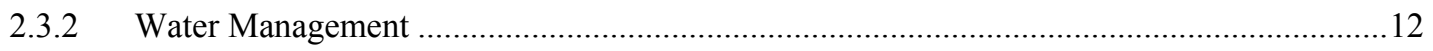

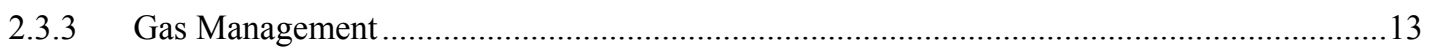

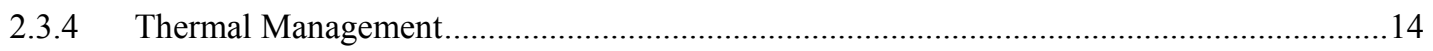

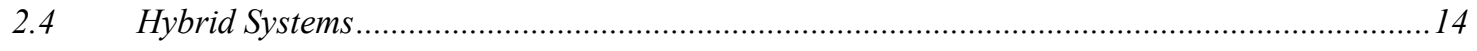

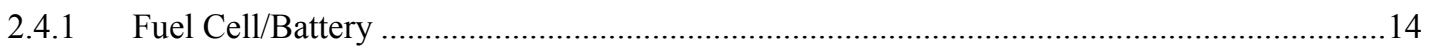

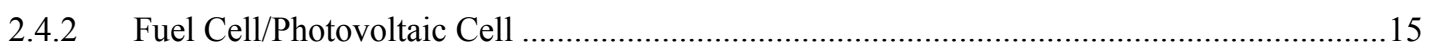

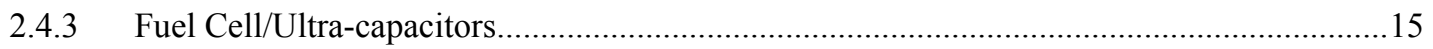

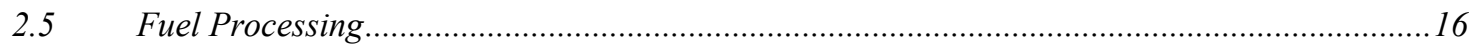

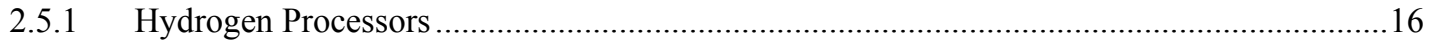

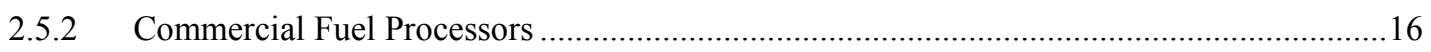

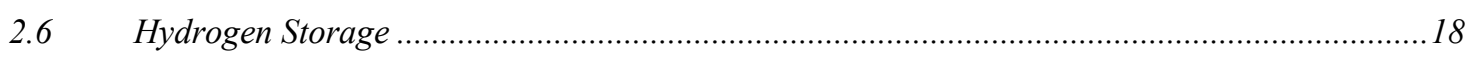

Chapter 3: Fuel Cell Control System .......................................................................................................19

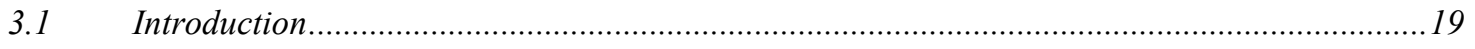

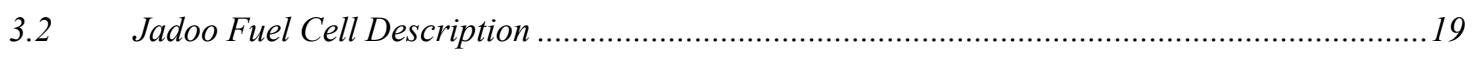

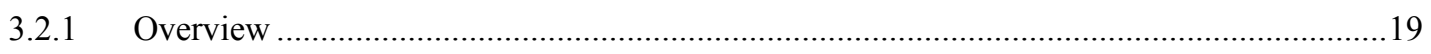




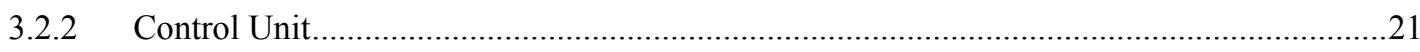

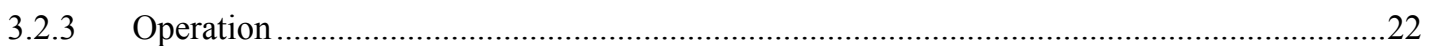

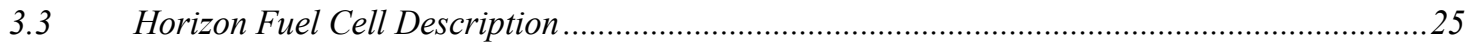

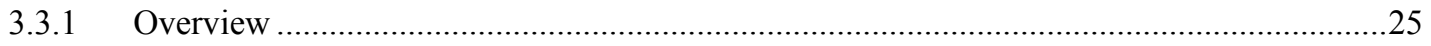

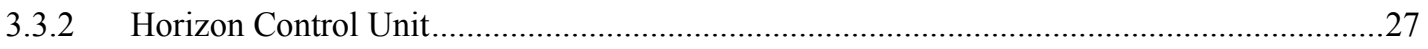

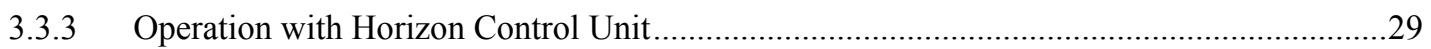

3.3.4 User-Created Control Unit.........................................................................................

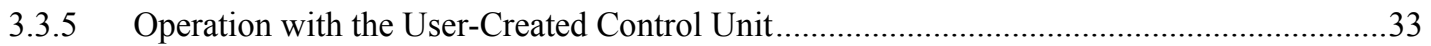

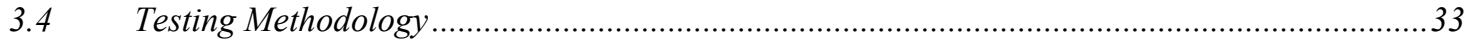

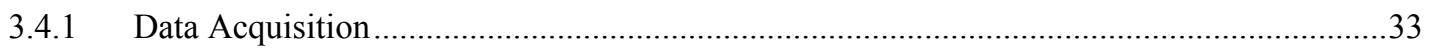

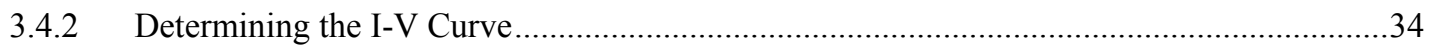

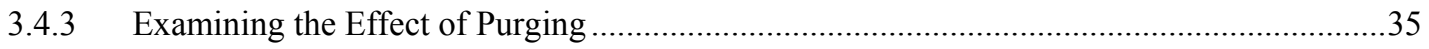

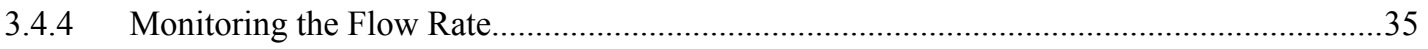

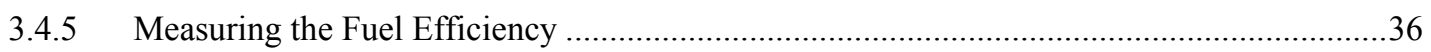

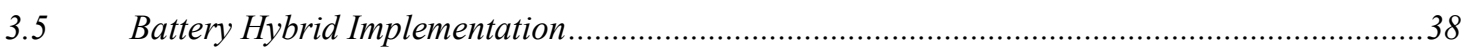

Chapter 4: Test Results .......................................................................................................................................40

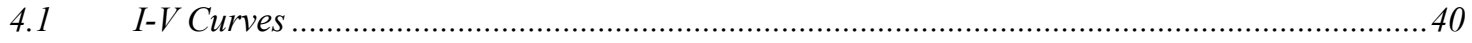

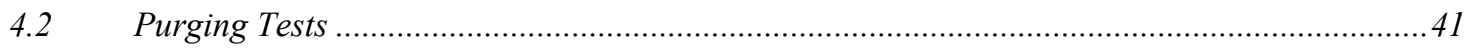

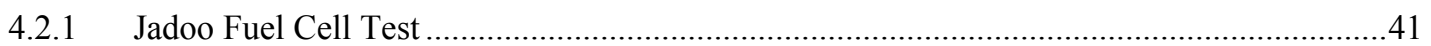

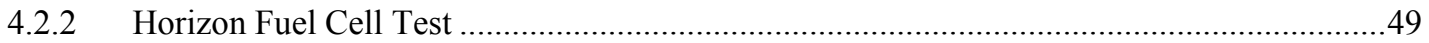

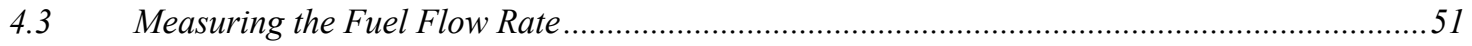

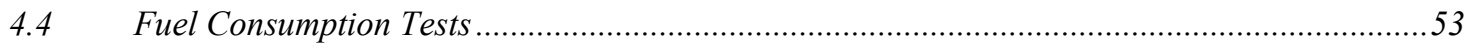

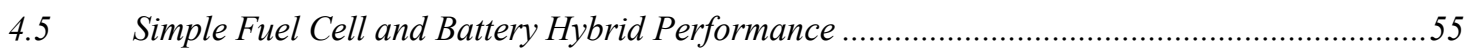

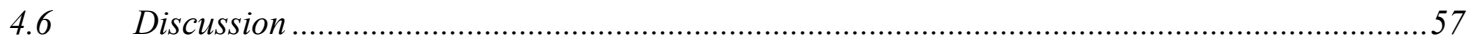

Chapter 5: $\quad$ Dead-Ended Anode PEM Model ................................................................................................59

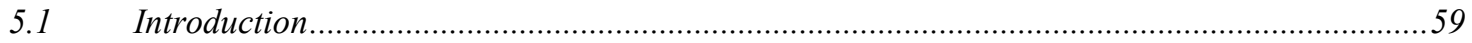

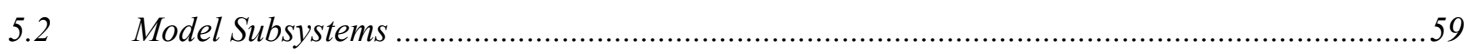

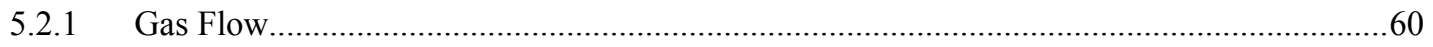

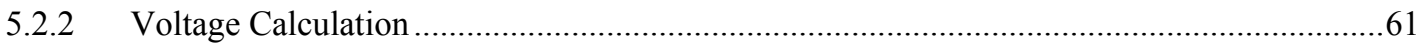

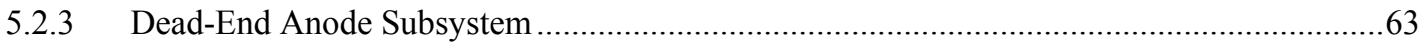

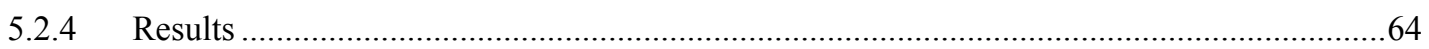

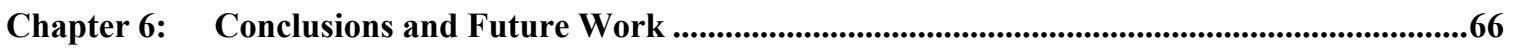

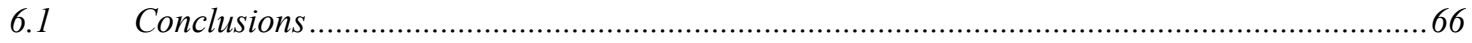

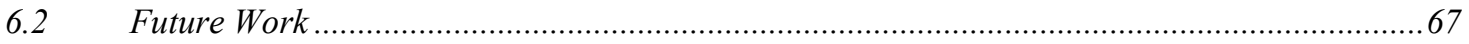

Bibliography .................................................................................................................................................68

Appendices ..........................................................................................................................................................72 


\section{Table of Figures}

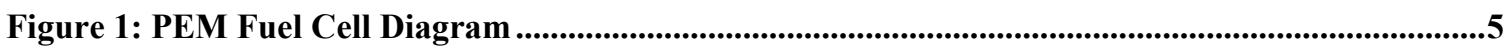

Figure 2: Dead-ended with purging hydrogen supply method...................................................................8

Figure 3: Power Management System accounting for load fluctuations [8] .............................................12

Figure 4: Fuel Cell Hybrid Vehicle System Diagram [14] .......................................................................14

Figure 5: PEM Fuel Cell with Ultracapacitors [16] ..............................................................................15

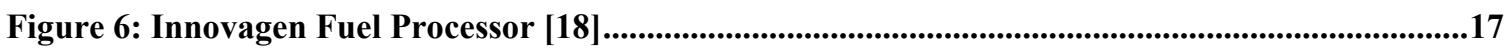

Figure 7: Compact Logistics Fuel Processor [19] ....................................................................................17

Figure 8: Original Image of Jadoo N-Gen connected to a variable light bulb bank ..............................19

Figure 9: Jadoo System Setup ........................................................................................................................21

Figure 10: Jadoo Hydrogen regulator and solenoid ...........................................................................22

Figure 11: Jadoo Purging Solenoid.................................................................................................................22

Figure 12: Flowchart of Events During Jadoo System Start-u p ...............................................................23

Figure 13: Flowchart of Events during Jadoo Operation ...............................................................................24

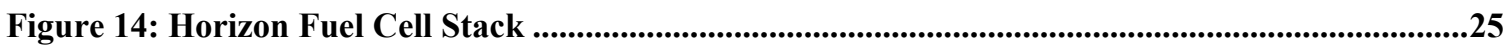

Figure 15: Metal Hydride Hydrogen Tank ..........................................................................................................26

Figure 16: Low Pressure Gauge, Regulator, and High Pressure Gauge ...................................................26

Figure 17: Original Horizon Fuel Cell Controller..................................................................................28

Figure 18: Horizon System Setup ..................................................................................................28

Figure 19: Hydrogen sensor and purging valve..........................................................................................29

Figure 20: Voltage and solenoid signals of Horizon Fuel Cell.....................................................................30

Figure 21: Control interface for the Horizon fuel cell stack............................................................................31

Figure 22: User-created controller Labview block diagram .........................................................................31

Figure 23: User-created controller functionality diagram................................................................................32

Figure 24: Fuel Cell/Battery Setup with Battery Charger................................................................................38

Figure 25: Horizon I-V Curves .....................................................................................................................40

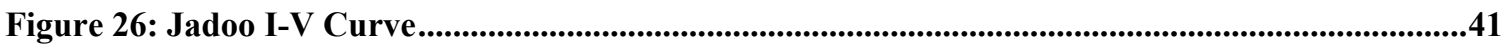

Figure 27: Jadoo Low Power Performance........................................................................................42

Figure 28: Jadoo High Power Performance..................................................................................................42

Figure 29: Overview of Stack and Solenoid Voltages with Stack Current...............................................43

Figure 30: Individual Stack Levels with Stack Current and Solenoid Signals ..........................................44

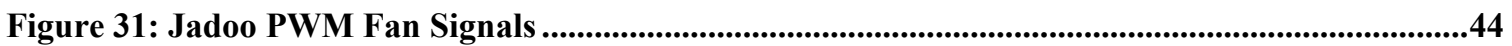

Figure 32: Overview of all Jadoo signals, stack voltages, and current with and without purging........45

Figure 33: Overview of all Jadoo Signals after a Sudden Heavy Load Without Purging.....................46

Figure 34: Individual Jadoo Stack Voltage after a Sudden Heavy Load was Introduced ......................46

Figure 35: Jadoo fan behavior after heavy load addition .............................................................................47 
Figure 36: Jadoo signals during slow increase of the load without purging ............................................47

Figure 37: Fan readings during slow load increase ......................................................................48

Figure 38: Overview of all signal behavior with and without purging system............................................48

Figure 39: Fan behavior with and without purging .....................................................................................49

Figure 40: Voltage Behavior Graph of the Horizon Low Power Test ......................................................49

Figure 41: Voltage Behavior Graph of the Horizon High Power Test........................................................50

Figure 42: Power versus Flow Rate ..........................................................................................................51

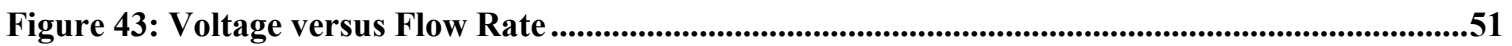

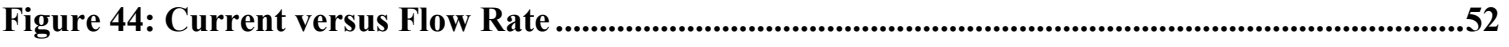

Figure 45: Comparing the Jadoo Actual Flow and Consumption Rates..............................................52

Figure 46: Comparing the Horizon Actual Flow and Consumption Rates ...............................................53

Figure 47: Comparing the Horizon and Jadoo Energy Densities...................................................................54

Figure 48: Jadoo Fuel Efficiency and Energy Density ....................................................................................54

Figure 49: Horizon Fuel Efficiency and Energy Density ........................................................................55

Figure 50: Battery only performance ..............................................................................................................56

Figure 51: Fuel Cell/Battery current behavior with charger ..........................................................................56

Figure 52: Fuel Cell/Battery/Load current behavior with charger...............................................................57

Figure 53: Subsystem Model Block Diagram......................................................................................................59

Figure 54: Anode Hydrogen Flow...............................................................................................................61

Figure 55: Voltage Calculation..................................................................................................................62

Figure 56: Activation Voltage Loss Model ...................................................................................................63

Figure 57: Concentration Voltage Loss Model ......................................................................................63

Figure 58: Voltage Drop over Time per Ampere.................................................................................64

Figure 59: Dead-End Anode Simulation .......................................................................................................64

Figure 60: Model and Jadoo IV Curves .........................................................................................................64

Figure 61: Model Performance Over Time With Increasing Current......................................................65

Figure 62: Model Output With and Without the Dead-Ended Anode Voltage Drop..............................65 


\section{Table of Tables}

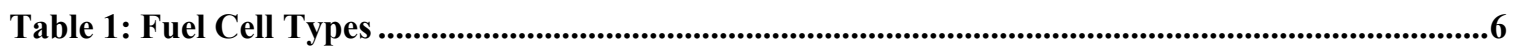

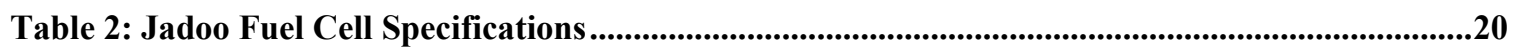

Table 3: Jadoo Fuel Canister Specifications ...................................................................................21

Table 4: Horizon Specifications ...................................................................................................27

Table 5: Ovonics Hydrogen Canister Specifications ...........................................................................................27

Table 6: Battery Specifications......................................................................................................................38

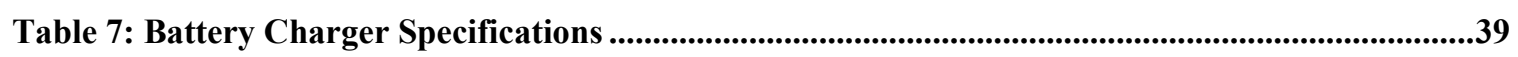




\section{Chapter 1: Introduction}

\subsection{Motivation}

In these days of constant technological advance, the need for more energy keeps growing, and the current most popular energy sources, especially for mobile applications, rely on non-renewable fossil fuels. Unfortunately, a number of problems have developed because of this over-dependence of fossil fuels. There is the negative impact the pollution released when using such fuels that affect environment causing global warming, acid rain, and pollution. Another is the simple fact that these fuels are eventually going to deplete completely, and even now are becoming more costly to obtain. With the increasing awareness of how greenhouse gases are having such a detrimental effect on global warming in the environment, and with the current, more popular, non-reusable fuels growing more expensive; it is becoming more and more important to determine alternate forms of power production. One such method that is becoming more viable is the use of fuel cells.

Although the technology of fuel cells has existed for over a century, past developers had consistently overlooked the potential of the technology in favor of the combustion methods, which, while having less overall efficiency, had been less costly to develop. Fuel cells produce power solely from the electrochemical reactions of its fuel and oxidant, and as such, they can reach much higher efficiencies than internal combustion engines, which are subject to the limitations of the Carnot Cycle. Additionally, the fuel cells themselves, if fueled with hydrogen, have only water and heat as byproducts. Other fuels, such as hydrocarbons or liquid hydrocarbons, can be used with processing units, but there will be additional wastes. Unfortunately, even with these benefits, although research with new materials and methods has lowered the price, fuel cells are still expensive to produce and hydrogen is difficult and costly to produce and store.

Generally, cost has limited the use of fuel cells to military and luxury applications; however, focus on fuel cell technology has significantly increased in the last 40 years, beginning with NASA's use of the Alkaline Fuel Cell (AFC) in its shuttles 
during the 1960s [1], and researchers have developed several methods to improve upon their performance and cost. With improved methods of hydrogen production, reforming, and storage, and exploration into other potential fuels such as ethanol or methanol, fuel cells have proven to be a viable, though still moderately expensive, option.

Researchers have developed a number of different types of fuel cells, and each has its advantages and disadvantages that make them better suited to specific applications. On one end, there is the high-powered Solid Oxide Fuel Cell (SOFC) that operates at very high temperatures, and on the other, there is the lower-powered Polymer Electrolyte Membrane (PEM) fuel cell that operates on very low temperatures. The PEM fuel cell requires components that are more expensive and fuels with a higher purity; but they are also small, lightweight, quick-to-start, and with relatively low-temperature operation. All of which make it the most popular choice for mobile applications.

There are still a number of challenges to meet in order to make fuel cells become a more affordable solution. This study is intended to determine optimal methods of controlling a PEM fuel cell's output, determining the best possible range of operation to minimize the hydrogen consumption, and integrating it into a fuel cell/battery hybrid system capable of power outputs much higher than a fuel cell's range. Additionally, access to commercial fuel cells allows for development of a model based on not only theoretical equations but also experimental data.

\subsection{Problem Statement}

The first main objective of this thesis is to determine the optimal methods of controlling a convection type PEM fuel cell by means of the following:

- Developing a literature survey of existing technologies involved in using the fuel cell,

- Testing the efficiency of two commercially available fuel cells of that type and comparing the results with theoretical performance of a PEM fuel cell,

- Studying the effects on the main system controls consisting of:

- Purging the dead-ended stack,

- Altering the fan speed blowing into the stack, and

- Raising or lowering the input pressure. 
The second main objective is to use the experimental data, obtained by testing each system control, into a MATLAB model that can simulate the performance of the convection type PEM fuel cells and incorporate controls mentioned above.

\subsection{Approach}

To accomplish this objective, two commercially available fuel cells and their control units were subjected to a number of tests to determine their efficiency and performance. The provided control units of both fuel cells were rigorously examined and compared, and a new control unit was developed for one of the fuel cells allowing additional variables, such as the cell stack's purging and fan speed, to be manipulated and their effects studied. With this, a model incorporating these variables within the theoretical equations could be developed based upon this experimental data.

To integrate the fuel cell into a hybrid system with a battery, first tests were done to evaluate the performance of the system if the fuel cell and battery were directly connected together with a load in order to examine how the fuel cell's control system would react in such a scenario. The next test was on the most basic method that incorporated a simple, inexpensive battery charger to control the output of the fuel cell into providing power to running the load and recharging the battery.

\subsection{Outline}

The second chapter of this thesis gives an overview of the fuel cell technology and the reasons the PEM fuel cell was selected for this project. It also details the methods developed for controlling the different aspects of the PEM fuel cell system. This includes the following areas: controlling the fuel cell stack; detailed techniques on managing the gas flows, water flows, and stack temperature; and possible methods to fuel

the stack. It also includes hybridization options and methods to store or process the hydrogen needed to fuel the cell.

The third chapter describes the methods the two commercially available fuel cells were tested to examine their control units and evaluate their efficiency and performance. Both fuel cells are convection-type PEM fuel cells with dead-ended hydrogen purging and rated for nominal power at $100 \mathrm{~W}$. The efficiency of each fuel cell was tested by 
determining the I-V curves, the fuel economy at different loads, the flow rates, and the hydrogen detected outside of the fuel cell. The controller of each fuel cell was studied, and each control method was tested to determine their effect on the system. To observe how the fuel cell would work in a simple hybridization system, a DC-DC converter was used with the fuel cell to charge a battery powering the load.

The fourth chapter examines and describes the results of the tests described in the third chapter and compares them to the theoretical equations of the PEM fuel cell.

The fifth chapter describes the model developed in the MATLAB/SIMULINK environment that was based upon the experimental data incorporating the effects of purging the dead-ended stack and comparing it with the actual performance of the fuel cell.

The sixth chapter lays out the conclusions of the thesis and postulates future directions the work can be directed. 


\section{Chapter 2: $\quad$ Literature Review}

\subsection{Fuel Cell Types}

Fuel cells use the electrochemical reactions of injected fuel and oxidant to produce electrical power with high efficiency and few byproducts. Figure 1 shows the basic diagram of a typical PEM fuel cell. The basic fuel cell consists of an anode and a cathode separated by an electrolyte. For the PEM fuel cell, the fuel (hydrogen) enters into the anode side and the oxidant (oxygen containing air) into the cathode. Inside the anode and cathode sections of the fuel cell, the fuel and oxidant gases are separated into ions and electrons. The electrolyte membrane allows the passage of hydrogen ions into the cathode where they rejoin with the oxygen ions to create water vapor, and it blocks the electrons from passing through, which forces them to travel through the external circuit attached into the fuel cell. Different types of fuel cells have different electrolytes that specify whether it is the fuel or oxidant ions that pass through; therefore in other fuel cells such as the SOFC, the water is produced on the anode side.

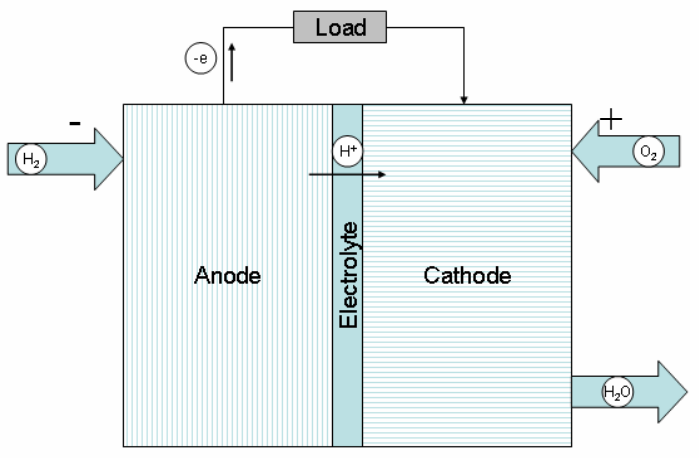

Figure 1: PEM Fuel Cell Diagram

There are numerous different types of fuel cells, and they are typically named after the materials used in their electrolytes. The two most commonly researched are the PEM and the SOFC, which represent the wide range available among fuel cells, and are among the most researched and commercialized [2]. The high-powered SOFC uses relatively inexpensive materials and is highly resistant to carbon monoxide, which in the PEM, can poison the oxidation reaction at the anode thus lowering the fuel cell's performance. The PEM's electrolyte is a polymer membrane that needs to be hydrated in 
order to operate, and the SOFC's electrolyte is a solid, non-porous metal oxide. The SOFC fuel cells have some of the highest power outputs, they are bulky, slow-to-start, and operate at very high temperatures from 800 to $1000^{\circ} \mathrm{C}$; making it more suited for stationary applications than the small, low-temperature PEM fuel cell.

Each fuel cell type has its characteristics that give them different advantages and disadvantages toward specific types of applications. The different types of fuel cells are summarized in Table 1 and described further below.

Table 1: Fuel Cell Types

\begin{tabular}{|l|l|l|l|l|l|l|}
\hline Type & $\begin{array}{l}\text { Operating } \\
\text { Temp }\end{array}$ & $\begin{array}{l}\text { Power } \\
\text { Density }\end{array}$ & $\begin{array}{l}\text { Typical } \\
\text { Catalysts }\end{array}$ & Electrolyte & Pros & Cons \\
\hline SOFC & $800-1000^{\circ} \mathrm{C}$ & $\begin{array}{l}250-350 \\
\mathrm{~mW} / \mathrm{cm}^{2}\end{array}$ & $\begin{array}{l}\text { Perovskite } \\
\text { (ceramic) }\end{array}$ & $\begin{array}{l}\text { Solid, non- } \\
\text { porous metal } \\
\text { oxide }\end{array}$ & $\begin{array}{l}\text { Highly } \\
\text { tolerant, } \\
\text { internal } \\
\text { reforming, } \\
\text { low cost }\end{array}$ & $\begin{array}{l}\text { Slow start, } \\
\text { High-temp }\end{array}$ \\
\hline $\mathrm{MCFC}$ & $600-700^{\circ} \mathrm{C}$ & $\begin{array}{l}100-300 \\
\mathrm{~mW} / \mathrm{cm}^{2}\end{array}$ & Nickel & $\begin{array}{l}\text { Alkali } \\
\text { carbonates in a } \\
\text { ceramic matrix }\end{array}$ & $\begin{array}{l}\text { High } \\
\text { efficiencies, } \\
\text { internal } \\
\text { reforming, } \\
\text { low cost }\end{array}$ & $\begin{array}{l}\text { Low } \\
\text { durability }\end{array}$ \\
\hline $\mathrm{AFC}$ & $80-250^{\circ} \mathrm{C}$ & $\begin{array}{l}150-400 \\
\mathrm{~mW} / \mathrm{cm}^{2}\end{array}$ & Platinum & KOH & $\begin{array}{l}\text { High } \\
\text { efficiencies }\end{array}$ & $\begin{array}{l}\text { Expensive, } \\
\text { Vulnerable } \\
\text { to CO }\end{array}$ \\
\hline $\mathrm{PAFC}$ & $150-220^{\circ} \mathrm{C}$ & $\begin{array}{l}150-300 \\
\mathrm{~mW} / \mathrm{cm}^{2}\end{array}$ & Platinum & $\begin{array}{l}\text { Phosphoric } \\
\text { Acid }\end{array}$ & $\begin{array}{l}\text { Low-temp, } \\
\text { quick start, } \\
\text { more } \\
\text { tolerant than } \\
\text { PEM }\end{array}$ & $\begin{array}{l}\text { Expensive } \\
\text { electrolytes, } \\
\text { large, low } \\
\text { power }\end{array}$ \\
\hline PEM & $60-80^{\circ} \mathrm{C}$ & $\begin{array}{l}300-1000 \\
\mathrm{~mW} / \mathrm{cm}^{2}\end{array}$ & Platinum & $\begin{array}{l}\text { Polymer } \\
\text { Membrane }\end{array}$ & $\begin{array}{l}\text { Low-temp, } \\
\text { quick start, } \\
\text { small }\end{array}$ & $\begin{array}{l}\text { Expensive } \\
\text { electrolytes, } \\
\text { CO } \\
\text { intolerance }\end{array}$ \\
\hline
\end{tabular}

Molten Carbonate Fuel Cells (MCFC), like the SOFC, are also more likely to be used for stationary applications and have an electrolyte composed of alkali carbonates retained in a ceramic matrix of $\mathrm{LiAlO}_{2}$. This fuel cell generally operates at temperatures from 600 to $700^{\circ} \mathrm{C}$, which is when the carbonates form highly conductive molten salts [1]. These fuel cells operate at such high temperatures that they do not need to use the typically expensive noble metal catalysts, and because the MCFC and the SOFC operate at such high temperatures, both are capable of internal reforming of hydrogen.

Alkaline Fuel Cells (AFC) were some of the earliest developed and used fuel cells in the NASA space program, and they typically use different concentrations of $\mathrm{KOH}$ as 
its electrolyte depending on the desired temperature operation. They can run at temperature below 120 and up to $250^{\circ} \mathrm{C}$ and can use a wide range of catalysts, but are very intolerant to carbon dioxide, which can poison the $\mathrm{KOH}$ electrolyte [2].

Phosphoric acid fuel cells (PAFC) are reliable with good long-term performance, have an electrolyte consisting of concentrated phosphoric acid contained in a $\mathrm{SiC}$ matrix, and typically run at temperatures from 150 to $220^{\circ} \mathrm{C}$. They are quite similar to the PEM fuel cells detailed below and often use platinum as their catalyst, but because of its higher operating temperature is somewhat more tolerant to $\mathrm{CO}$ poisoning. Its electrolyte is much less expensive than the PEM fuel cell's, but it is also corrosive and depletes while it is running [2].

The PEM fuel cell, which is concentrated on in this study, utilizes a thin proton conductive polymer membrane as its electrolyte and typically uses platinum as its catalyst. Thus, the relatively low-powered fuel cell requires expensive materials and higher purity fuel; but is small, lightweight, quick-to-start, and operates at very low temperatures of 60 to $80^{\circ} \mathrm{C}$, making it well suited to portable and automotive applications [1]. Because we are working with a mobile and relatively low power system, the fuel cell type determined most appropriate is the PEM fuel cell.

\subsection{PEM Fuel Cell System}

PEM fuel cells use a polymer membrane to generate electrochemical energy with hydrogen and air. The byproducts are heat and water, much of which is required in the membrane with any excess expelled from the cell. As shown in Figure 1, the PEM fuel cell's electrolyte allows the hydrogen ions $\left(\mathrm{H}^{+}\right)$through which combine with the oxygen ions $\left(\mathrm{O}^{-}\right)$on the cathode side forming water $\left(\mathrm{H}_{2} \mathrm{O}\right)$ molecules. The fuel cell will continue to provide power for as long as the fuel and oxidant are provided.

The optimal temperature range of the fuel cell is between $60^{\circ} \mathrm{C}$ and $80^{\circ} \mathrm{C}[1]$. The two main types of PEM fuel cell use different methods to input the reactants into the stack. The forced-flow type has both the hydrogen and oxygen inputs forced into the stack, while the convection-type only needs to force the hydrogen while letting air enter the stack through either natural or forced convection [3]. The commercial fuel cells in this study are both convection type with the free-flow of air and self-humidified, which 
indicates the fuel cells maintain the necessary water balance in the membrane using the water output of the stack. They also use a hydrogen purging system that periodically opens the dead-ended anode (as pictured in Figure 2) for short periods to purge contaminants and water which can cause obstructions of the gas flow [4].

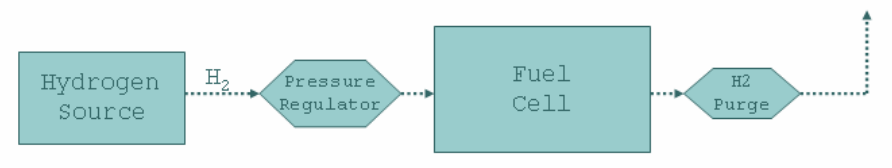

Figure 2: Dead-ended with purging hydrogen supply method

\subsubsection{PEM Fuel Cell Chemical Reactions}

The chemical reactions occurring within the fuel cell are as follows:

- Anode: $\mathrm{H}_{2}(\mathrm{~g}) \rightarrow 2 \mathrm{H}^{+}+2 \mathrm{e}^{-}$,

- Cathode: $1 / 2 \mathrm{O}_{2}(\mathrm{~g})+2 \mathrm{e}^{-}+2 \mathrm{H}^{+} \rightarrow \mathrm{H}_{2} \mathrm{O}(\mathrm{g})$,

- Overall: $\mathrm{H}_{2}(\mathrm{~g})+1 / 2 \mathrm{O}_{2}(\mathrm{~g}) \rightarrow \mathrm{H}_{2} \mathrm{O}(\mathrm{g})$.

From the above overall reaction equation, it can be seen that when a single mole of oxygen reacts, four electrons are released, and when a single mole of hydrogen reacts, two electrons are increased. The number of electrons produced in the reactions need to be known in order to determine the fuel (hydrogen) utilization and required airflows [1].

\subsubsection{PEM Operation Cell Voltage (OCV)}

The Operation Cell Voltage (OCV) must take into account the activations, ohmic, and concentration losses and is given by:

$O C V: \mathrm{V}=\mathrm{E}_{\mathrm{n}}-\Delta \mathrm{V}_{\text {act }}-\Delta \mathrm{V}_{\text {ohm }}-\Delta \mathrm{V}_{\text {conc, }}$ where:

Nernst Voltage: $E_{N}=E_{0}-\frac{R T}{n F} \ln \frac{C_{\text {red }}}{C_{o x}}$, and

$\mathrm{R}$ is the universal gas contant, $\mathrm{T}$ is the temperature, and $\mathrm{C}$ is the concentration of the reduction or oxidation agents. The losses are calculated by the following equations:

Activation Losses: $\Delta V_{\text {act }}=B \ln (i)-A$,

where $B=\frac{R T}{n \alpha F}, A=\frac{R T}{n \alpha F} \ln \left(i_{o}\right), \alpha$ is the transfer coefficient (typically 0.5 ), $\mathrm{i}$ is the current density, and $\mathrm{i}_{\mathrm{o}}$ is the exchange current density.

Ohmic Losses: $\quad \Delta V_{\text {ohm }}=i r$, 
where $\mathrm{i}$ is the current density and $\mathrm{r}$ is the area specific resistance of the fuel cell.

Concentration Losses: $\Delta V_{\text {conc }}=m \cdot \exp (\eta i)$,

where $\mathrm{i}$ is the current density, and $\mathrm{m}$ and $\mathrm{n}$ are empirical values [1].

\subsubsection{PEM Fuel Cell Electric Charge}

Looking at the hydrogen side, the charge transfer of the reaction is given in the following equation:

Electric Charge: $\mathrm{Q}=\mathrm{nF} \eta_{\mathrm{H} 2}$,

where $\mathrm{n}$ is the number of electrons ( 2 in this case), F is the Faraday constant (96485 Coulombs/mol $\mathrm{e}^{-}$), and $\eta_{\mathrm{H} 2}$ is the number of hydrogen moles consumed.

\subsubsection{PEM Fuel Cell Hydrogen Consumption}

The current of the fuel cell is the charge transfer per unit of time and is represented by:

$$
\text { Current: } \quad \mathrm{I}=\mathrm{Q} / \mathrm{t}=\mathrm{nF} \eta_{\mathrm{H} 2} / \mathrm{t} .
$$

Thus the hydrogen flow rate can be calculated with:

$$
\begin{array}{ll}
\text { Hydrogen flow rate: } & \dot{\eta}_{H 2}=\frac{I}{n F}=\frac{P}{n V F}(\mathrm{~mol} / \mathrm{sec}), \\
\text { Hydrogen flow rate: } & \dot{m}_{H 2}=\frac{I}{n F M_{H 2}}=\frac{P}{n V F M_{H 2}}(\mathrm{~g} / \mathrm{sec}),
\end{array}
$$

where $\mathrm{M}_{\mathrm{H} 2}$ is the molecular weight of hydrogen $(2.02 \mathrm{~g} / \mathrm{mol})$ [1].

\subsubsection{PEM Fuel Cell Hydrogen Supply}

Because not all of the fuel electrochemical reacts in the fuel cell, the fuel utilization value $\phi$ is less than $100 \%$. This value is typically above $90 \%$ in well-designed fuel cells when using high purity hydrogen. Thus the necessary hydrogen supply [1] is given by:

Required Hydrogen flow rate: $\dot{m}_{H 2}^{\text {sup }}=\frac{\dot{m}_{H 2}}{\phi}(\mathrm{g} / \mathrm{sec})$. 


\subsection{Control System}

The basic concerns in controlling the fuel cell include inputting the required amount of fuel and air, maintaining the optimal cell temperature, and maintaining the required internal pressures of the fuel cell at optimal levels for maximum performance. One of the main causes of inefficiency in fuel cells is the unnecessary fuel consumption with the fuel air flows (losing up to $25 \%$ of the stack power [5]) so it is important for the controller to let in exactly the correct amount of reactants. Improper control of the fuel cell causes not only inefficiency, but can also cause degradation within the cell to occur decreasing its performance over time.

The fuel enters into the anode side of the cell from a compressor through a simple valve. Air or oxygen can be allowed free-flow into the stack or can also be entered through a compressor. For dead-ended stacks, it is also necessary to control the purging used to eliminate contaminants and excess water and maintain the pressure.

The temperature is generally controlled through a fan or other cooling unit. Some fuel cells also have an external humidifier to maintain the humidity within the cell. The following sections describe some of the different methods that have been researched to efficiently control the PEM fuel cell.

\subsubsection{Controlling the Stack}

The method described in [5] uses adaptive techniques with the lookup tables to effectively control the fuel cell and ensure better performance even if aging deteriorates the fuel cell's efficiency. The lookup tables are based upon experimental results and often used to determine the required air flows. However, such controls alone cannot account for changes in the cell performance over long periods of time due to uncertainties and parametric drifts. By adding the adaptive Perturb and Observe (P\&O) technique on the inlet compressor and/or the backpressure valve, this method can control the pressure inside the stack, improving the performance over that of the methods based only on the tables. This robust technique is easy to implement and allows continuous searching for the optimal conditions of any performance level in a dynamic system.

Another controller, described in [6], dynamically maintains the reactant input to compensate when loads connected to the stack unbalance the electron equilibrium. The 
controller monitors the stack temperature and current with an averaging filter to reduce high frequency noise in the measurements. It makes the necessary calculations and outputs the signals to control the fan speed and oxygen input valve, while the hydrogen flow is determined using a proportional pressure valve. By maintaining the stack temperature and air flow at the optimal levels, the controller can achieve higher efficiencies [7].

A Fuzzy feedback controller [8] has also been developed to maintain the complex internal processes of miniaturized fuel cell systems, which do not have room for external cooling or humidification equipment. Fuzzy Logic could handle the internal feedback system without requiring an analytical process model. The controller was developed by translating the operation of the fuel cell stacks into a structural system approach and then optimizing with measured process data [9]. These controllers effectively increased the performance and lifetime of the fuel cell stacks.

The power management is important in controlling the power output of the stack. As mentioned before, the output needs to be constant and stable to prevent possible damage to the stack or the load. Stack current fluctuations can cause degradation of voltage variation, oxygen starvation, disturbance in the anode and cathode pressure, membrane dry-out, and voltage reversal [8]. When the current sharply increases, more fuel and air is immediately needed, but if the mechanical equipment is too slow, it could cause oxygen starvation. It can also cause the electroosmatic drag to remove the water from the anode faster than back-diffusion can replace it with water from the cathode, which can lead to drying out the anode and possibly voltage reversal. When it decreases sharply, it can lead to air loss and possibly damage the cell membrane.

A method that was developed to control the power output while taking into account the load fluctuations [8] uses a current and voltage sensor, a DC/DC module, an electronic controller, and a Linear Quadratic Regulator (LQR) algorithm to provide a constant load with a stable current. This controller regulates the charging or discharging current according to any load changes insulating the fuel cell from its load. The diagram of this system can be seen in Figure 3. 


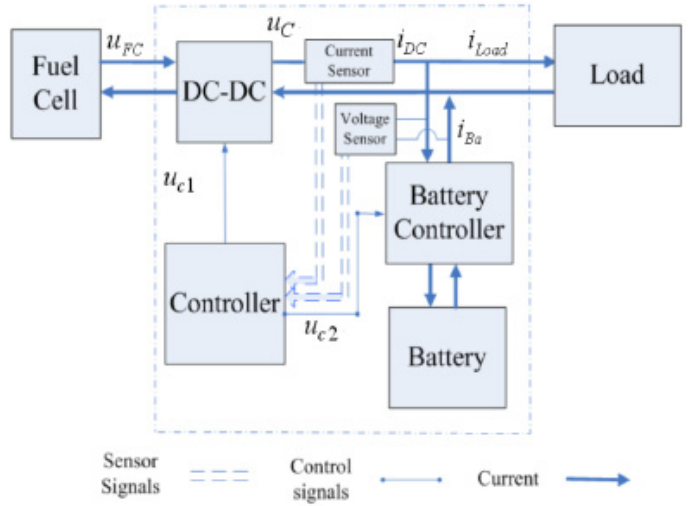

Figure 3: Power Management System accounting for load fluctuations [8]

The system includes two closed loops: one that regulates the output voltage into an expected range and one that regulates the charging and discharging of the battery, stabilizing the stack current whenever the loads fluctuate. These loops need to be synchronized with the LQR algorithm controlling the charging and discharging of the battery. When tested, the method was effective in reducing the effects of load fluctuations.

\subsubsection{Water Management}

When water is formed as a result of the electrochemical reactions of the PEM fuel cell, it either needs to be removed through the gas channel or moved from the cathode to the anode. Because the cell temperature is well below water's boiling point, the liquid water could remain in the gas channels affecting the mass-transport resistance and if the membrane dries then the ohmic resistance of the fuel cell would increase. A model [9] exists to study the water flow, both in vapor and liquid form, through the fuel cell. Lower reactant utilization and higher pressure drop in the reactant streams are optimal for good water management in the stack, but the higher reactant utilization and lower pressure drop make for better overall efficiency and water balance. An intracell water-exchange method using a fine-pore water transport plate was developed to provide humidification and water recovery without relying on external equipment. It creates a pressure difference between the reactants and coolant that removes the water, creating a better 
performance with high reactant utilization and high limiting current at low reactant pressure [9].

Another method involves using electroosmotic pumping structures to remove the excess water while consuming only a small amount of power. The pumping structures have no moving parts, can scale with the fuel cell, and have a wide range of operating conditions. A design using the electroosmotic pumps was developed and shown to improve the mass transfer limitations in the cathode and prevent cathode flooding. This should allow the fuel cells to be used in lower temperatures and high humidity and to reduce the loads required for the air compressors [10].

\subsubsection{Gas Management}

The water formed during the PEM fuel cell operation or supplied by a humidification system is necessary to the fuel cell's efficiency but can be detrimental by blocking the reactants and creating mass transport limitations [11]. The excess water is usually removed by purging the airflow, because the cells in a stack are generally fed in parallel, and the water can cause a blockage of that airflow. Since the flow needed to remove the excess water is steadily decreasing, this creates an ever increasing problem. This could drive a cell to voltage reversal if starvation of the reactants occurs.

Methods ensuring equal gas distribution often include flow fields designed for high-pressure drops or high stoichiometric flow rates. The pressure drop through the flow field plates minimizes any pressure drops caused by the water. Unfortunately, pressurizing the air costs a significant amount of power. Another method is to purge individual or groups of cells to ensure proper water management. Such an active gas management (AGM) system was shown to improve the power output by $30 \%$ [11]. This system can compensate for unequal flow path resistance and will not allow the resistance to build up over time.

Another method currently being developed integrates the flow distribution for individual cells within the stack using microelectromechanical systems (MEMS) to provide microvalves for internal flow control. This technology costs only a fraction of the conventional valves and could vastly increase the lifespan of the cell stack in the future [12]. 


\subsubsection{Thermal Management}

Thermal management is needed to maintain the PEM fuel cell stack at its optimal temperature. In efforts to reduce the size required by the fuel cell system, a method was developed that cools the stack by transferring the heat using bipolar plates and distributing it to external cooling devices. This allowed the system to operate with fewer external components. This method was used to replace a lithium-ion battery and included thermal coupling of the hydrogen storage container and the stack with heat sinks connected on the sides where the thermal conductivity was highest [13].

\subsection{Hybrid Systems}

Hybrid systems often allow fuel cells to achieve better efficiencies and performance by allowing other power sources to support the fuel cell stack, which can be weakened by sharp load changes. The fuel cell system usually require an external startup, but such power sources can also contribute to power peaks allowing for smaller stacks and avoiding severe conditions. Particularly in the automotive fields, hybrid systems allow for regenerative breaking, which can power the batteries by converting the kinetic energy of the vehicle [5].

\subsubsection{Fuel Cell/Battery}

The objective of the power management system designed for a fuel cell hybrid vehicle is to reduce the fuel consumption while maintaining the battery by requesting the desired current from the DC/DC module. The system has a supervisor controller (see Figure 4) to balance the fuel cell and battery power.

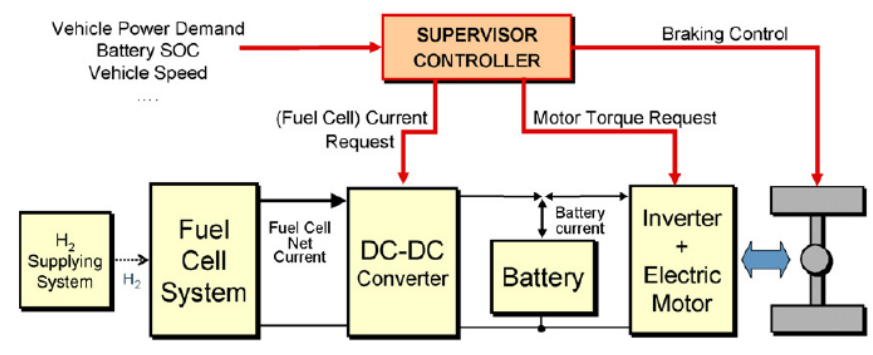

Figure 4: Fuel Cell Hybrid Vehicle System Diagram [14] 
The traditional method to manage the power output is to use rule-based methods, which are easy to understand but low in efficiency. Deterministic dynamic programming can theoretically achieve optimal fuel consumption, but as driving scenarios are so difficult to predict, this optimal level cannot actually be reached [14].

\subsubsection{Fuel Cell/Photovoltaic Cell}

A hybrid system using fuel cells with photovoltaic cells (also known as solar cells) was designed and simulated in [15]. Solar cell output power has different characteristics from the fuel cell, but the study determined that two-stages of converters would not be needed. Their system instead used a single converter to retrieve the maximum power from the photovoltaic cell and output the DC voltage. Both PI and Fuzzy Logic controllers were determined capable of regulating the voltage within the stated requirements, but the PI controller was reported more reliable and easier to implement. However, the system still requires adjustments in the case of environmental changes [15].

\subsubsection{Fuel Cell/Ultra-capacitors}

In an example of a hybrid fuel cell and ultra-capacitor system, a project to develop an electric utility vehicle [16], the developers used the PEM fuel cell as the primary power source with an energy storage system consisting of ultracapacitors for the large transient loads (shown in Figure 5). The large transient loads were the significant problems in dealing with the fuel cell alone, as they significantly shortened the lifetime of the PEM fuel cell.

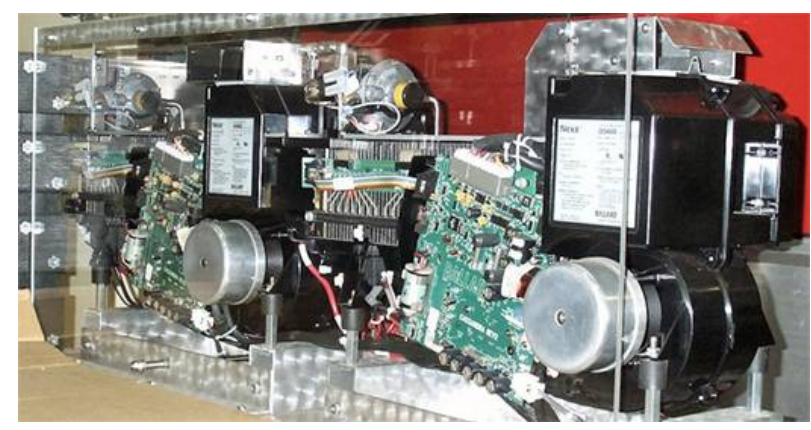

Figure 5: PEM Fuel Cell with Ultracapacitors [16] 
Ultracapacitors are a good choice because of their long lifetime, low maintenance requirement, and low operating temperatures. They were interconnected with the fuel cell to minimize the interconnection impedance, and together they provided ample energy and current density. Their system also employs the regenerative breaking to conserve power in the ultracapacitors that would otherwise be wasted during deceleration.

\subsection{Fuel Processing}

\subsubsection{Hydrogen Processors}

Another important concern in developing a fuel cell system is how to fuel the system. As hydrogen is not always the most viable fuel in terms of storage, fuel processors are often employed to transform liquid or even solid fuels such as diesel, natural gas, or coal into hydrogen or a reformate that can feed the fuel cell. Although the most popular method of hydrogen production is steam reforming of natural gas [17], this is not an optimal method for small or medium sized applications as it requires high temperature and high-pressure operation. The following describe some of the available fuel processors that could potentially work well with a portable PEM fuel cell.

\subsubsection{Commercial Fuel Processors}

\section{Innovagen Fuel Processor}

The Innovagen Fuel Processor (shown in Figure 6) can use renewable liquid fuels, such as alcohol and biodiesel; or carbon-based fuels, such as natural gas and gasoline. Because the PEM fuel cell requires a high purity Hydrogen fuel, this processor requires a specialized membrane when used with the PEM fuel cell. With the specialized membrane, the processor can provide 12 liters/minute of pure, dry hydrogen, which is supposedly suitable for up to a $1 \mathrm{~kW}$ PEM Fuel Cell. 


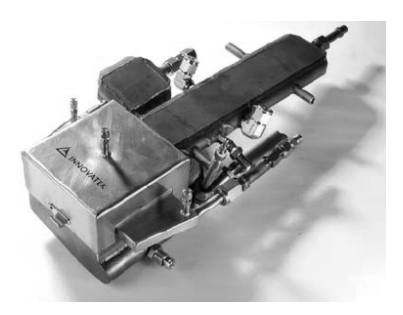

Figure 6: Innovagen Fuel Processor [18]

The relatively small processor includes an integrated micro channel reactor, a liquid fuel burner, a heat exchanger technology, and a fuel injector/atomizer that can eliminate coking. Additionally, the sulfur-tolerant steam reforming catalyst does not require sulfur removal from low-sulfur fuels [18].

\section{Compact Logistics Fuel Processor}

PCI's Compact Logistics Fuel Processor (shown in Figure 7) integrates efficient Auto Thermal Reformers (converting hydrocarbons into hydrogen through steam reforming), Partial Oxidation, and Water Gas Shift Reaction (converting the carbon monoxide produced into additional hydrogen) [19]. Initially developed for Navy shipboard power requirements, it is an ultra-compact fuel reformer and fuel reforming catalytic reactor [20].

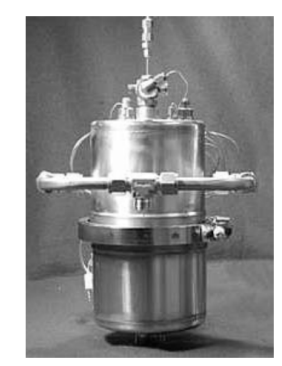

Figure 7: Compact Logistics Fuel Processor [19]

\section{HyPortable Portable Fuel Processor}

The HyPortable Portable Fuel Processor works by using planar metal membrane like a filter to extract hydrogen from hydrocarbon fuels. It can input several different types of liquid fuels, including natural gas, methane and propane. This compact and scaleable processor can provide high purity hydrogen $100 \mathrm{~W}$ to $1 \mathrm{~kW}$ fuel cells. It is said to be applicable for portable applications because of its low temperature operation and high durability [21]. 


\section{Ecotality Hydratus}

Ecotality's Hydratus method uses magnesium and water to produce hydrogen and steam. Reported to be environmentally safe, non-combustible, with a recyclable fuel source, this processor is planned to be incorporated into a demonstration fuel cell bus. However, this product will not be commercially available until, at earliest, 2008 [22].

\subsection{Hydrogen Storage}

As mentioned in the previous section, providing the necessary fuel for the fuel cell is a complicated issue. Instead of reforming fuels the system could store the hydrogen itself, but although hydrogen is the most abundant element and has high energy per mass, as a gas it is much harder to store than liquid fuels. The traditional method used by most fuel cell car prototypes is using a high-pressured tank. Unfortunately, these tanks are still very bulky and as they have a highly compressed flammable gas can also prove to be very dangerous [23]. Another option is to store the hydrogen in its liquid state in super-cooled tanks. The cooling increases its density, but also needs a significant amount of power to cool the hydrogen when storing and then heating it back to its gaseous state for fueling.

A promising technology that overcomes these problems is the metal hydride storage tanks (as used in this study). The hydrogen can be stored in a solid alloy that can absorb the hydrogen and form hydrides. Such containers can hold significant amounts of hydrogen, but they still prove to be very heavy and can require high temperatures to get the hydrogen back out [23].

Another new technology still being researched involves carbon nanotubes. Although the nanotubes alone can only store the hydrogen at very low temperatures, by adding in metals they could absorb the hydrogen at higher temperatures. However, this technology is still proving to be extremely expensive, especially as the most common metal added is platinum [23]. Another promising material is graphite or coal, which are much less expensive, non-toxic, easily prepared, and can store hydrogen well at room temperatures and pressures. Research is currently being done to work on graphite nanostructures that could store the hydrogen between nanometer deep graphite that could also keep out contaminants [24]. 


\section{Chapter 3: $\quad$ Fuel Cell Control System}

\subsection{Introduction}

This chapter evaluates the efficiency of two $100 \mathrm{~W}$ convection PEM fuel cells by conducting a series of tests and data analysis on two commercially available fuel cells, the Jadoo [25] and the Horizon [26] fuel cells, and examining the effectiveness of each type's fuel and air management. By studying the key factors involved in the fuel cells' performance, they can be used to develop an optimally efficient control system for a PEM fuel cell stack.

While the construction level of the Horizon and Jadoo fuel cells are different, the type of fuel cell is the same. Both are dead-ended, air breathing PEM fuel cell stacks with self-regulated fluid control. The water produced as a byproduct is also used to keep the needed water in the electrolyte. Although the difference in construction leads to many differences in the performance of the stacks, the Horizon fuel cell is designed more for research purposes and allows for easier control of numerous variables that the consumer-designed Jadoo fuel cell has preprogrammed and thus difficult to manipulate.

\subsection{Jadoo Fuel Cell Description}

\subsubsection{Overview}

The Jadoo N-Gen (as shown in Figure 8), is a self-contained fuel cell unit rated to provide $100 \mathrm{~W}$ at its peak efficiency.

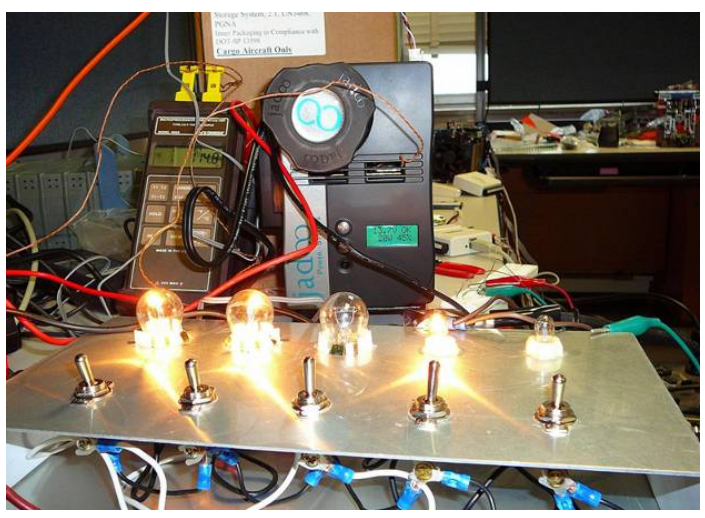

Figure 8: Original Image of Jadoo N-Gen connected to a variable light bulb bank 
The system is entirely automated, with a LED display that presents information on the:

- Power output,

- Output voltage,

- Hydrogen fuel rate,

- Fuel percentage,

- Time duration of operation, and

- System status.

The consumption of fuel value is determined entirely by calculation and is stored in the specially designed fuel cell canisters [27] used by the system. To operate the fuel cell, the user inserts the Jadoo metal hydride hydrogen storage canister, which starts the system, and connects the fuel cell output to the load. The unit also came with a built in hydrogen sensor that would shut off the unit if the sensor detected dangerous levels of hydrogen indicating a leak in the system.

The specifications of the Jadoo fuel cell are shown below in Table 2, and storage tanks in Table 3.

Table 2: Jadoo Fuel Cell Specifications

\begin{tabular}{|l|l|}
\hline \multicolumn{1}{|c|}{ N-Gen Fuel Cell Power Unit [25] } & \multicolumn{1}{c|}{ Proton Exchange Membrane (PEM) } \\
\hline Gold Mount Output & $11.5-17.0 \mathrm{VDC}$ \\
\hline Side-Mounted 2-Pin Output & $11.5-14.5 \mathrm{VDC}$ \\
\hline Power & $100 \mathrm{~W}$ (continuous at $\left.90^{\circ} \mathrm{F}\right)$ \\
\hline Start-Up Time & $2 \mathrm{sec}($ maximum) \\
\hline Start-U and Steady-State Operation & Automatic \\
\hline Operating Temperatures & $35-100^{\circ} \mathrm{F}$ \\
\hline Operating Humidity & $10-100 \%$ RH \\
\hline User Interface & Bi-color status LED and LCD display \\
\hline Noise & $33-55$ dB \\
\hline Power Unit Size & $4.3^{\prime \prime}$ x $4.3^{\prime \prime}$ x 7.4” \\
\hline Power Unit Weight & $5.11 \mathrm{bs}$ \\
\hline Fuel Supply Hot Swap & Yes, with continuous power for 5 $-30 \mathrm{sec}$ \\
\hline Fuel Leak Detection and Control & Yes, with integrated fuel shut-off valve \\
\hline Over-Current Protection & Yes, with auto-reset on load disconnect \\
\hline Over-Temperature Protection & Yes, with auto-reset after cooling \\
\hline Listed Price & \$999.00 \\
\hline
\end{tabular}


Table 3: Jadoo Fuel Canister Specifications

\begin{tabular}{|l|l|}
\hline N-Stor360 [27] & Metal Hydride Hydrogen Canister \\
\hline Power Capacity & $360 \mathrm{~W}-\mathrm{h} / 30 \mathrm{~A}-\mathrm{h}$ \\
\hline Weight & $5.1 \mathrm{lb}$ \\
\hline Size & $2.5 \%$ X 10.5” (dia. X length) \\
\hline Refill Method & Jadoo Refill Station \\
\hline Listed Price & $\$ 849.00$ \\
\hline N-Stor130 [27] & Metal Hydride Hydrogen Canister \\
\hline Power Capacity & $130 \mathrm{~W}-\mathrm{h} / 10$ A-h \\
\hline Weight & $2 \mathrm{lb}$ \\
\hline Size & $2.5 ”$ X 4.5” (dia. X length) \\
\hline Refill Method & Jadoo Refill Station \\
\hline Listed Price & \$449.00 \\
\hline
\end{tabular}

\subsubsection{Control Unit}

The unit has a built in controller (Figure 9) that is started using a 9-volt battery and then powered by current drawn from the stack.

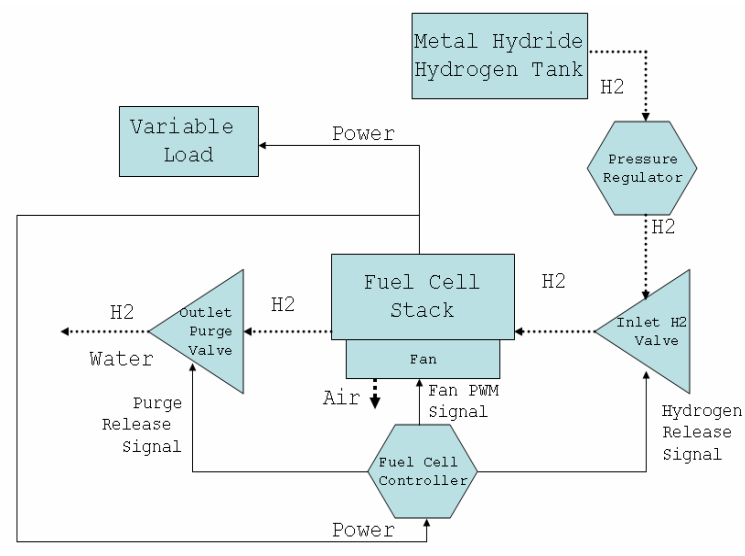

Figure 9: Jadoo System Setup

The controller monitors the voltage at every five cells in the stack, the overall stack temperature, and the overall output current; and generates:

- The pulse width modulated (PWM) fan signal, as regulated by the stack temperature;

- The signal to the hydrogen solenoid (Figure 10), which remains high while the fuel cell is on; 


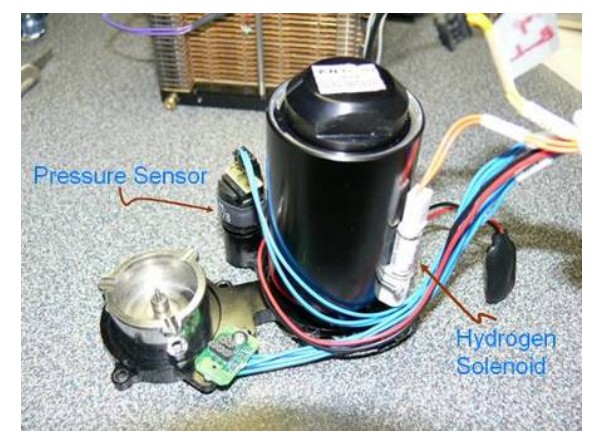

Figure 10: Jadoo Hydrogen regulator and solenoid

- The signal to the purging solenoid (Figure 11), which opens up the anode outlet of the stack briefly to expel any contaminants and regulate the stack pressure. The purging is set to occur in two small .16-second bursts every 20 minutes or at voltage drops of greater than 0.5 volts.

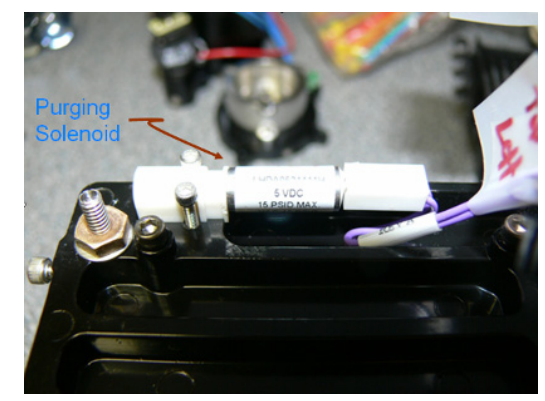

Figure 11: Jadoo Purging Solenoid

\subsubsection{Operation}

The sequence of events of the system startup is shown in Figure 12. As soon as the fuel canister is connected, the control unit is turned on powered by the 9-volt battery. The controller reads in the fuel percentage data stored in the canister's circuitry, and if there is sufficient fuel and pressure will begin by opening the hydrogen valve while simultaneously purging the system. This initial purge eliminates any contaminants that might remain in the stack and lasts twice as long as the purges that take place periodically during operation. The controller is powered by the stack as soon as the stack is capable of providing sufficient power. 

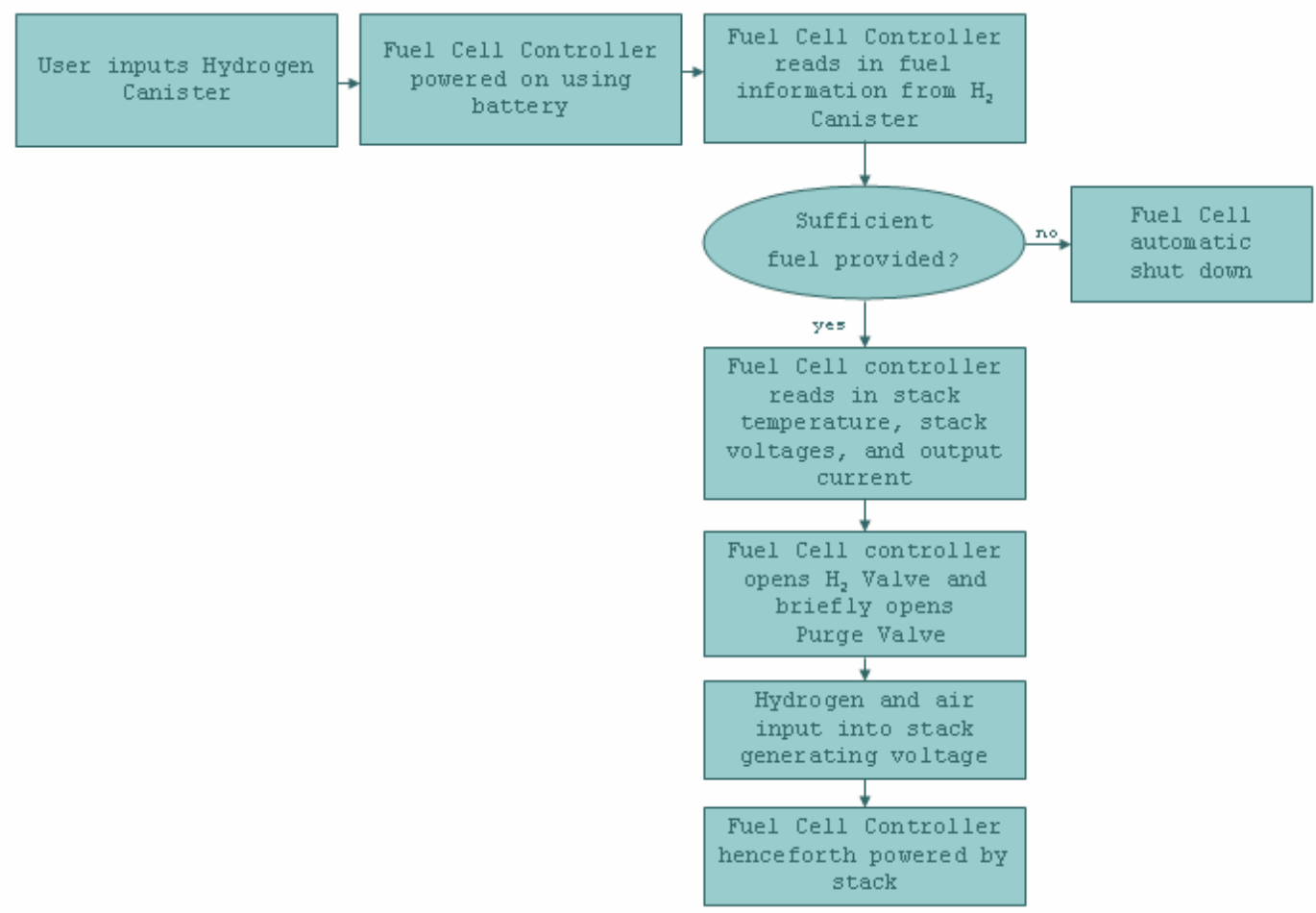

Figure 12: Flowchart of Events During Jadoo System Start-u p

The sequence of normal operation after startup is shown in Figure 13. The controller continuously monitors the voltage at every five layers of the stack, the overall current output, and the stack's temperature. The controller will automatically shut off the fuel cell if there is a current overload and can allow the stack to reach powers up to $130 \mathrm{~W}$. The fuel cell will also shut down if there is insufficient fuel or the fuel canisters pressure is too low. The canisters will drop drastically in temperature, which can sometimes cause the internal pressure to drop enough that a low pressure warning will be given even if the canister contains fuel. The canister can often resume operation if allowed to return to room temperature. 


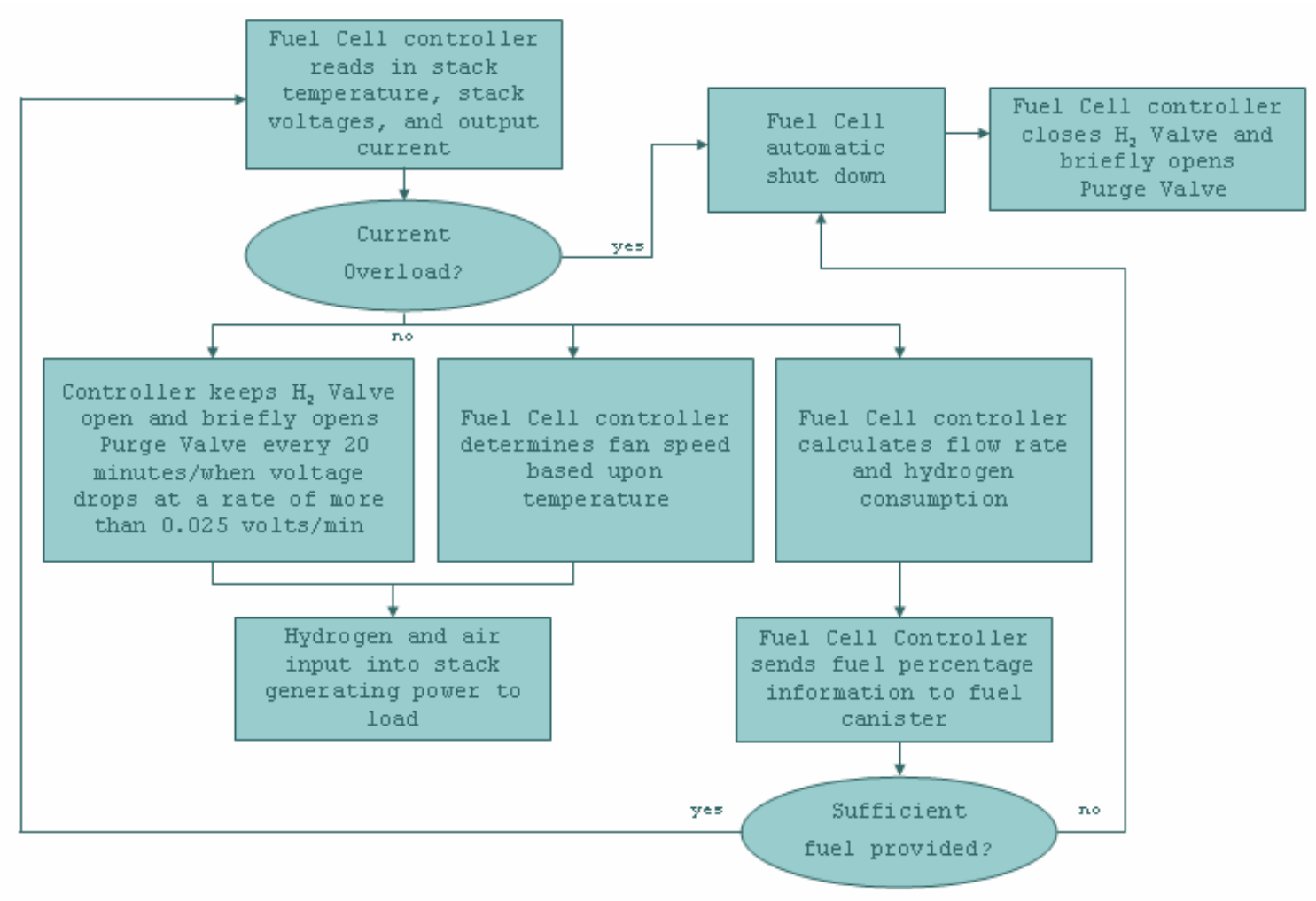

Figure 13: Flowchart of Events during Jadoo Operation

The controller keeps the hydrogen valve open until the unit is turned off, either automatically or manually. The purging valve is opened to purge the stack every 20 minutes or if the voltage drops at a faster rate than $0.025 \mathrm{~V} / \mathrm{min}$, and this helps restores the fuel cell's performance to its maximum level. The output power automatically adjusts to the load requirement. The fan is controlled as a ratio to the temperature of the stack and at very low power outputs of below $20 \mathrm{~W}$, which generate very little heat, the fan will not turn on at all. The controller keeps track of the power output and time, and uses this information to calculate the hydrogen flow rate and consumption. The amount of hydrogen remaining in the canister is calculated and stored in the fuel canister's circuitry.

When the system shuts down, the controller will cease providing any external power, but does remain on to use whatever hydrogen remains in the system to display a message to the user asking to insert a filled canister. It immediately shuts the hydrogen valve, and briefly opens the purge valve to purge the system of any hydrogen left in the stack. 


\subsection{Horizon Fuel Cell Description}

\subsubsection{Overview}

The Horizon fuel cell stack (Figure 14) is, like the Jadoo, an air-breathing convection fuel cell with dead-ended hydrogen purging rated to provide $100 \mathrm{~W}$ nominal power and $140 \mathrm{~W}$ maximum power. The optimal performance of the fuel cell was reported as $12 \mathrm{~V}$ at $8.5 \mathrm{~A}$. Unlike the Jadoo fuel cell stack, the Horizon fuel cell stack was designed more for the researcher than the consumer, and thus was less automated and allowed the user to control more variables. The fuel cell came with an optional externally powered controller, but left open the option for the user to develop and use their own controller to control the hydrogen input, purging, and fan speed.

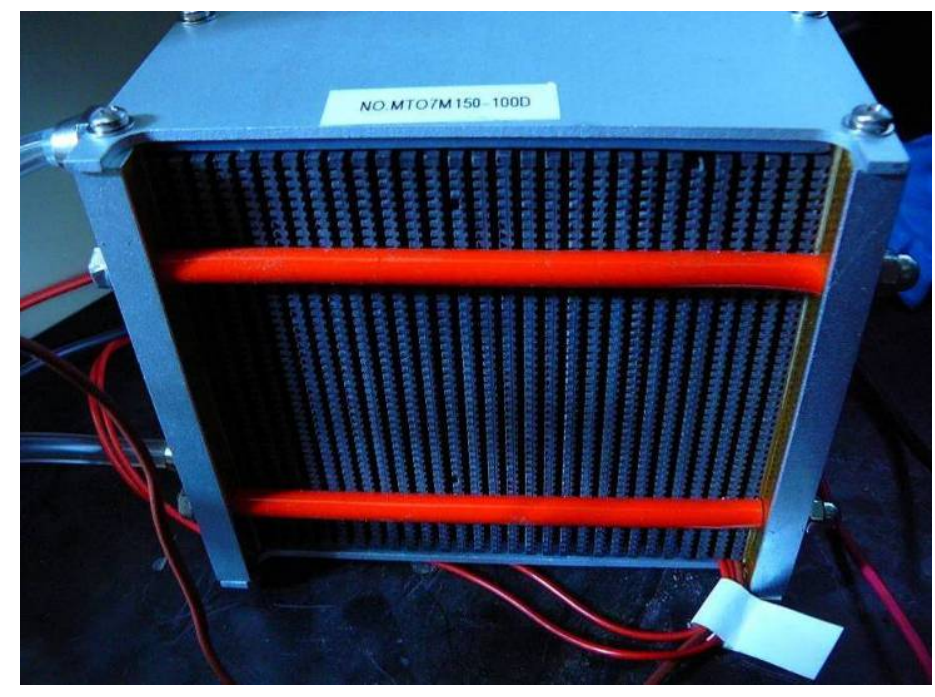

Figure 14: Horizon Fuel Cell Stack

The fuel to the cell was provided by an Ovonics metal hydride hydrogen tank, (shown in Figure 15). 


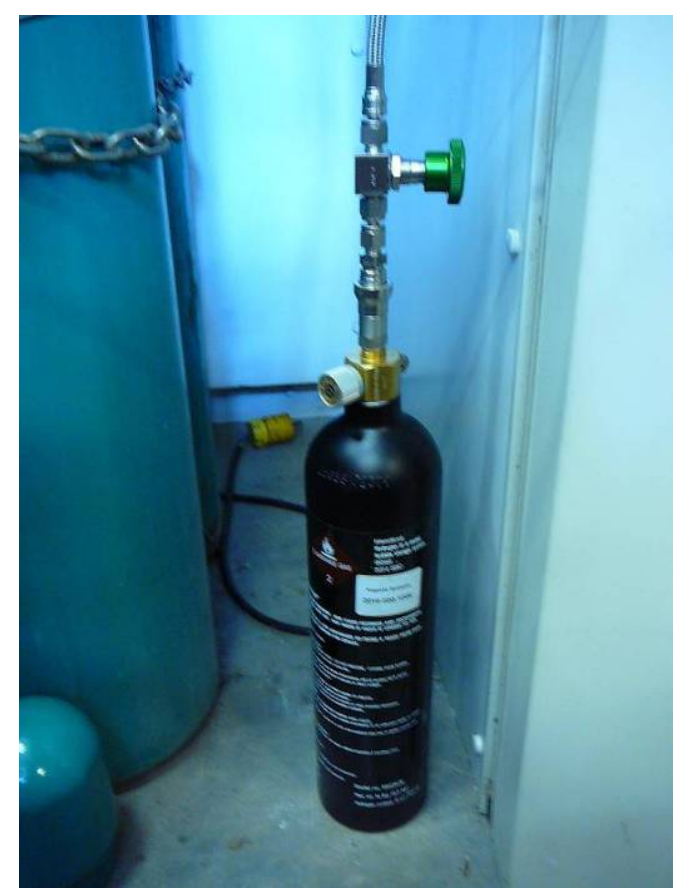

Figure 15: Metal Hydride Hydrogen Tank

The hydrogen input was controlled using a low pressure regulator, (shown in Figure 16).

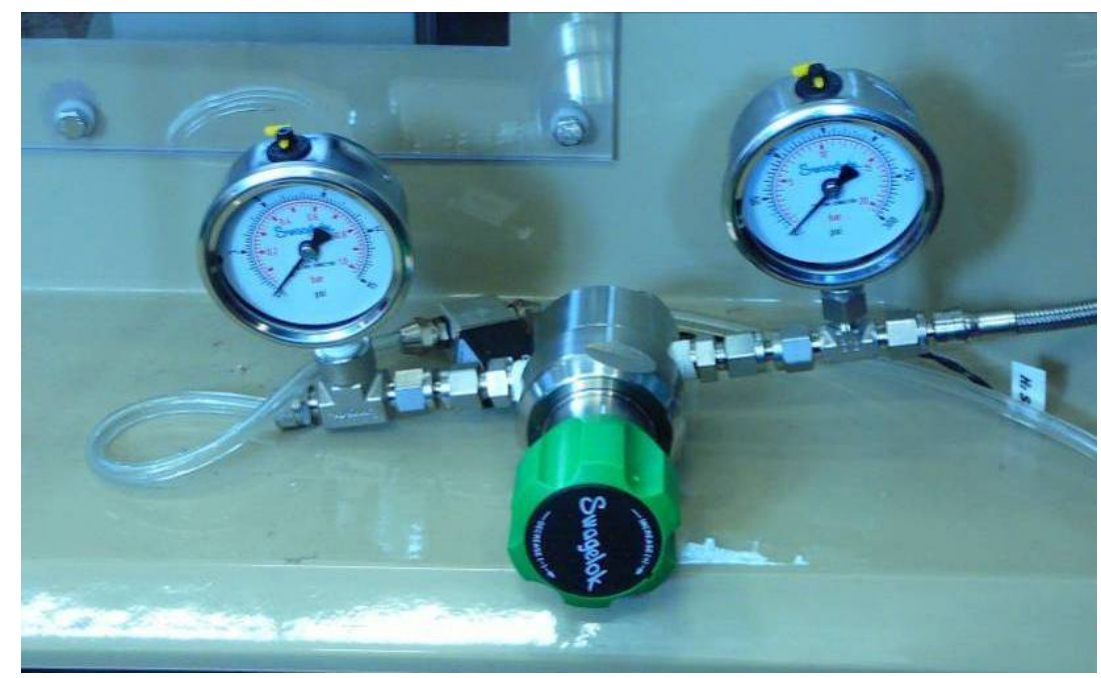

Figure 16: Low Pressure Gauge, Regulator, and High Pressure Gauge

This unit was also self-humidified, but unlike the Jadoo, which did not have any noticeable water output, the Horizon visibly released small amounts of water through the 
purging valve also responsible for releasing excess hydrogen, restoring the performance of the fuel cell.

The specifications of the Horizon fuel cell and the Ovonics tank are shown in Table 4Table 4: Horizon Specifications and Table 5 respectively.

Table 4: Horizon Specifications

\begin{tabular}{|l|l|}
\hline \multicolumn{1}{|c|}{ Horizon 100W Fuel Cell [26] } & \multicolumn{1}{c|}{ Proton Exchange Membrane (PEM) } \\
\hline Cell Number & 28 \\
\hline Nominal Power & $100 \mathrm{~W}$ \\
\hline Peak Power & $140 \mathrm{~W}$ \\
\hline Performance & $12 \mathrm{~V} @ 8.5 \mathrm{~A}$ \\
\hline Reactants & Hydrogen and Air \\
\hline Temperature & $5-65^{\circ} \mathrm{C}$ \\
\hline H2 Pressure & $2.9-4.25$ PSI \\
\hline Humidification & Self-humidified \\
\hline Cooling & Integrated cooling fan \\
\hline Weight (fan and casing included) & $1.6 \mathrm{~kg}$ \\
\hline Dimensions & $11.5 \mathrm{~cm} \times 11.5 \mathrm{~cm} \times 15.5 \mathrm{~cm}$ \\
\hline Flow rate at max output & $1.51 / \mathrm{min}$ \\
\hline Start up time & Immediate \\
\hline Efficiency of stack & $45 \% @ 12 \mathrm{~V}$ \\
\hline Listed Price & $\$ 1300.00$ \\
\hline
\end{tabular}

Table 5: Ovonics Hydrogen Canister Specifications

\begin{tabular}{|l|l|}
\hline \multicolumn{1}{|c|}{ Ovonics [28] } & \multicolumn{1}{c|}{ Metal Hydride Hydrogen Canister } \\
\hline Diameter & $2.5 \mathrm{in}$ \\
\hline Length & $10.4 \mathrm{in}$. \\
\hline Weight & $4.8 \mathrm{lbs}$. \\
\hline Nominal Capacity & $225 \mathrm{std}$. liters \\
\hline Nominal Discharge Rate & $300 \mathrm{~W}$ \\
\hline Listed Price & $\$ 525.00$ \\
\hline
\end{tabular}

\subsubsection{Horizon Control Unit}

The Horizon fuel cell stack came with an optional control unit, (shown in Figure 17), which monitors the temperature and overall voltage output; and output signals to the PWM fan speed, the hydrogen inlet solenoid, and the purging solenoid. 


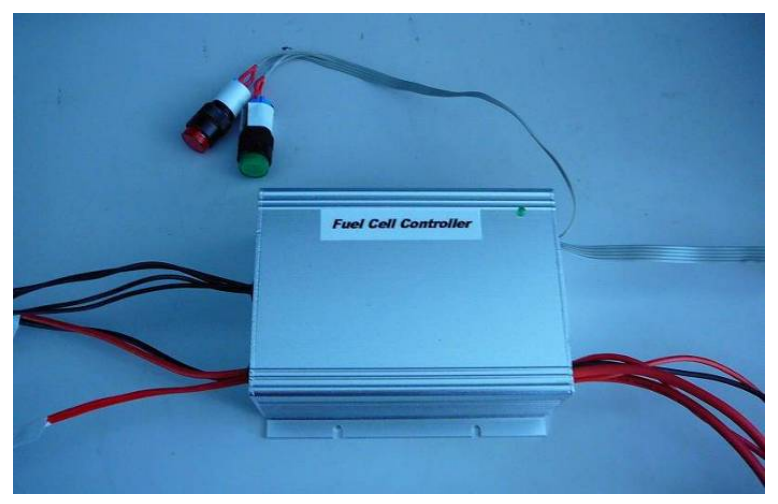

Figure 17: Original Horizon Fuel Cell Controller

The system setup (shown in Figure 18) diagrams the inputs and outputs of the Horizon fuel cell's operation with its controller. The fan was controlled as a direct relationship with the temperature and increased in speed as the stack temperature increased. The hydrogen inlet valve remained open as long as the pressure to the fuel cell was sufficient, and the purging solenoid was timed to open every 10 seconds and last .7 seconds, regardless of the load or operating conditions of the cell. The control system also requires a separate 13-volt power supply, as pictured in Figure 18.

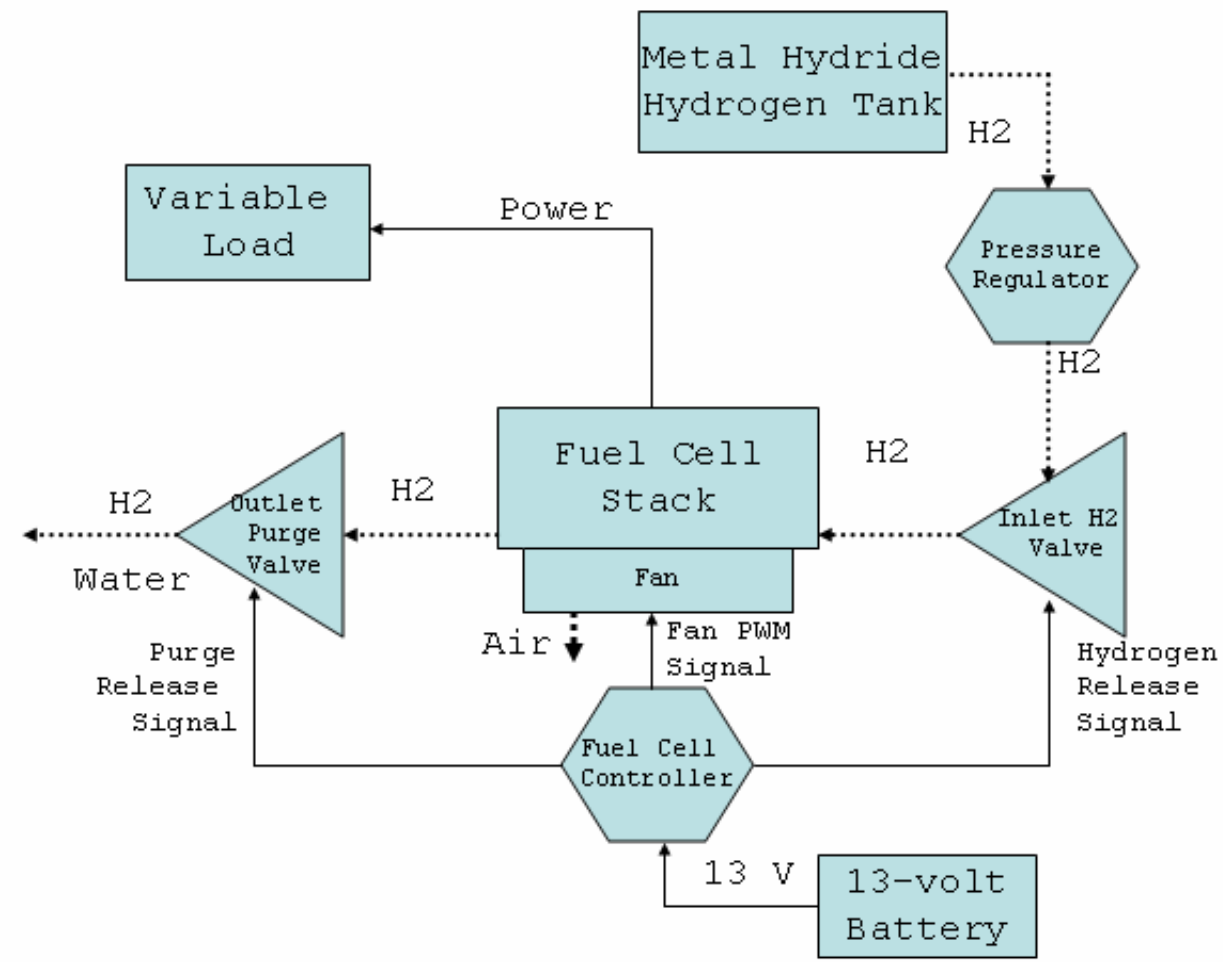

Figure 18: Horizon System Setup 


\subsubsection{Operation with Horizon Control Unit}

For the fuel cell to run using the controller it was necessary to maintain the inlet pressure above 3 PSI or the controller would automatically turn off. Therefore, careful adjustments of the fuel cell are required to control the inlet pressure. During normal operation of the fuel cell using the provided fuel cell controller, the pressure briefly dropped before returning to its previous value whenever the system was purged. The pressure also changed dependent on the load; with higher loads decreasing the pressure because of the necessary increase in the hydrogen consumption rate. Excess water was released into the outlet where the system is also purged of hydrogen.

In later experiments, this controller was replaced by a user-developed controller that allowed the user to control the fan speed and purging times. The Neodym HydroKnowz [29] hydrogen sensor was used to monitor any output of hydrogen and ensure safety. The sensor was particularly used to monitor the hydrogen released from leaks in the stack and from the purging valve. The purging valve and hydrogen sensor are both shown in Figure 19.

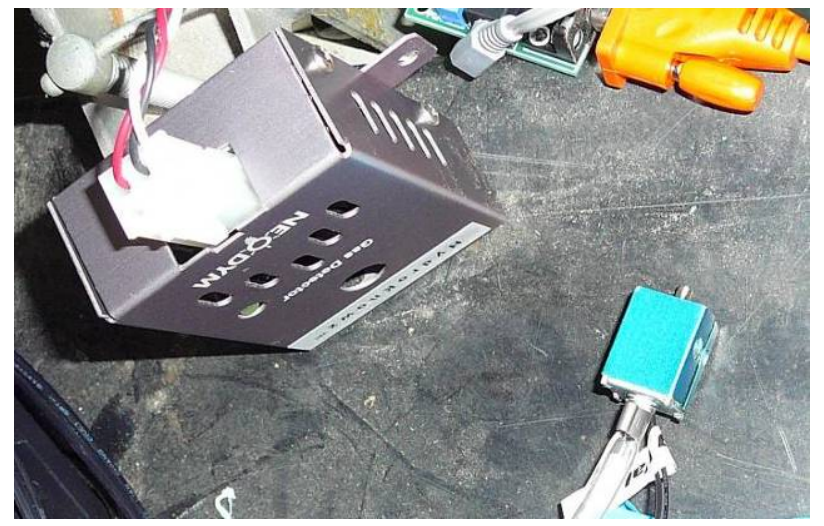

Figure 19: Hydrogen sensor and purging valve

The control system also often short-circuited the stack to maintain its performance, but with the added affect of briefly dropping the voltage to zero, as shown in Figure 20. In the graph, the red signal represents the hydrogen solenoid, the green signal represents the purging solenoid, and the blue signal represents the voltage. 


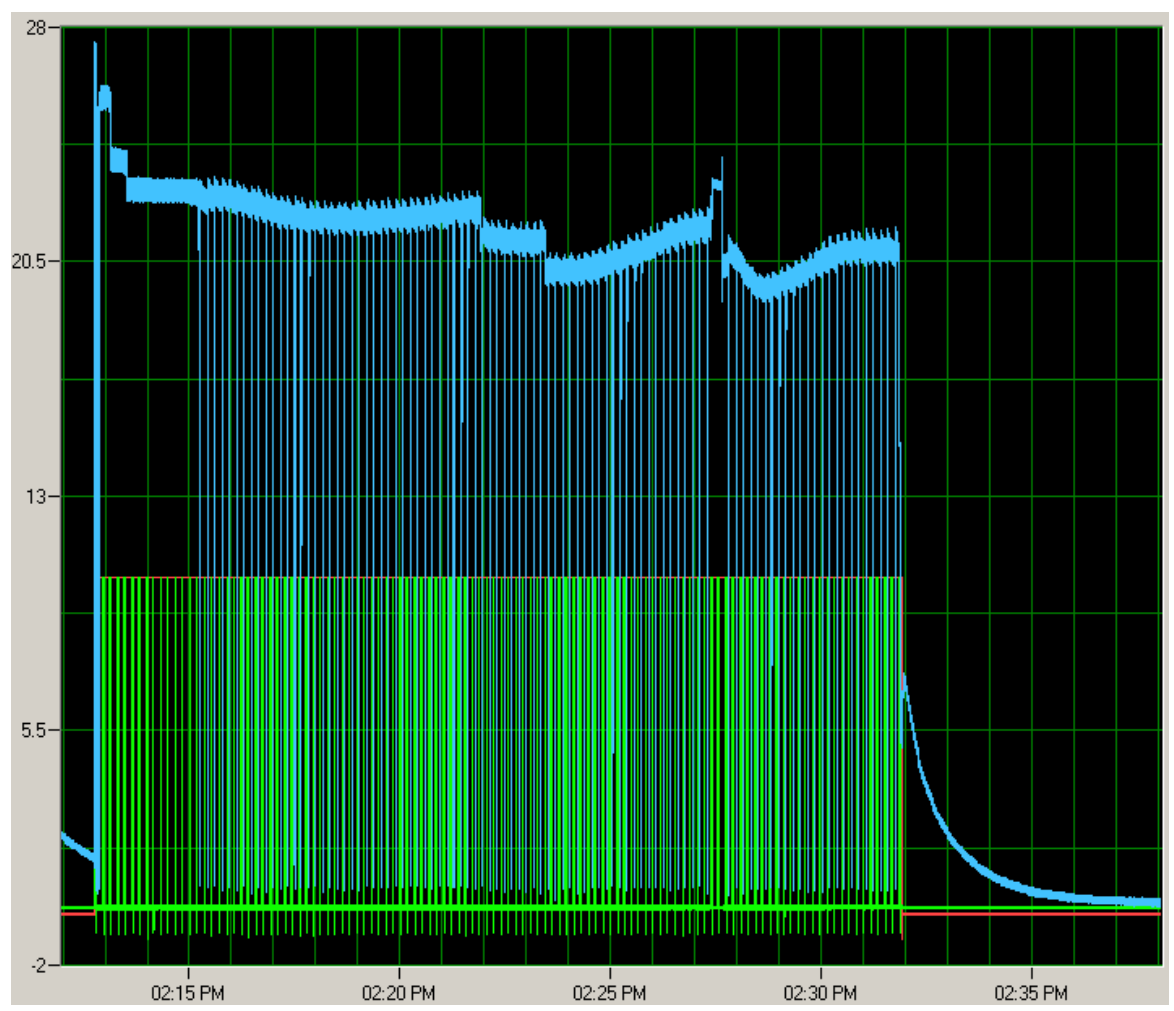

Figure 20: Voltage and solenoid signals of Horizon Fuel Cell

In every test, the fuel cell had to first be run without a load until it achieved its maximum open circuit voltage, or the power achieved would be significantly lower and often keeps the fuel cell running at below $11 \mathrm{~V}$.

\subsubsection{User-Created Control Unit}

To control other factors affecting the fuel cell such as the fan speed or purging, it was determined that a controller be developed that would also allow the user to control the fan speed and purge times. This new controller was developed in Labview and designed to work with National Instruments USB 6009 [30]. The graphical user interface is shown in Figure 21. The graph on the right outputs in the voltage, input and output solenoids, and the fan, and the slide variable on the left controls the fan speed. 


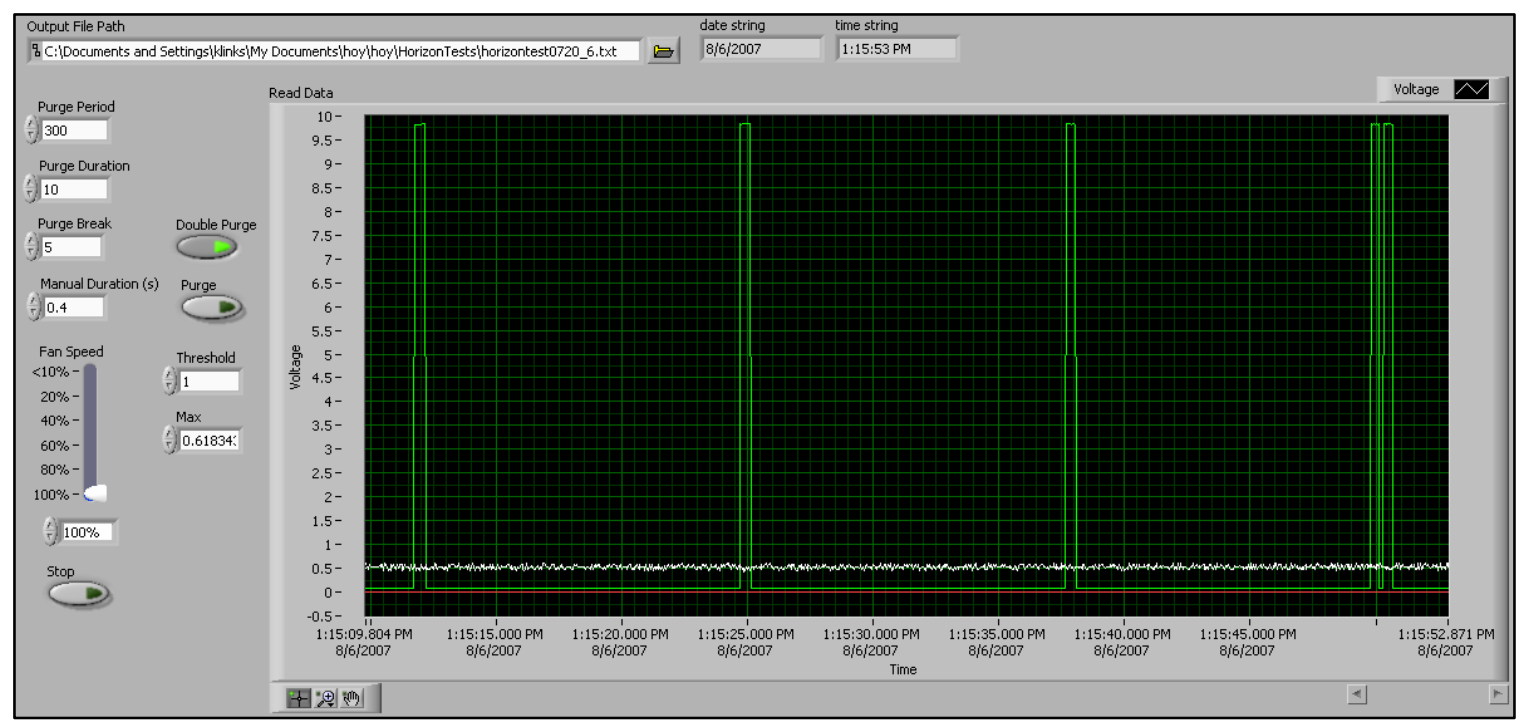

Figure 21: Control interface for the Horizon fuel cell stack

The new controller (block diagram shown in Figure 22) was responsible for monitoring and displaying the output voltage, and allowed the user to set the fan speed directly and control the purging valve.

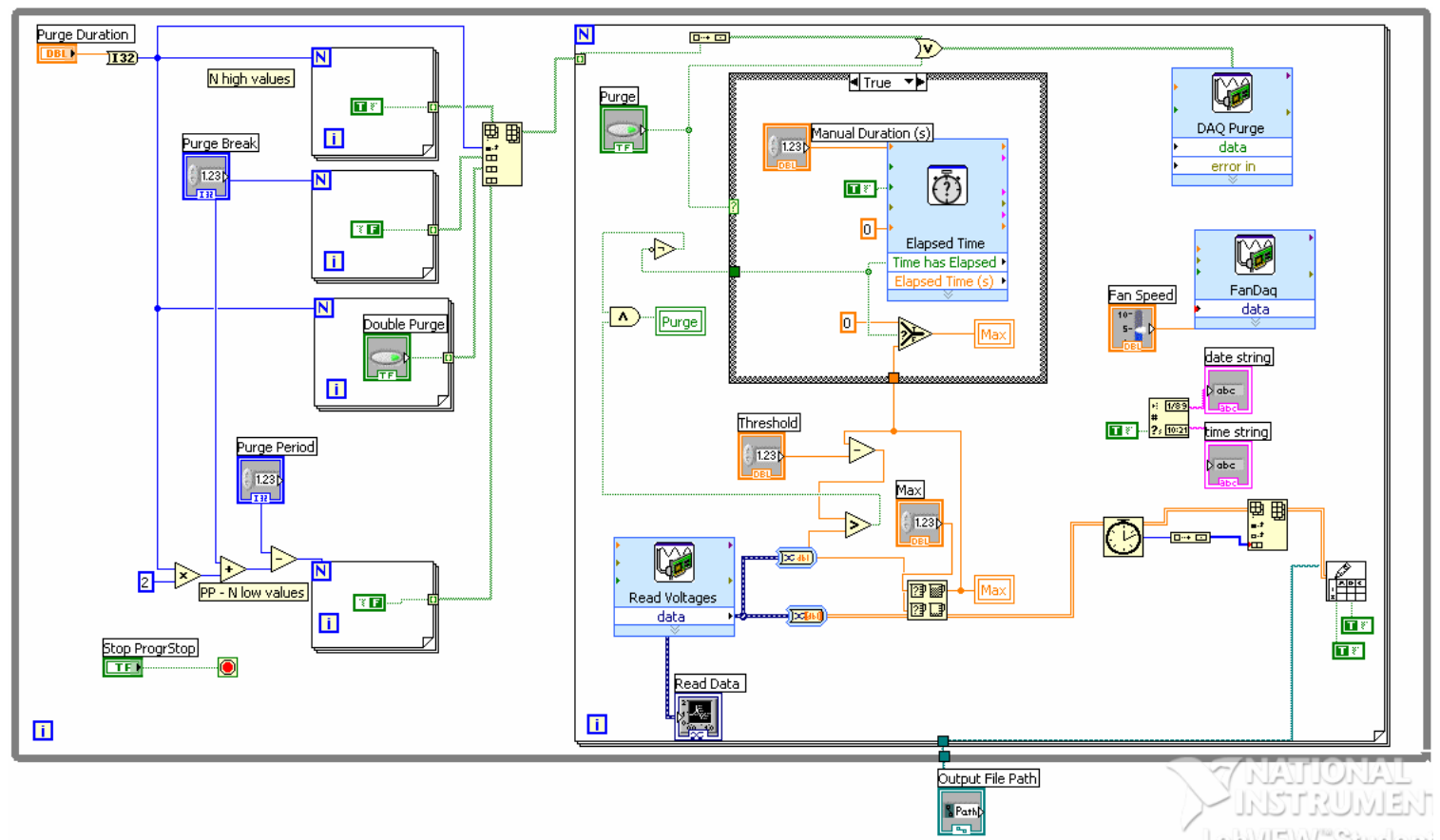

Figure 22: User-created controller Labview block diagram

The types of purging offered by the new controller are as follows: 
- periodic purging: would purge the system for the specified duration and period,

- timed manual purging: would allow the user to purge for a set period of time whenever the button was pressed,

- double purging: would purge in two timed bursts, and

- threshold purging: would purge whenever the voltage fell by a user-set threshold.

The timed manual purging was used to understand how the stack would react for short and long purges set at different times. The double purging was tested, but ultimately found to have little affect on performance. Ultimately, the most successful method of purging that provided the most stable performance for the least hydrogen lost was the threshold purging. The threshold was set for $.4 \mathrm{~V}$, and the purges would be as small as possible for minimum hydrogen loss.

As laid out in Figure 23, the new controller allowed the user to set the fan speed and use the three different types of purges either in conjunction or alone. The user can press the button for the manual purge, specify a cycle to purge each period, and/or to purge every time the voltage drops below a specified threshold. The user could specify the duration for each purge. The program displayed the real-time information of the voltage readings and purge signals, and output the information into a specified excel sheet.

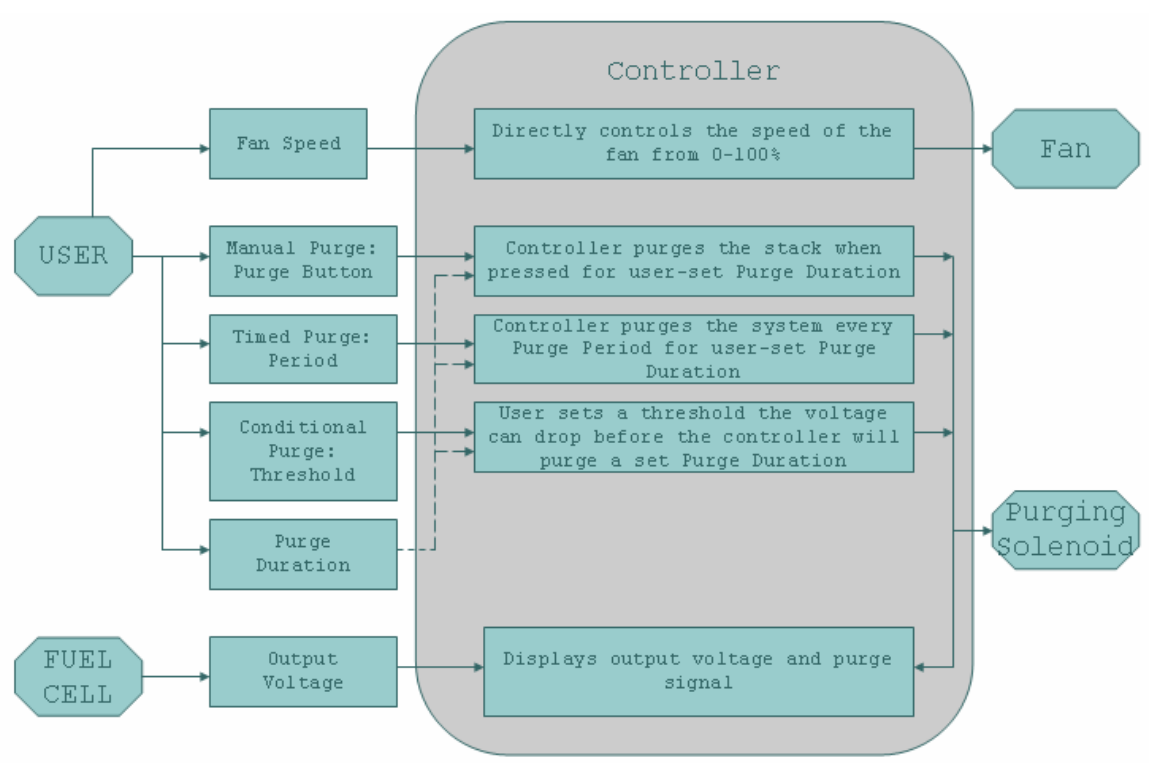

Figure 23: User-created controller functionality diagram 


\subsubsection{Operation with the User-Created Control Unit}

The User-created control unit gave the user more control over the stack, and also allowed the fuel cell to continue operation regardless of whether there was enough inlet pressure into the stack. It required constant supervision to ensure the inlet pressure did not go beyond or below acceptable levels. The controller also served to automatically record the voltage information and any fan and purging signals sent out.

\subsection{Testing Methodology}

\subsubsection{Data Acquisition}

In the performance and fuel consumption tests, the VI Logger worked with National Instruments device USB 6009 to collect and log the voltage(s) of the fuel cell stack, the solenoid signals, and the fan signal. The Fluke LH410 LEM AC/DC Clamp-on Ammeter [31] was used to accurately measure the current up to .01A precision. For the fuel consumption tests, to monitor the amount of fuel consumed, the mass of the hydrogen tanks was measured before and after each test using a Sartorius GP5202 Precision Balance [32]. The balance could measure up to 5200g at .01g precision, and was sufficient to measure the tanks used by the Jadoo (2.4kg max) and the Horizon (2.2kg max).

Both of the fuel cells were tested by connecting them to a variable load that consisted of a bank of light bulbs with a variable resistor bank. The variable load could be used to reach power outputs up to $250 \mathrm{~W}$. To judge the performance of the Jadoo fuel cell, the following information was collected at various loads:

- the voltage at every five cells of the stack $\{\mathrm{V} 1, \mathrm{~V} 2, \mathrm{~V} 3, \mathrm{~V} 4$ where V1 is the voltage of the $5^{\text {th }}$ cell and V4 the $\left.20^{\text {th }}\right\}$,

- the load current $\{$ I (Amps) $\}$,

- the pulse width modulated (PWM) fan signal $\{\mathrm{PWM}\}$,

- the outlet purging solenoid signal \{SignalOut\},

- the hydrogen inlet solenoid \{SignalIn\},

- the amount of time the fuel cell was run [t (sec)], and

- the mass of the fuel tank consumed during each run [g (grams)]. 
For the Horizon Fuel Cell only the overall stack voltage was measured. The temperature was measured with a thermocouple that was inserted into the stack. The high-pressure valve monitored the pressure of the hydrogen supply tank, and the lowpressure valve monitored the pressure after the regulator into the fuel cell hydrogen inlet solenoid.

The collected data of the Horizon fuel cell included the following:

- the inlet hydrogen pressure $\{$ PressureIn (PSI) $\}$,

- the hydrogen tank pressure \{PressureTank (PSI)\},

- the load current $\{\mathrm{I}(\mathrm{Amps})\}$,

- the stack voltage $\{\mathrm{V}$ (Volts) $\}$,

- the outlet purging times $\{$ SignalOut\}

- the fan speed $\{\mathrm{f}(\%)\}$,

- the stack temperature $\{\mathrm{t}($ Celsius $)\}$

\subsubsection{Determining the I-V Curve}

One of the most necessary pieces of information to collect in order to evaluate each fuel cell's performance is the polarization curve. From the I-V graph one can extrapolate several pieces of information such as the Tafel slope, a constant used in the Tafel equation typically used to calculate activation losses; the cell resistance, used to calculate the ohmic resistance losses; or the limiting current, used to determine the concentration losses. Basically, from observing the current-voltage characteristics of the fuel cell's performance, one can extrapolate the different types of losses the fuel cell undergoes at different loads.

The I-V curve of each fuel cell was determined by recording the output voltage of each fuel cell at increasing and decreasing currents. By measuring in both directions, one can tell if the water balance of the fuel cell is incorrect. If the curves do not match, but instead one is above the other, it could indicate the fuel cell is flooding or drying out. If there was too much water, then decreasing the current would cause less water to be produced and thus higher performance, and conversely if there was not enough then higher currents would produce more water and thus improve the performance. 


\subsubsection{Examining the Effect of Purging}

As previously stated, one of the important factors in maintaining a stable performance in the fuel cell relies on effective use of purging the dead-ended stack. To better understand how the fuel cells were making use of this control, both the Jadoo and Horizon control units were tapped into in order to observe how often and for what duration were they purging the system and what effect it appeared to have on the fuel cells' performance.

With the Jadoo fuel cell, the hydrogen solenoid could be unplugged and thus kept permanently dead-ended. This allowed for the performance of the fuel cell with and without its typical purging to be compared. The Horizon's new controller, which was designed to give more control over the parameters controlling the stack performance, was then used to alter methods of purging to better evaluate the effect. The timed purging was the system used by the original Horizon controller and altering the period and duration of the purges while monitoring the voltage, current, and pressure performance, allowed for better understanding of the effects of purging on the system.

\subsubsection{Monitoring the Flow Rate}

With the Jadoo fuel cell, one of the menu options was to reveal the flow rate of the ingoing hydrogen. This flow rate was monitored at different loads using the resister bank, and the equation used by the control system to evaluate the flow of hydrogen as a function of current could be extrapolated from the experimental data. With this information, the flow of hydrogen at different currents could be compared with the fuel rates measured in the next section.

The mass of hydrogen used for each test was measured and used to experimentally test the fuel cell's flow rate in grams per hour and moles per second:

Fuel Flow Rate $(\mathrm{g} / \mathrm{hr})=\mathrm{H}_{2}$ Used $(\mathrm{g}) /\{$ Time $(\mathrm{sec}) / 3600\}$

Fuel Flow Rate $(\mathrm{mol} / \mathrm{sec})=\mathrm{H}_{2}$ Used $(\mathrm{g}) /\left\{\right.$ Time $\left.[\mathrm{sec}] * M_{\mathrm{H} 2}(\mathrm{~g} / \mathrm{mol})\right\}$,

where $M_{H 2}$ is the molecular weight of hydrogen $(2.0158 \mathrm{~g} / \mathrm{mol})$. 
The actual rate that the fuel cell was consuming the hydrogen was calculated empirically as follows:

Fuel Consumption Rate $(\mathrm{mol} / \mathrm{sec})=\left\{\right.$ Current $\left.(A) * N_{\text {cell }}\right\} /\{n * F(\mathrm{col} / \mathrm{mol})\}$,

where the $N_{\text {cell }}$ is the number of cells (20), $n$ is the number of electrons involved in the transfer (2), and $F$ is Faraday's constant $(96487 \mathrm{col} / \mathrm{mol})$.

\subsubsection{Measuring the Fuel Efficiency}

By measuring each fuel cell's fuel consumption at different loads, it could be determined at what range the fuel cell used the hydrogen most efficiently. The fuel consumption tests used the precision balance to monitor the mass of the fuel canisters thus measuring the amount of fuel consumed. The mass was measured before, and after use of the canisters. It was assumed that the amount of hydrogen released when purging could be considered negligible.

The rate of the fuel input flow:

Fuel Flow Rate $(\mathrm{g} / \mathrm{hr})=\mathrm{H}_{2}$ Used $(\mathrm{g}) /($ Time $(\mathrm{sec}) / 3600)$.

Fuel Flow Rate $(\mathrm{mol} / \mathrm{sec})=\mathrm{H}_{2}$ Used $(\mathrm{g}) /\left(\right.$ Time $\left.(\mathrm{sec}) * M_{\mathrm{H} 2}(\mathrm{~g} / \mathrm{mol})\right)$.

The actual rate that the fuel cell was consuming the hydrogen was calculated as follows:

Fuel Consumption Rate $[\mathrm{mol} / \mathrm{sec}]=\left\{\right.$ Current $\left.(A) * N_{\text {cell }}\right) /(n * F(\mathrm{col} / \mathrm{mol})\}$,

where $n$ is the number of electrons involved in the transfer (2) and $F$ is Faraday's constant $(96487 \mathrm{col} / \mathrm{mol})$. The practical efficiency [2] of the fuel cell is the product of the fuel utilization efficiency, reversible thermodynamic efficiency, and voltage efficiency.

Efficiency (\%) = Fuel Efficiency * Thermal Efficiency * Voltage Efficiency 
The fuel utilization efficiency [2] describes how much of the hydrogen the fuel cell actually used to produce electrical power compared to how much hydrogen the fuel cell was supplied:

\section{Fuel Efficiency $(\%)=$ Fuel Consumed $(\mathrm{mol} / \mathrm{sec}) /$ Fuel Supplied $(\mathrm{mol} / \mathrm{sec})$}

The reversible thermodynamic efficiency [2] is the amount of energy the fuel cell can use to do work divided by the total energy of the system. Gibbs free energy is the term to describe the potential useable energy produced by the fuel cell and accounts energy received from the environment. Thus the reversible efficiency is described as:

Reversible Efficiency $(\%)=$ Gibbs free energy $(\mathrm{kJ} / \mathrm{mol}) /$ Reaction Enthalpy $(\mathrm{kJ} / \mathrm{mol})$

The voltage efficiency takes into account the losses experienced in the real operating voltage as compared to the thermodynamically reversible voltage of the fuel cell:

Voltage Efficiency $(\%)=$ Real operating voltage $(V) /$ Reversible voltage $(V)$.

The energy density of the fuel cell was calculated using the following equation of the measured values:

$$
\text { Energy Density }\left(W^{*} h / g\right)=\{\text { Power }(W) * \text { Time }(h r)\} / H_{2} \text { Consumed }(g)
$$

In order to fairly compare the results of the Horizon and Jadoo fuel cells, it was necessary to test them under the same conditions. Because the Horizon control unit was independently powered, while the Jadoo control unit was powered by the stack, more tests were performed to measure the power consumption of the Jadoo control unit so that the Jadoo results could be recalculated to account for the power lost to the control unit. With the Horizon configurable purging, one could also observe the effect purging had on the fuel efficiency of the fuel cell. 


\subsection{Battery Hybrid Implementation}

To prove the concept of a simple hybrid system and examine the fuel cell's operation when it was supplemented with another power source, a simple DC-DC converter was used to power a variable load from a battery and fuel cell combination (diagram shown in Figure 24). Earlier Section 2.4.1 describes the operation of a hybrid system utilizing a fuel cell and a battery using a DC-DC converter, and as shown, in the typical hybrid system there is a supervisor control to monitor over the fuel cell, battery, and $\mathrm{DC} / \mathrm{DC}$ device; but this experiment is designed more to study the performance between the converter and the fuel cell.

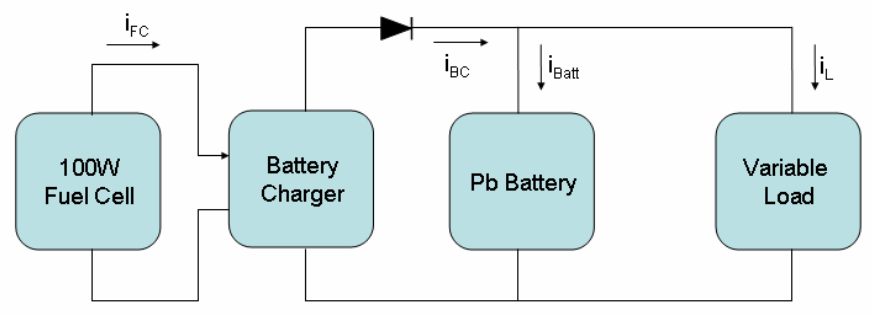

Figure 24: Fuel Cell/Battery Setup with Battery Charger

The battery used in the system was the rechargeable EaglePicher 12v7.2 sealed lead acid battery [33]. The specifications of the battery can be seen below in Table 6 .

Table 6: Battery Specifications

\begin{tabular}{|l|l|}
\hline Specifications & EaglePicher 12v7.2 \\
\hline Volts & $12 \mathrm{~V}$ \\
\hline mAh & 8000 \\
\hline Chemistry & Sealed Lead Acid \\
\hline Weight & $5.70 \mathrm{lbs}$ \\
\hline Length & $5.95 \mathrm{in}$ \\
\hline Width & $2.56 \mathrm{in}$ \\
\hline Height & $3.70 \mathrm{in}$ \\
\hline Price & $\$ 22.95$ \\
\hline
\end{tabular}

The Great Planes ElectriFly Triton DC Comp Peak Charger [34] was chosen to regulate the power from the fuel cell to the battery and load, because of its low cost and adjustable peak detection sensitivity,. The specifications of the battery charger can be seen below in Table 7. With the addition relatively inexpensive Triton battery charger, 
the system was tested in the following three ways: Battery Only, Charging Only, and Charging with Load.

It should be noted the Trition battery charger could provide a maximum of $5 \mathrm{~A}$ and was configured for a $12 \mathrm{~V}$ battery. It also maintained a steady $.3 \mathrm{~A} /$ minute increase or decrease as its power output increased or decreased. This was intended to maintain the safety precautions when charging the lead acid batteries.

Table 7: Battery Charger Specifications

\begin{tabular}{|c|c|}
\hline Input Voltage & $10-15 \mathrm{~V} \mathrm{DC}$ \\
\hline Battery Types, \# of cells & $\begin{array}{l}\text { 1-24 Nickel-Cadmium cells }(1.2-28.0 \mathrm{~V} \mathrm{NiCd}) \\
\text { 1-24 Nickel-Metal Hydride cells }(1.2-28.0 \mathrm{~V} \text { NiMH) } \\
\text { 1-4 Lithium-Ion or Lithium-Polymer cells }(3.6-14.8 \mathrm{~V} \mathrm{Li-} \\
\text { Ion/Li-Po) } \\
\text { 3, } 6,12 \text { Lead-Acid }(6,12,24 \mathrm{~V} \mathrm{~Pb})\end{array}$ \\
\hline Fast Charge Current & 0.1-5.0A linear (2.5A max. for Li-Ion/Li-Po) \\
\hline $\begin{array}{l}\text { Fast Charge } \\
\text { Termination }\end{array}$ & $\begin{array}{l}\text { "zero deltaV" peak detection for NiCd and NiMH }(0-\mathrm{V}) \\
\text { "constant current/constant voltage" for } \mathrm{Pb} \text { and } \mathrm{Li}-\mathrm{Ion} / \mathrm{Li}-\mathrm{Po} \\
\text { (cc/cv) (optional thermal cutoff for all battery types sold } \\
\text { seperately-GPMM3151) cells }\end{array}$ \\
\hline Trickle Charge Current & $0-250 \mathrm{~mA}(\mathrm{n} / \mathrm{a}$ for Li-Ion, Li-Po and $\mathrm{Pb})$ \\
\hline Discharge Current & 0.1-3.0A (2.5A max for Li-Ion/Li-Po) \\
\hline $\begin{array}{l}\text { Discharge Cutoff } \\
\text { Voltage }\end{array}$ & $\begin{array}{l}0.5-1.16 \mathrm{~V} \text { per cell } \mathrm{NiCd} \& \mathrm{NiMH} ; \\
\mathrm{Li}-\mathrm{Ion} / \mathrm{Li}-\mathrm{Po} \text { fixed at } 2.8 \mathrm{~V} \text { per cell; } \\
\mathrm{Pb} \text { fixed at } 1.8 \mathrm{~V} \text { per cell }\end{array}$ \\
\hline Cycle Count & One to ten cycles (n/a for Li-Ion, Li-Po and $\mathrm{Pb}$ ) \\
\hline Battery Memories & 10 battery memories \\
\hline Display Type & 2-line, 32-character LCD \\
\hline Output Connectors & banana jacks \\
\hline Case Size & $6.2 \times 4.0 \times 2.0$ in $(157 \times 102 \times 51 \mathrm{~mm})$ \\
\hline Weight & $16.4 \mathrm{oz}(466 \mathrm{~g})$ \\
\hline Price & $\$ 95.00$ \\
\hline
\end{tabular}




\section{Chapter 4: $\quad$ Test Results}

\subsection{I-V Curves}

Due to the instability of the Horizon fuel cell's IV-curve, it was determined that they should be tested starting at the lowest possible load and gradually increased to the highest, and then run again from the highest to the lowest. The results of these tests can be seen in Figure 25. It is possible that the instability in the Horizon's performance may be due to water management problems. As the performance when decreasing the current is higher than the performance when increasing the current, it could be due to drying out on the cathode side.

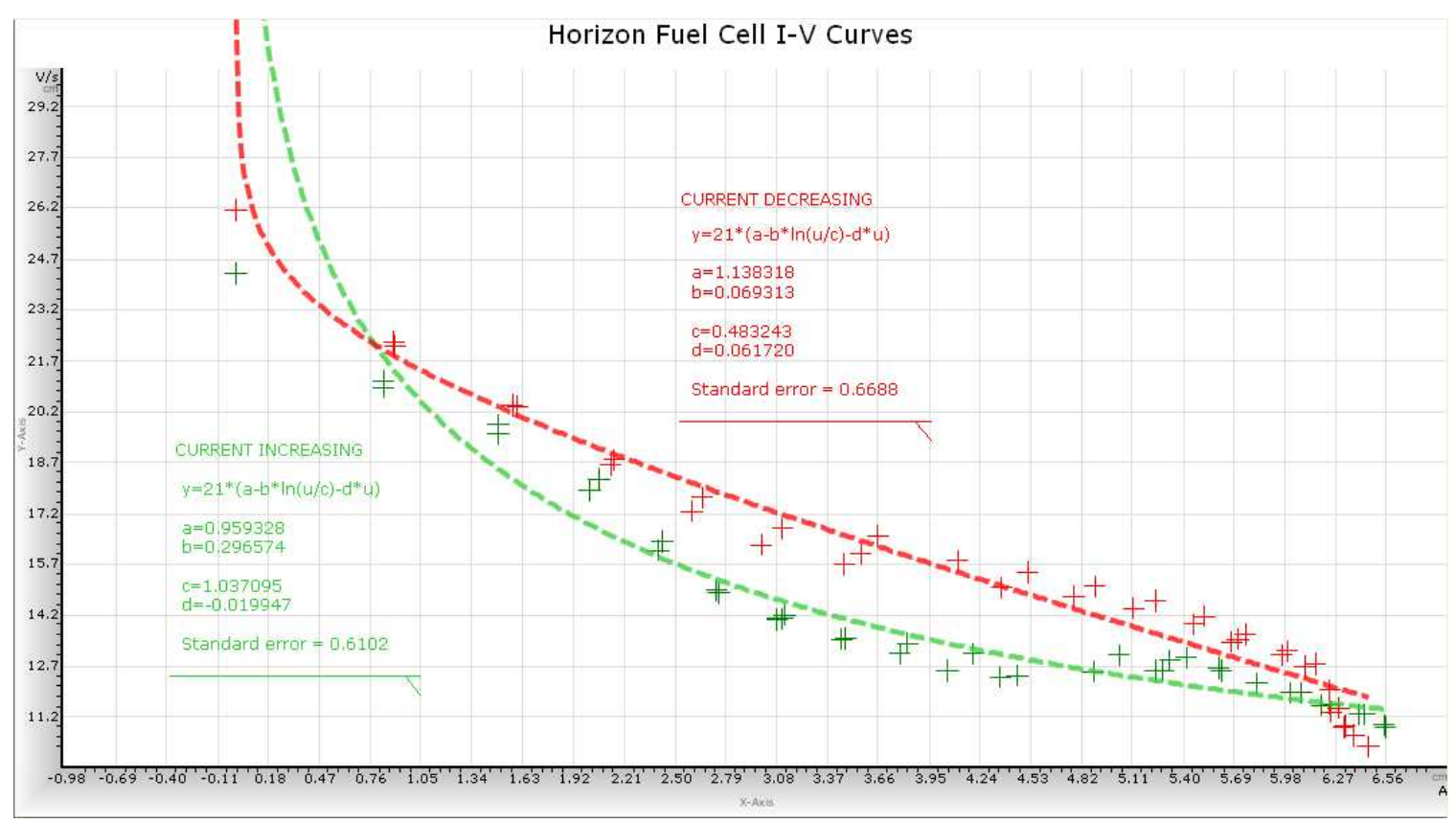

Figure 25: Horizon I-V Curves

The Jadoo fuel cell did not have this issue and the two graphs overlapped. The I-V curve for the Jadoo fuel cell can be seen in Figure 26. It should be noted that the higher voltages of the Horizon fuel cell are due to the fact that it has 8 more cells in the stack than the Jadoo fuel cell. 


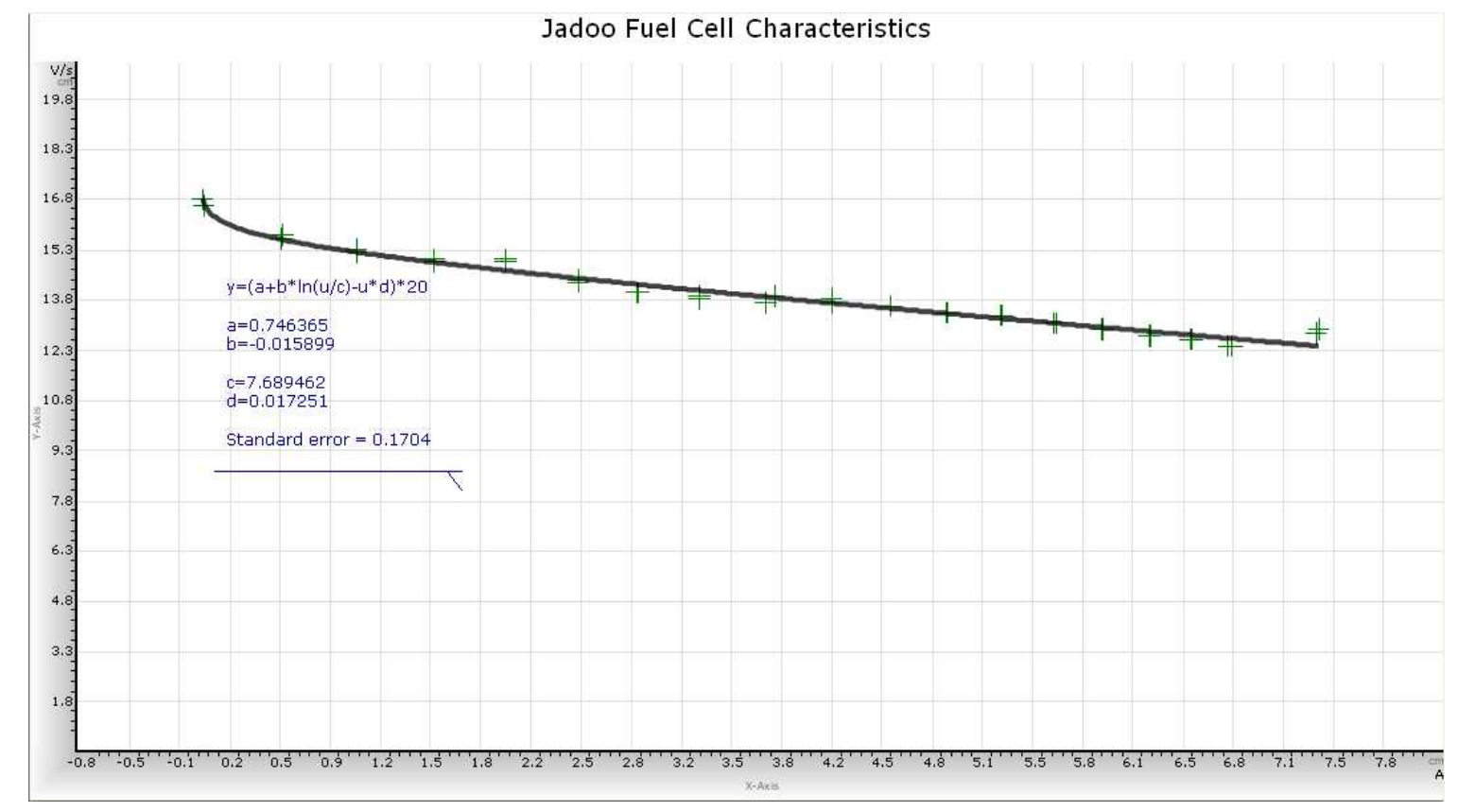

Figure 26: Jadoo I-V Curve

The experimental data was fitted using linear regression techniques to the following equation used to describe the polarization curve, allowing the values for the reversible voltage, transfer coefficient, internal resistance, and reference exchange character to be determined.

$$
V_{\text {stack }}[V]=N_{\text {cell }}\left(E_{r}-(R T) /(\alpha F) \ln \left(i / i_{o}\right)-i R_{i}\right),
$$

Where $\mathrm{E}_{\mathrm{r}}$ is the reversible cell voltage $(\mathrm{V}), \alpha$ is the transfer coefficient, $i_{o}$ is the reference exchange current (A), and $R_{i}$ is the internal resistance (ohms) [1].

\subsection{Purging Tests}

\subsubsection{Jadoo Fuel Cell Test}

Looking at the performance of the Jadoo fuel cell at relatively low and high power outputs (Figure 27 and Figure 28 respectively), there is an obvious difference in the stability of the output. When consistently run at approximately $9 \mathrm{~W}$ (Figure 27), the voltage and current output are both stable, and purging once after 7 minutes appeared to have little to no effect. Typically, at very low power outputs, the fuel cell would purge more rapidly at start-up, but would settle to purge every 20 minutes. 


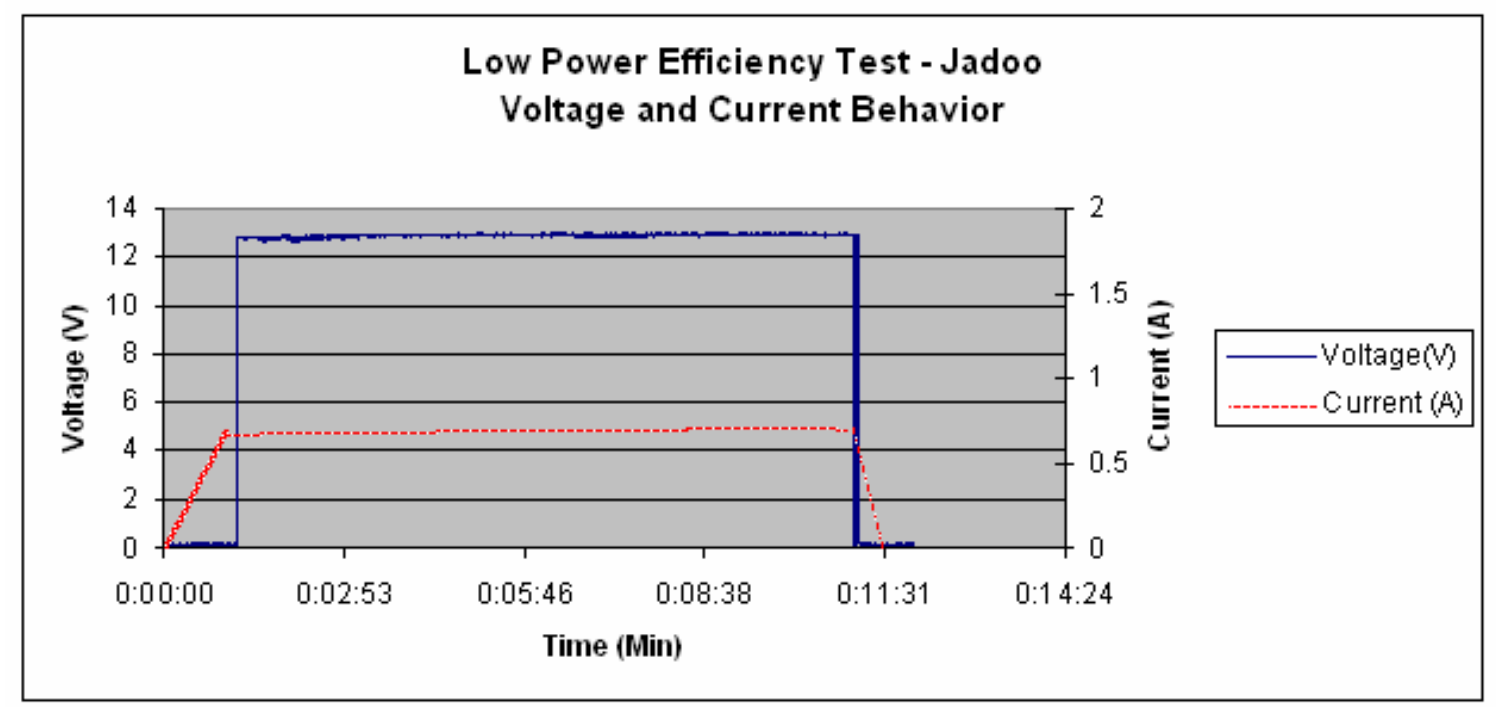

Figure 27: Jadoo Low Power Performance

However, when run at approximately 100W (Figure 28), purging had a more significant effect, occurring every 6 to 8 minutes and raising the constantly dropping voltage by $0.3 \mathrm{~V}$ at each purge.

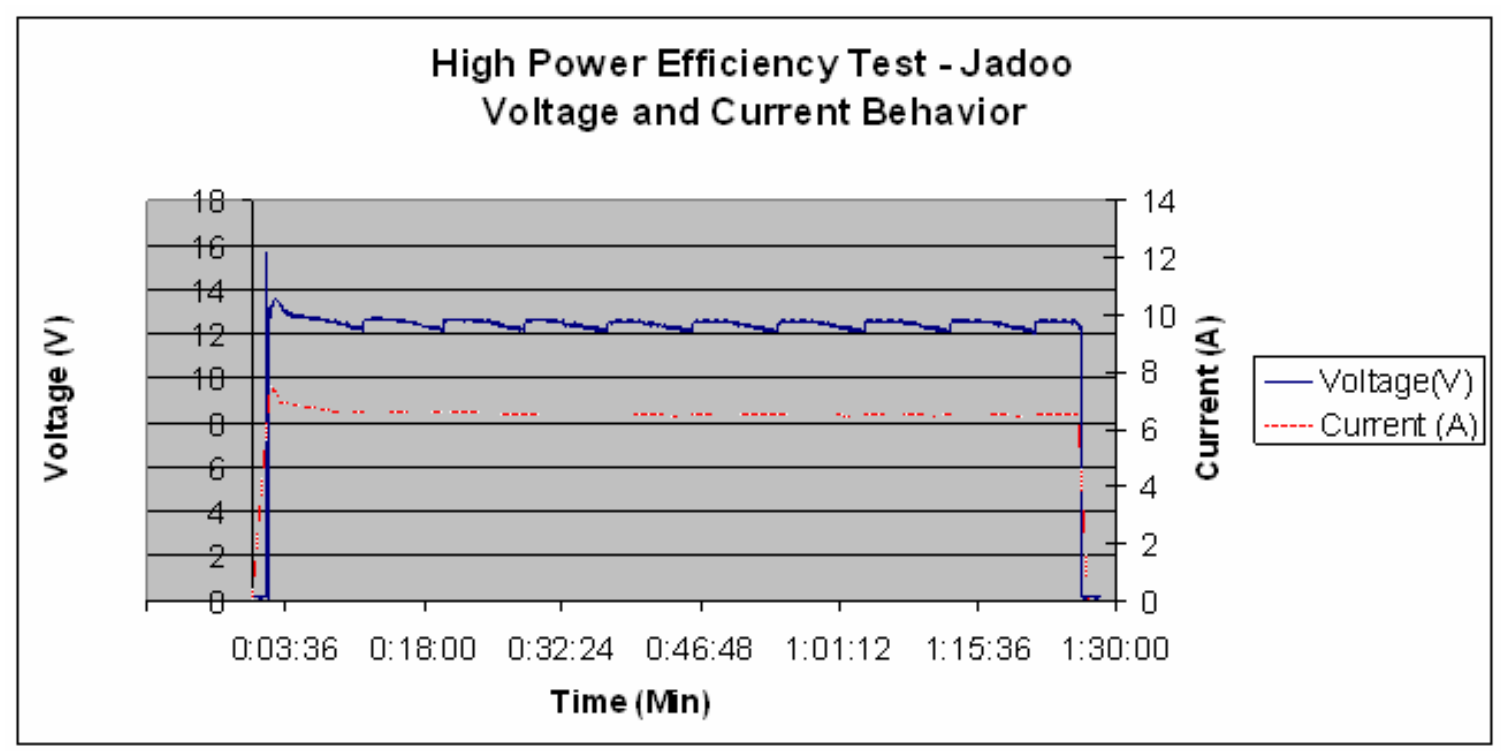

Figure 28: Jadoo High Power Performance

To examine the effect that purging the dead ended stack had on the Jadoo fuel cell, it first was run under normal conditions. In this test the fuel cell operated at low power $(<30 \mathrm{~W})$ for a duration, before swiftly raised to a higher power $(>90 \mathrm{~W})$. 
Typically, when the fuel cell provided less than $90 \mathrm{~W}$ it purged every 20 minutes. Above $90 \mathrm{~W}$, it purged every 7-8 minutes, as well as needing to purge whenever the load was drastically altered. Each purge consisted of two successive 0.16 second pulses, and was timed to restore the fuel cell voltage and current to maximum performance. The purges were scheduled to take place every 20 minutes or every time there was a rapid drop in the voltage.

The voltage was measured at every five cells of the stack. The cells were connected in series therefore the voltage of each level is added to the voltages of the levels beneath it. The hydro and purge signals measure the hydrogen and purging solenoids, respectively. The purge solenoid controls the hydrogen purging used in the dead-ended operation of the cell. Graphs of these measurements can be observed in Figure 29 and Figure 30. The hydrogen cylinder returns a steady signal for as long as the unit is on and receiving hydrogen.

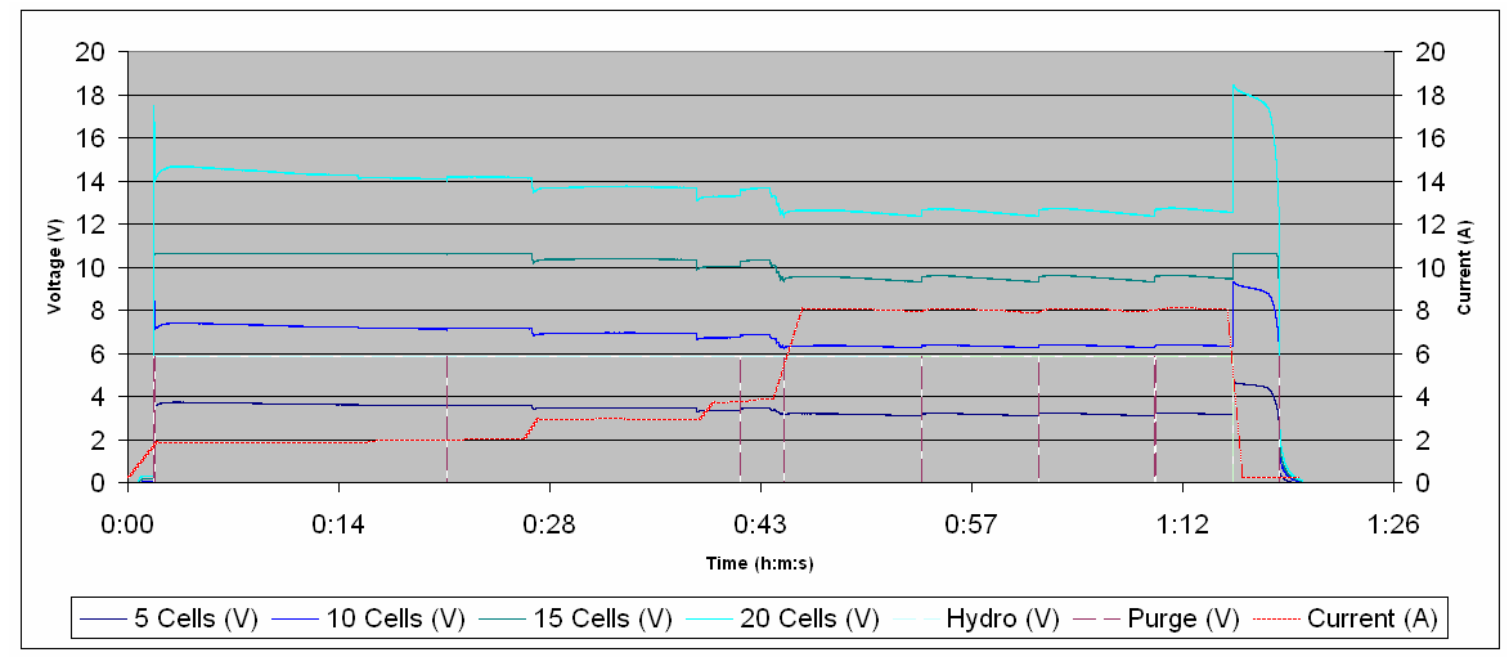

Figure 29: Overview of Stack and Solenoid Voltages with Stack Current 

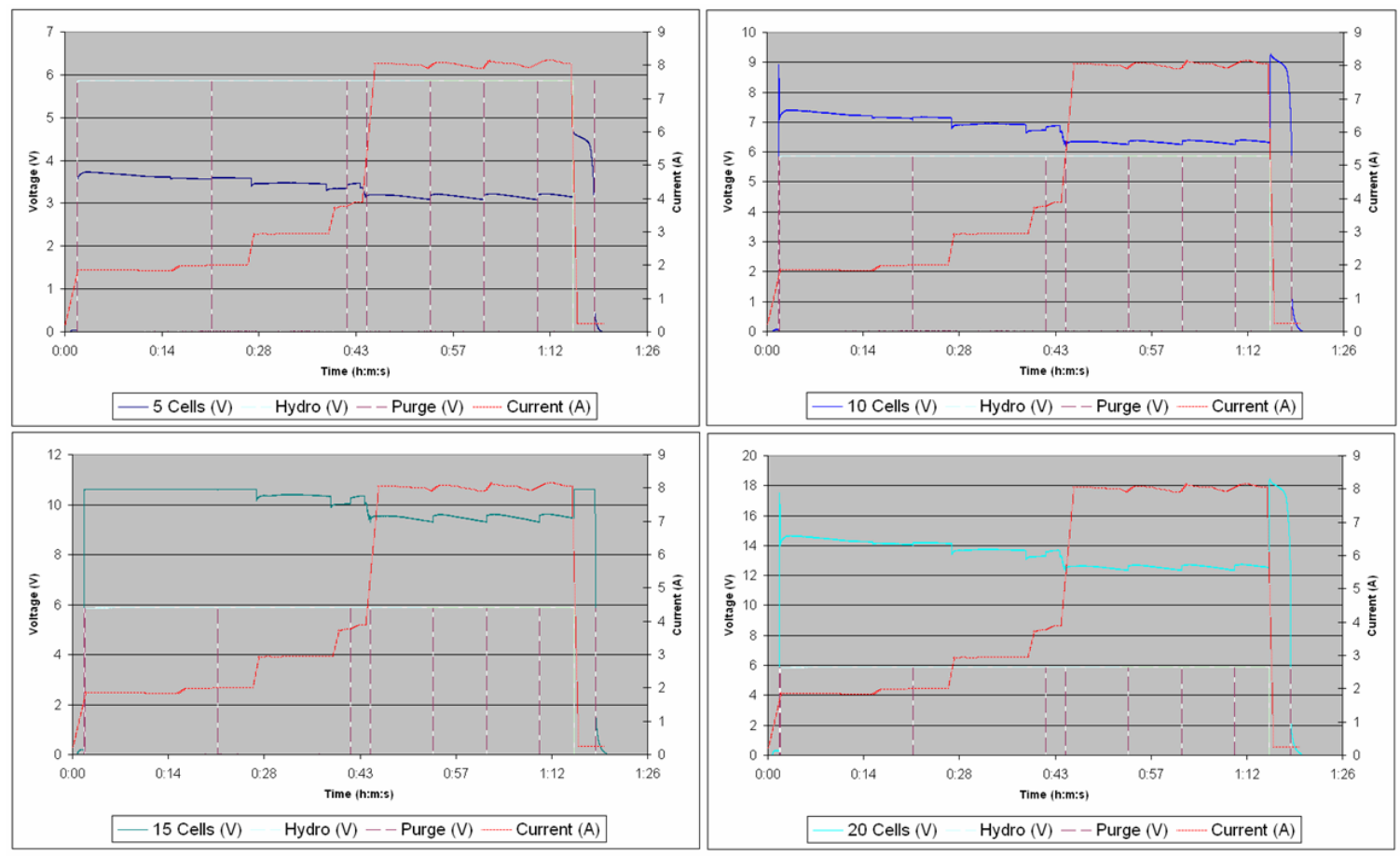

Figure 30: Individual Stack Levels with Stack Current and Solenoid Signals

Figure 31 presents the voltage signal and the fan signal over the time period.

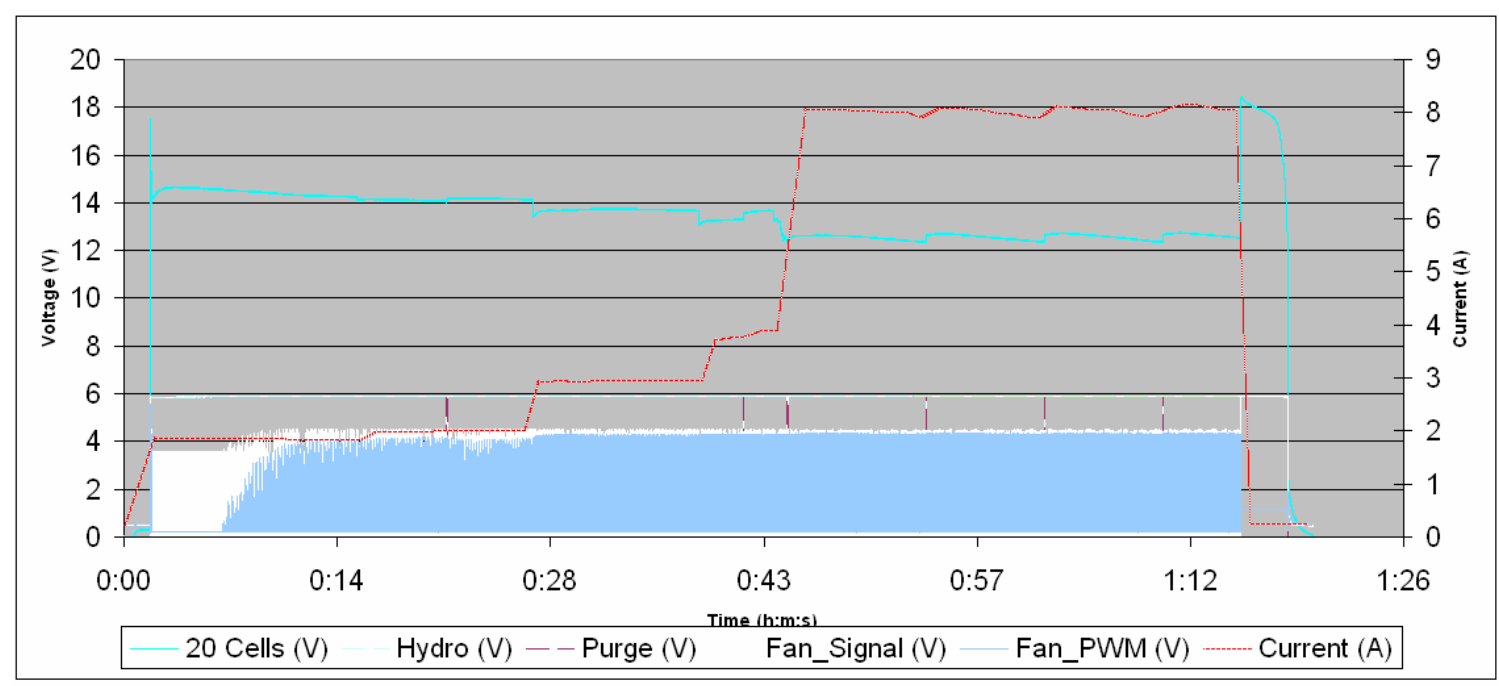

Figure 31: Jadoo PWM Fan Signals

To examine how the fuel cell would perform without purging, the purging solenoid signal was unplugged from the fuel cell control ensuring that the solenoid would remain closed. Occasionally the solenoid signal was restored to observe the adjustments 
made when the purging was added back into the operation. The times when the solenoid was not plugged into the circuit can be observed by its abbreviated signal. Figure 32 presents an overview of all of the stack voltages, overall stack current, and solenoid signals for the entire duration of the test.

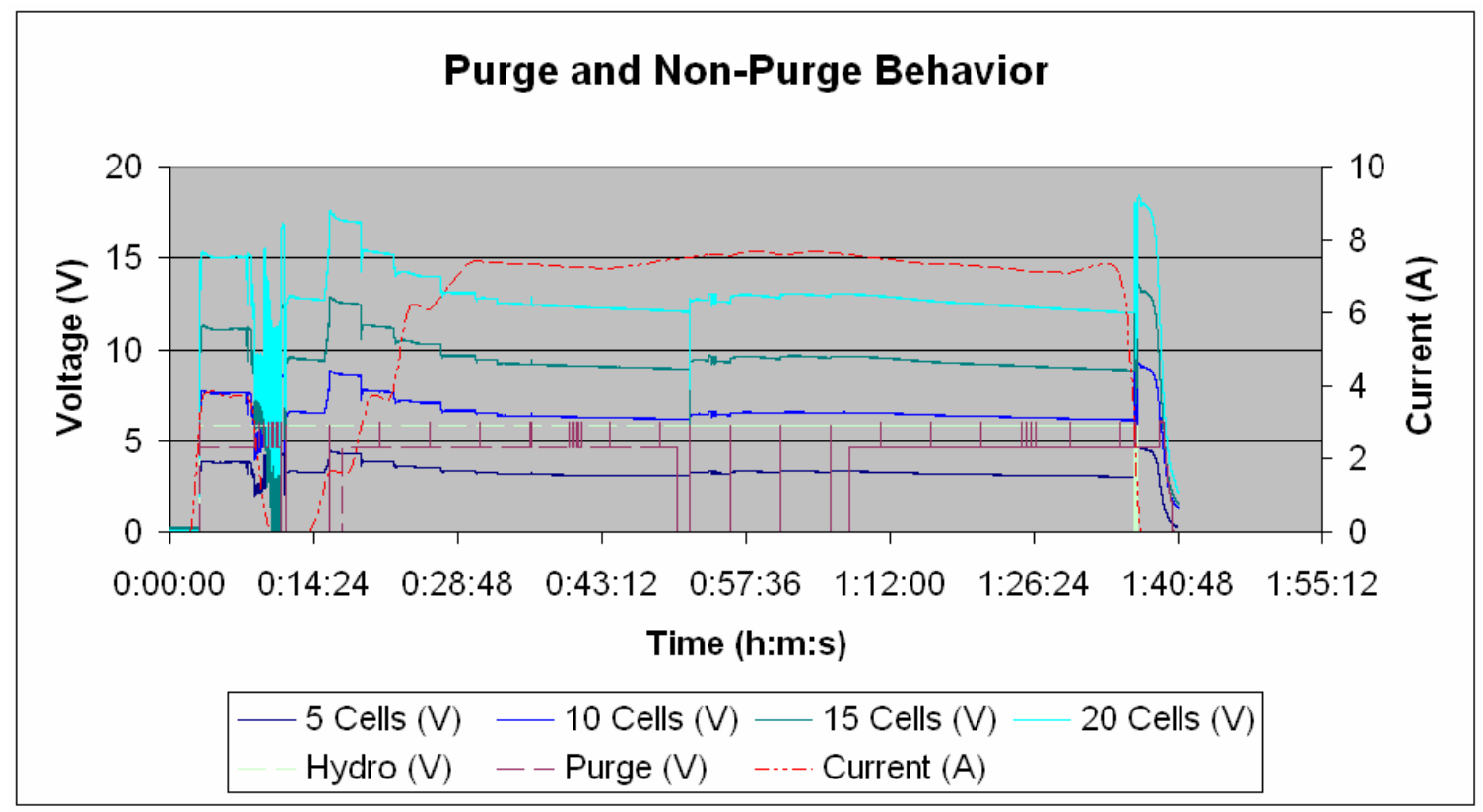

Figure 32: Overview of all Jadoo signals, stack voltages, and current with and without purging

When the unit was immediately introduced a $95 \mathrm{~W}$ load, the voltage readings of the stack went haywire. There were numerous attempts by the fuel cell to periodically purge the hydrogen, but as it did not the voltage continued to fluctuate until the unit's internal failsafe shut down the cell after which the purging solenoid signal was reenabled. The fluctuation was most likely due to water imbalance with the cells disrupting the gas flows. When the purging solenoid was plugged back in, the unit re-stabilized. This can be more closely observed in Figure 33, Figure 34 and Figure 35. 


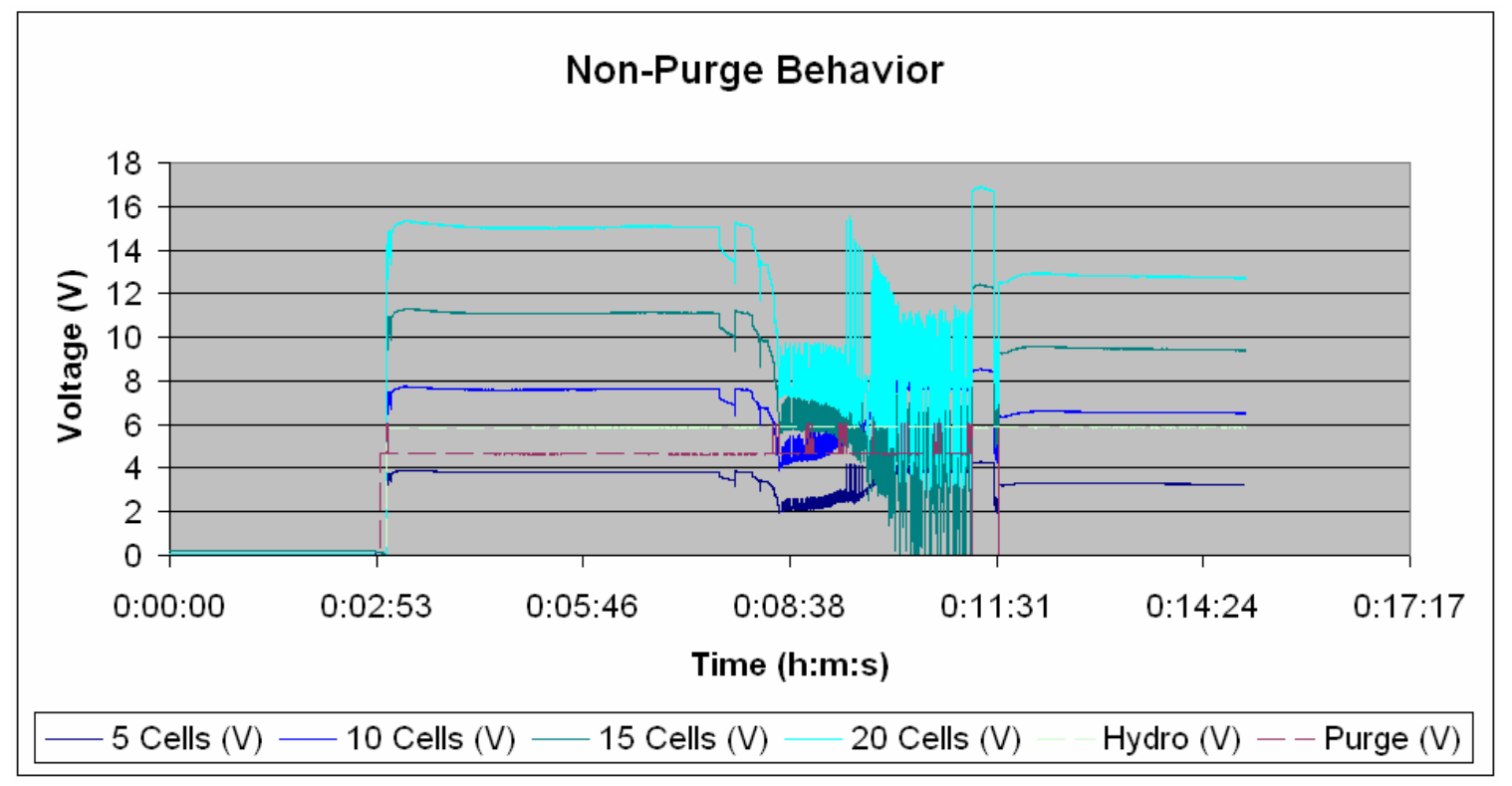

Figure 33: Overview of all Jadoo Signals after a Sudden Heavy Load Without Purging
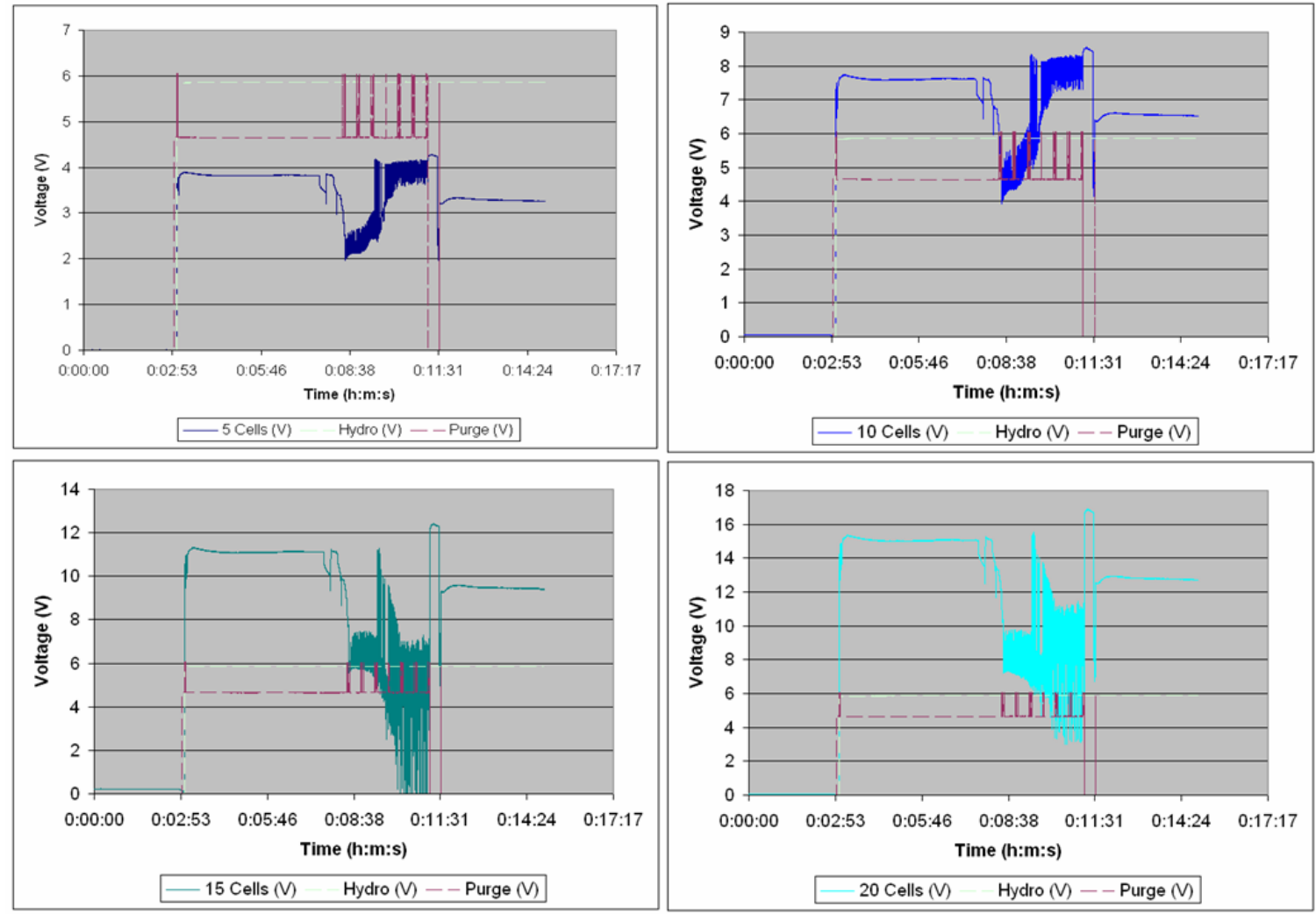

Figure 34: Individual Jadoo Stack Voltage after a Sudden Heavy Load was Introduced 


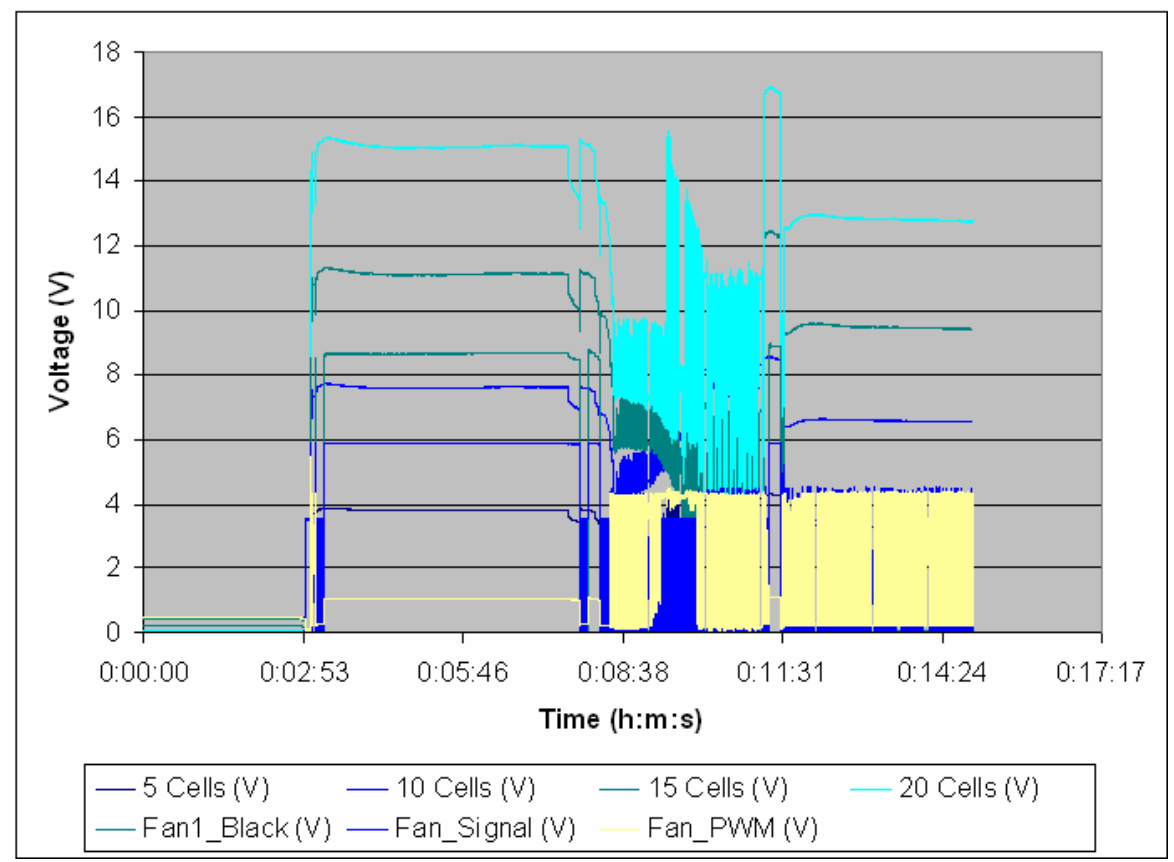

Figure 35: Jadoo fan behavior after heavy load addition

In contrast, when the load was slowly increased, the voltages remained steady. However, without the purging to occasionally perk the voltage up, it steadily decreased at continuous rate as can be seen in Figure 36. The fan behavior in this period is shown in Figure 37.

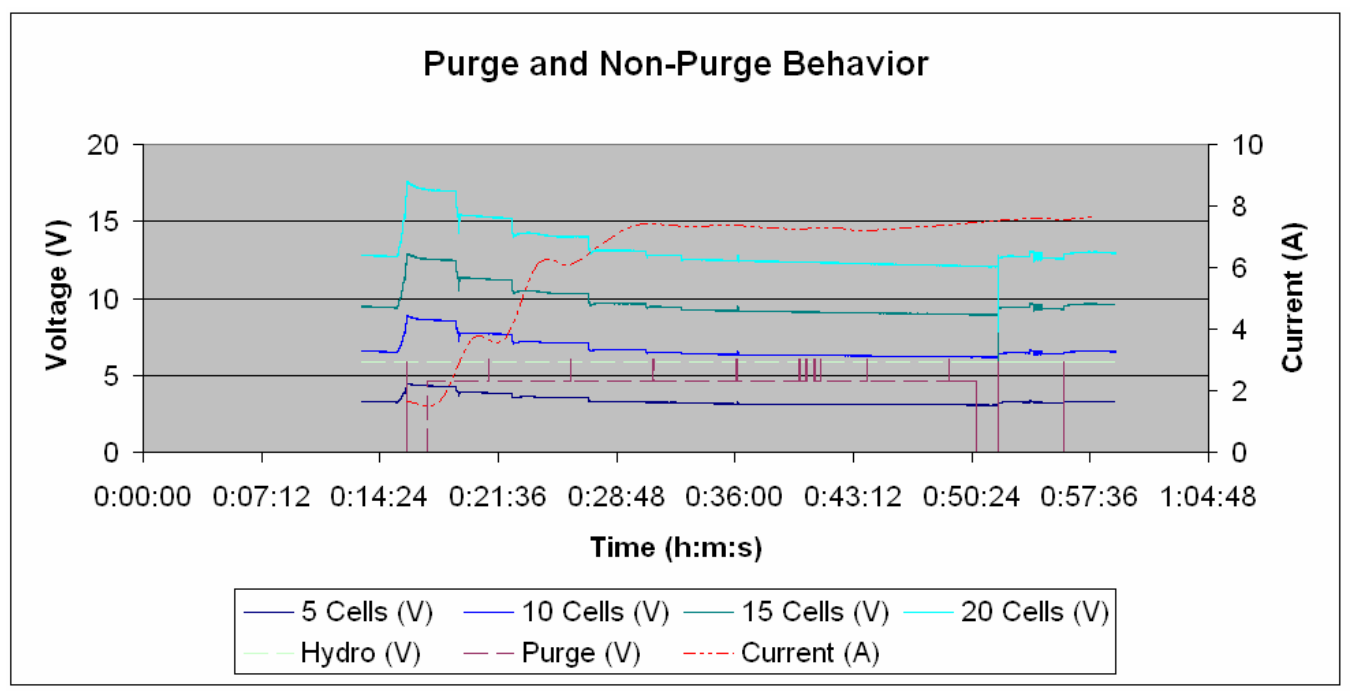

Figure 36: Jadoo signals during slow increase of the load without purging 


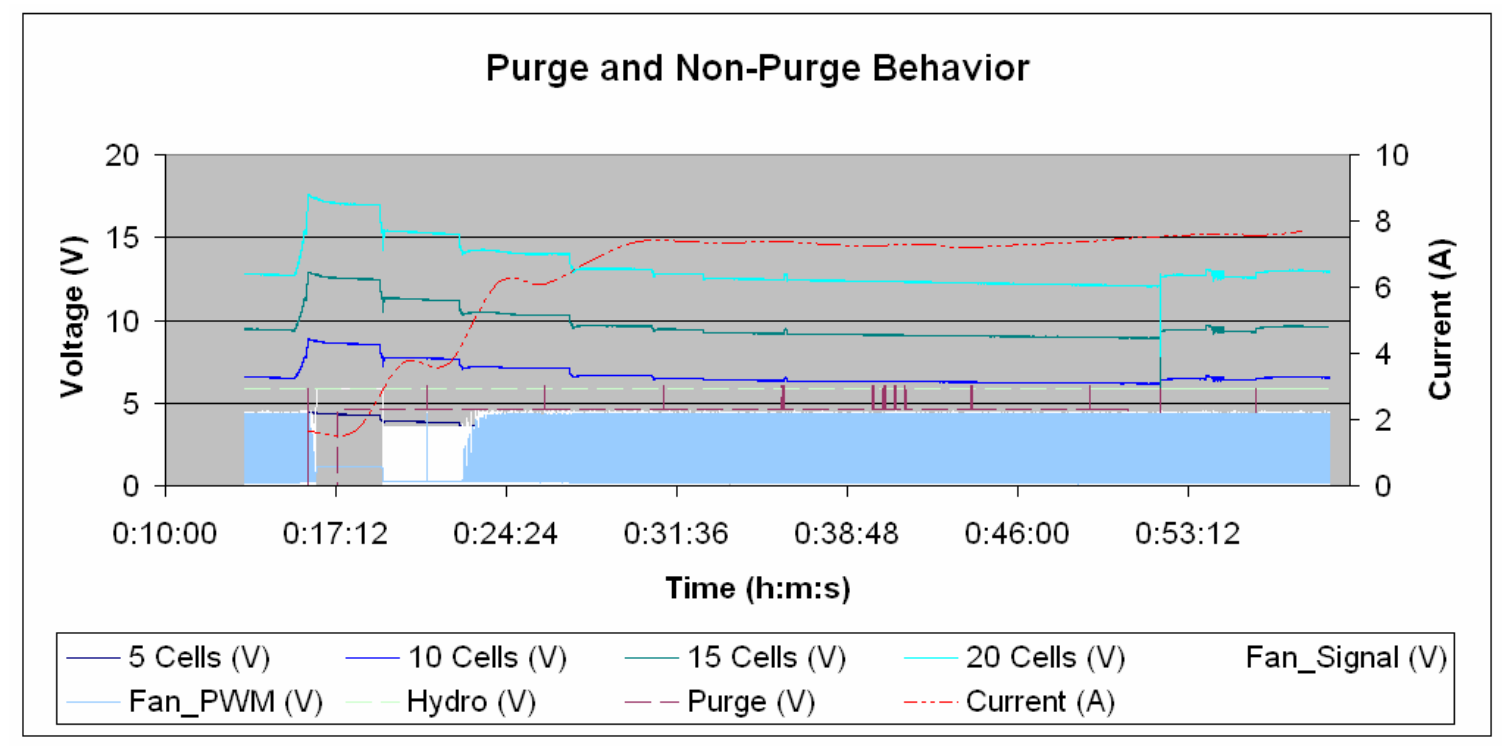

Figure 37: Fan readings during slow load increase

In Figure 38 and Figure 39, the difference between running with and without purging can be easily compared. When the input hydrogen solenoid was plugged in, as can be seen in the first part of the graph (when the hydrogen solenoid signal reached down to zero), the fuel cell was able to maintain a steady voltage. However, when it was removed in the latter part of the graph, the voltage can be seen to steadily decrease. The fan controls appear to be completely dependent on the fuel cell's temperature.

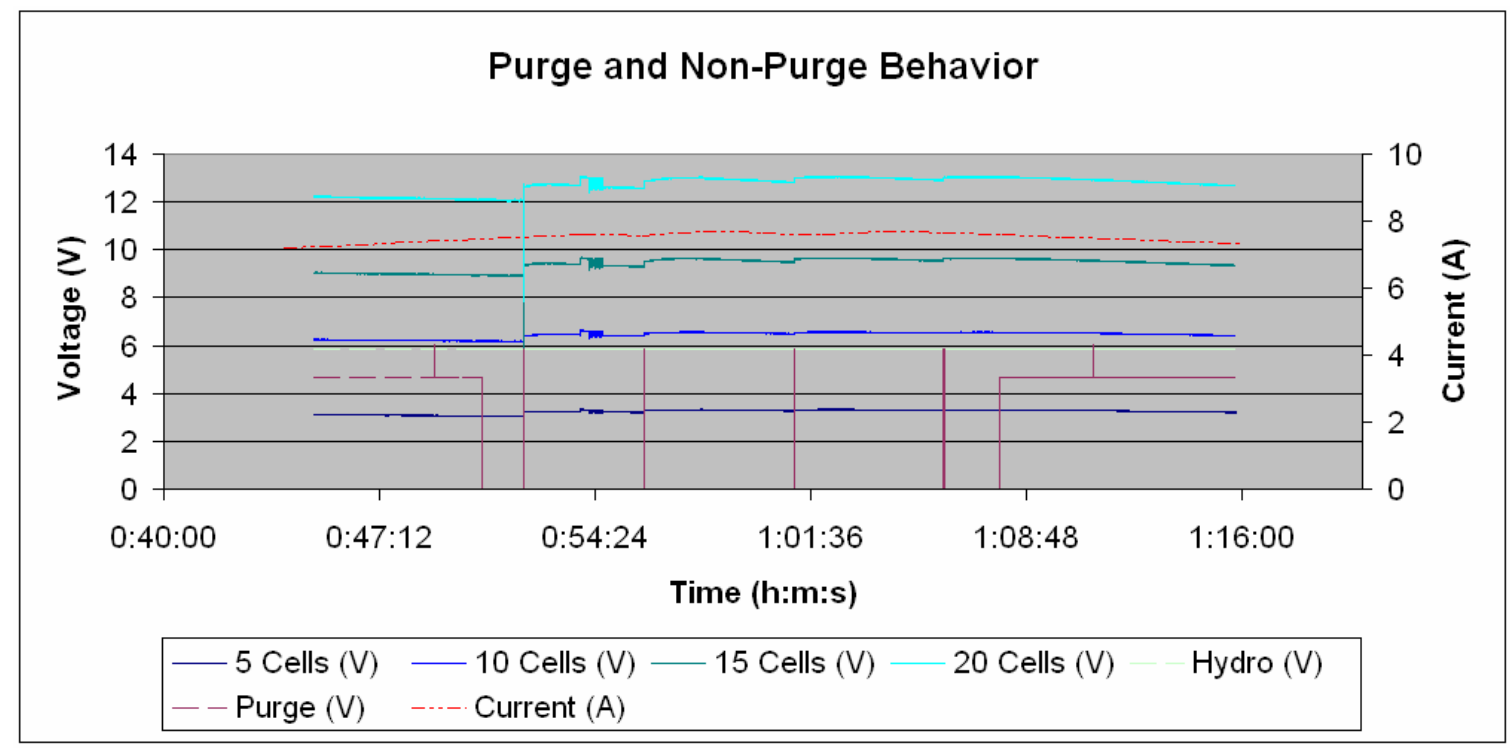

Figure 38: Overview of all signal behavior with and without purging system 


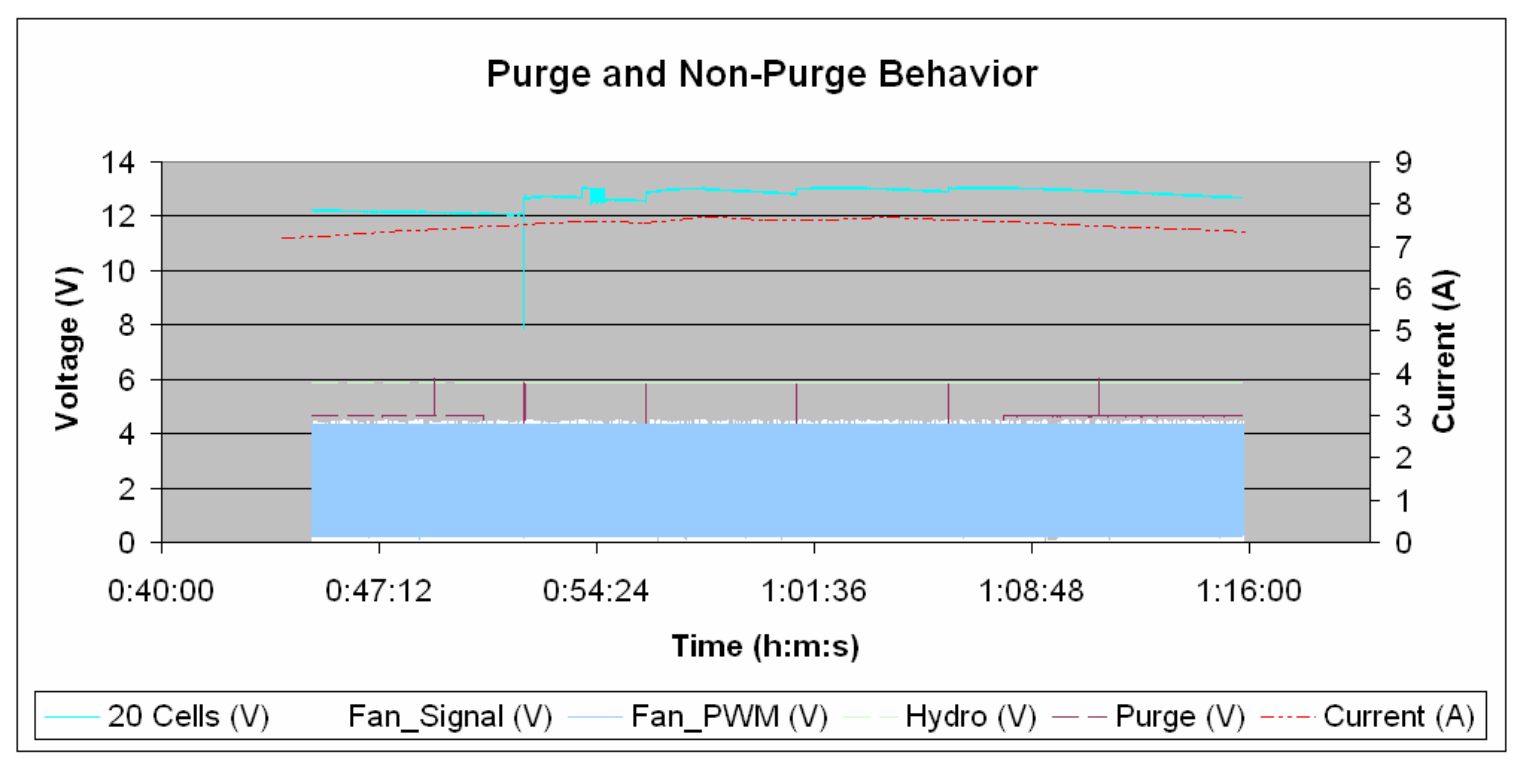

Figure 39: Fan behavior with and without purging

\subsubsection{Horizon Fuel Cell Test}

The purging tests were continued with the Horizon fuel cell that allowed the user the control the purging times, fan speed, and inlet pressure. When the Horizon ran at a lower power output, (example shown in Figure 40), it required little to no purging to maintain a steady voltage.

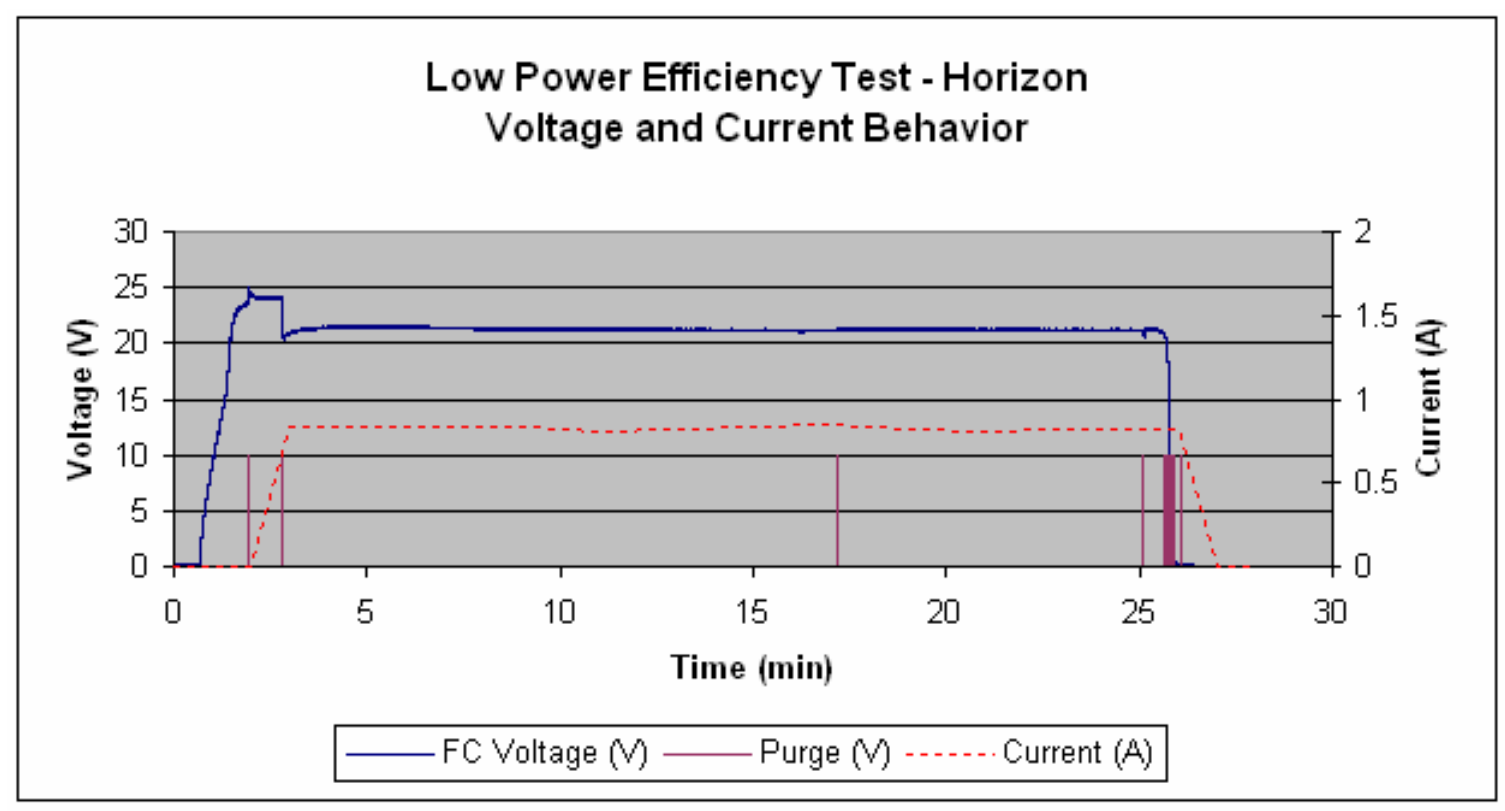

Figure 40: Voltage Behavior Graph of the Horizon Low Power Test 
Through experimentation, it was determined that the most effective setting for the lower loads with power outputs below $40 \mathrm{~W}$ was to run the controller so that it would purge whenever the voltage dropped by $0.3 \mathrm{~V}$ and at higher power outputs by $0.4 \mathrm{~V}$. At higher power outputs, as in Figure 41, the voltage drops immediately upon the connection of the load and then steadily increases. During the middle of this run, the new controller was used to manually purge the system, which pushed the voltage up immediately. At this point, the voltage continued in a series of rapid purges, which occurred whenever the voltage dropped $0.4 \mathrm{~V}$, which kept the voltage moderately stable at its highest point for this load.

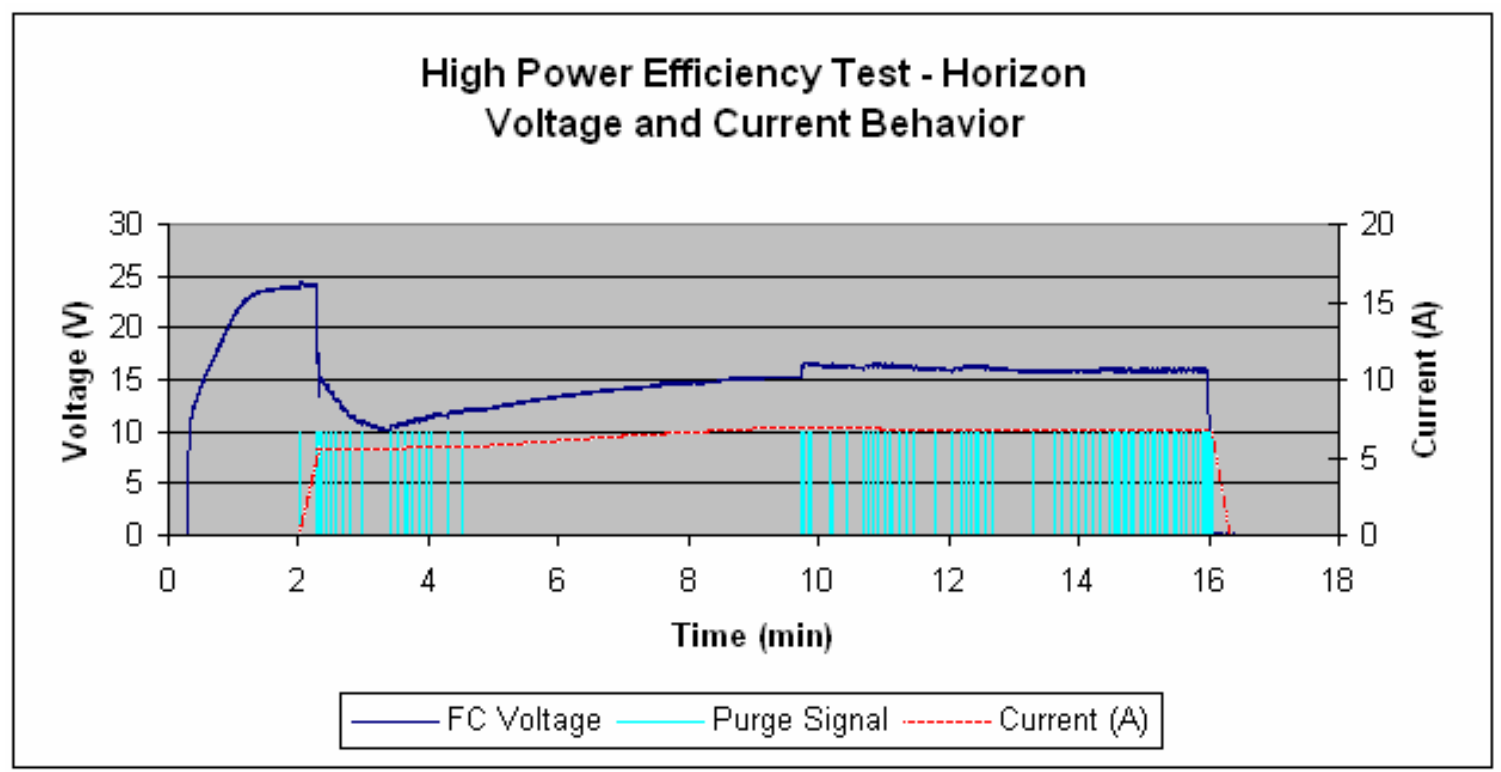

Figure 41: Voltage Behavior Graph of the Horizon High Power Test

Low voltages from $0-12 \mathrm{~W}$, are steady with a slight decrease over time. The oddest behavior displayed by the fuel cell, is that at higher wattages, the voltage will periodically go to $0 \mathrm{~V}$ before immediately returning. A $20 \mathrm{~W}$, the drops occur approximately every $2 \mathrm{~min}$, with the time periods between each drop getting slightly longer each time. At $40 \mathrm{~W}$, the drops occur approximately every 20 seconds, and all higher loads every 10 seconds. Purges generally occur a few seconds after the most recent purging signal is sent. Pressure and temperature readings for these tests can be found in Appendix A. 


\subsection{Measuring the Fuel Flow Rate}

The power output of the Jadoo fuel cell as the flow rate was increased is shown in Figure 42,

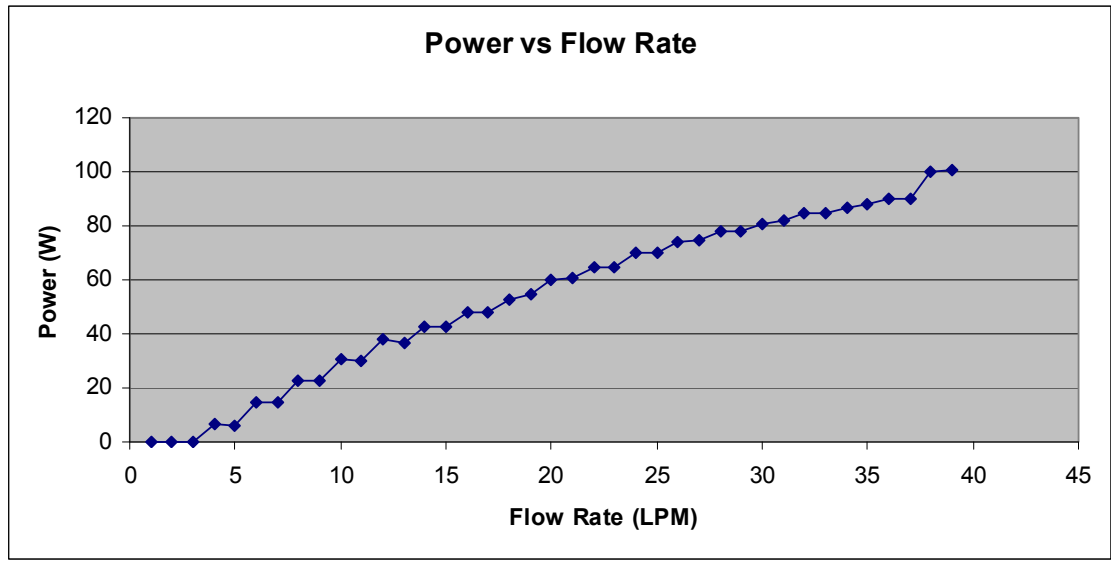

Figure 42: Power versus Flow Rate

the voltage output of the Jadoo fuel cell as the flow rate was increased is shown in

Figure 43,

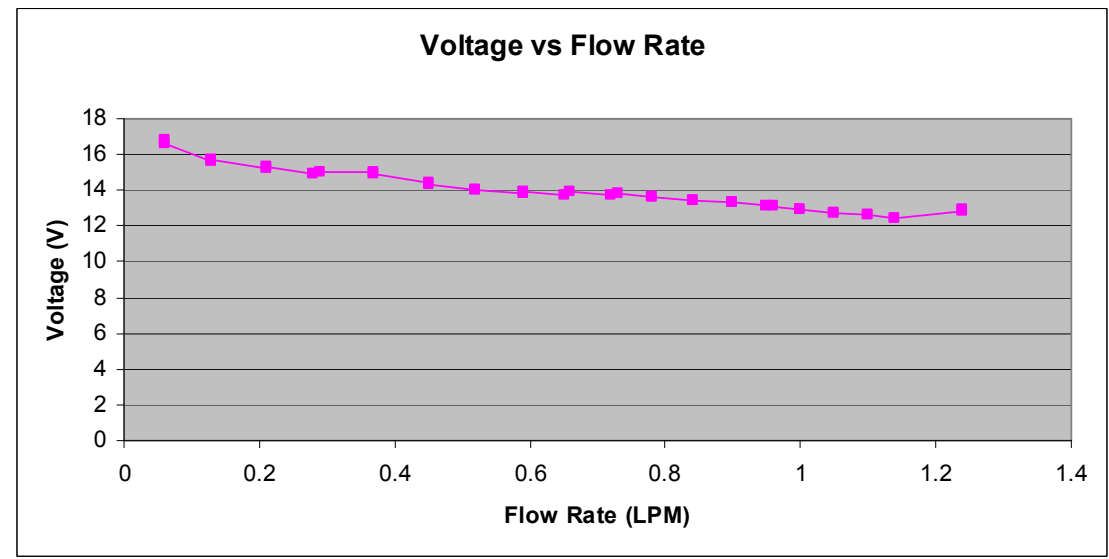

Figure 43: Voltage versus Flow Rate

and the current output of the Jadoo fuel cell as the flow rate was increased is shown in Figure 44. 


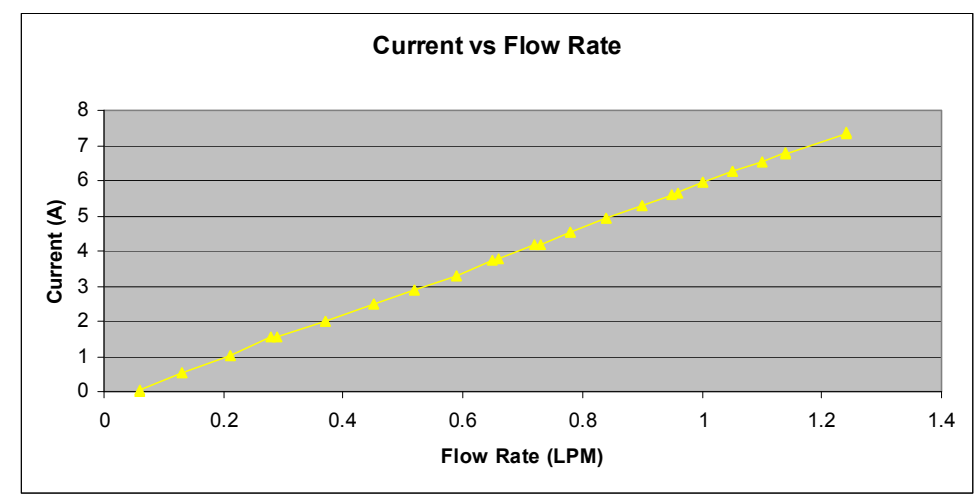

Figure 44: Current versus Flow Rate

The results are detailed in Appendix B. Through experimentation, it was learned that the control system on the fuel cell determines the flow rate as a function of current, using the following approximate equation:

$$
L P M=0.15 * \text { Current }+0.06
$$

where the 0.06 is the flow rate required to power the fuel cell control system itself, including the LCD screen. The current in the fuel cell was measured using a $3 \mathrm{~W}, 5 \mathrm{~m} \Omega$ low value current sensing resistor.

Looking at the measured actual flow rate and the calculated consumption flow rate of the Jadoo fuel cell in Figure 45, the actual flow rate is observed to closely follow the theoretical values indicating that for the most part that the fuel efficiency does have a stable relationship with the current.

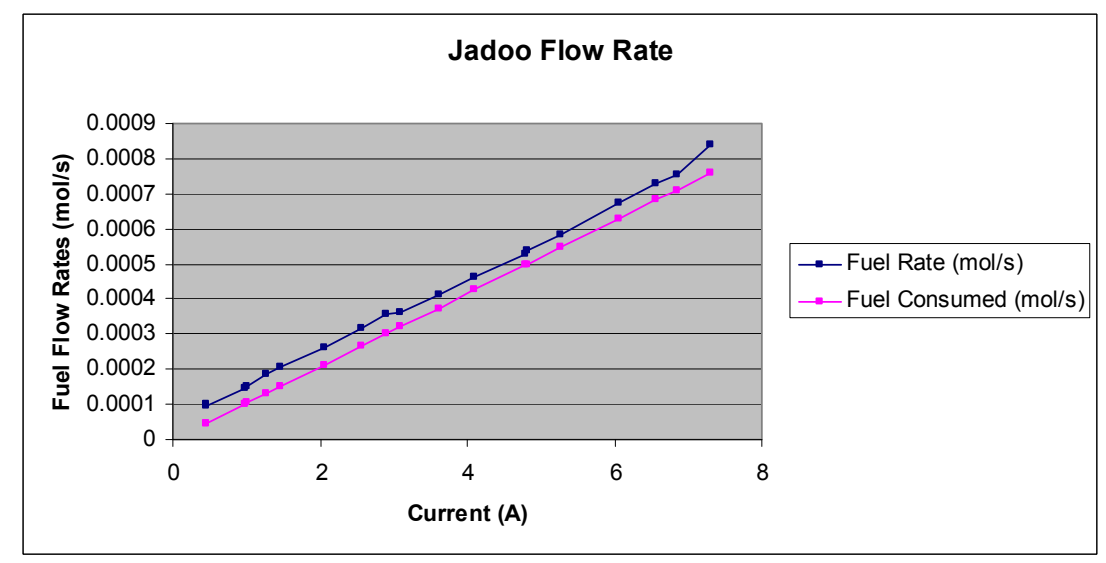

Figure 45: Comparing the Jadoo Actual Flow and Consumption Rates 
Monitoring the flow rate of the Horizon on the other hand is based solely on the monitoring the amount of fuel used over time. When measuring the flow rates of the Horizon, it performance was more erratic probably due to difficulty in regulating the input.

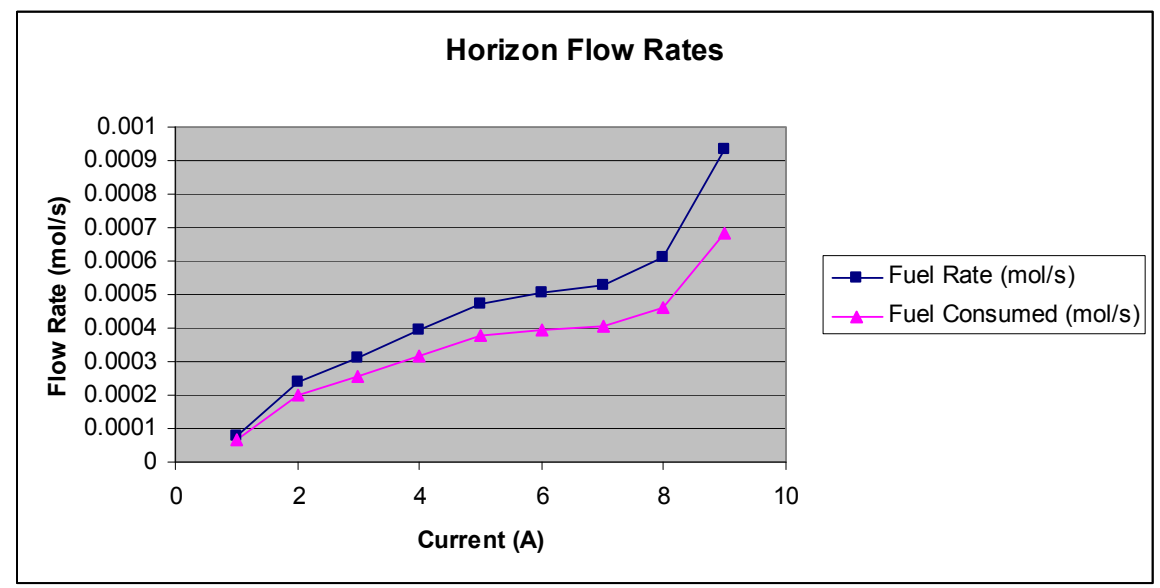

Figure 46: Comparing the Horizon Actual Flow and Consumption Rates

\subsection{Fuel Consumption Tests}

The results of the fuel efficiency tests of both stacks total performance shows that the Jadoo stack has a much wider operating range than the Horizon. Comparisons of the two fuel cells' energy densities is shown in Figure 47. This may be due to the Horizon's small construction flaws in the stack, difficulty in regulating the inlet pressure, or in the rapid purging required for all but the smallest of power outputs. The minor drop in the energy per gram of hydrogen of the Jadoo system at its lowest load may be due to the fan being off during at this time and there being less oxygen than optimal entering of the stack. 


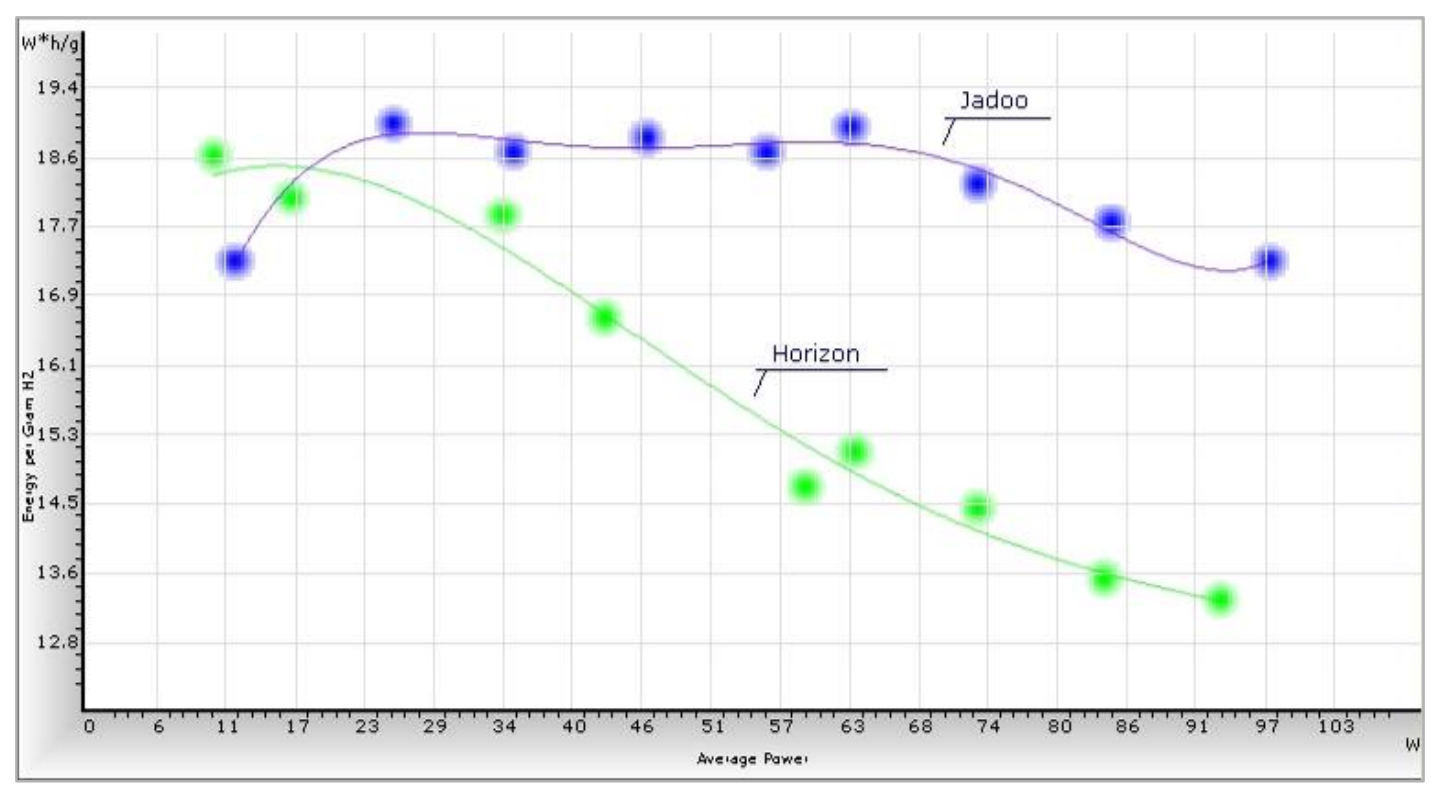

Figure 47: Comparing the Horizon and Jadoo Energy Densities

In Figure 48, the practical efficiency for the Jadoo was observed to have a lower efficiency when run at very low power outputs, most likely due to this period having low temperatures and the fan not running. Average and higher loads had a consistent efficiency that was comparable to the Horizon's at its highest. The overall practical efficiency of the cell was $42 \%$, and it reached a peak of $48 \%$ at $60 \mathrm{~W}$.

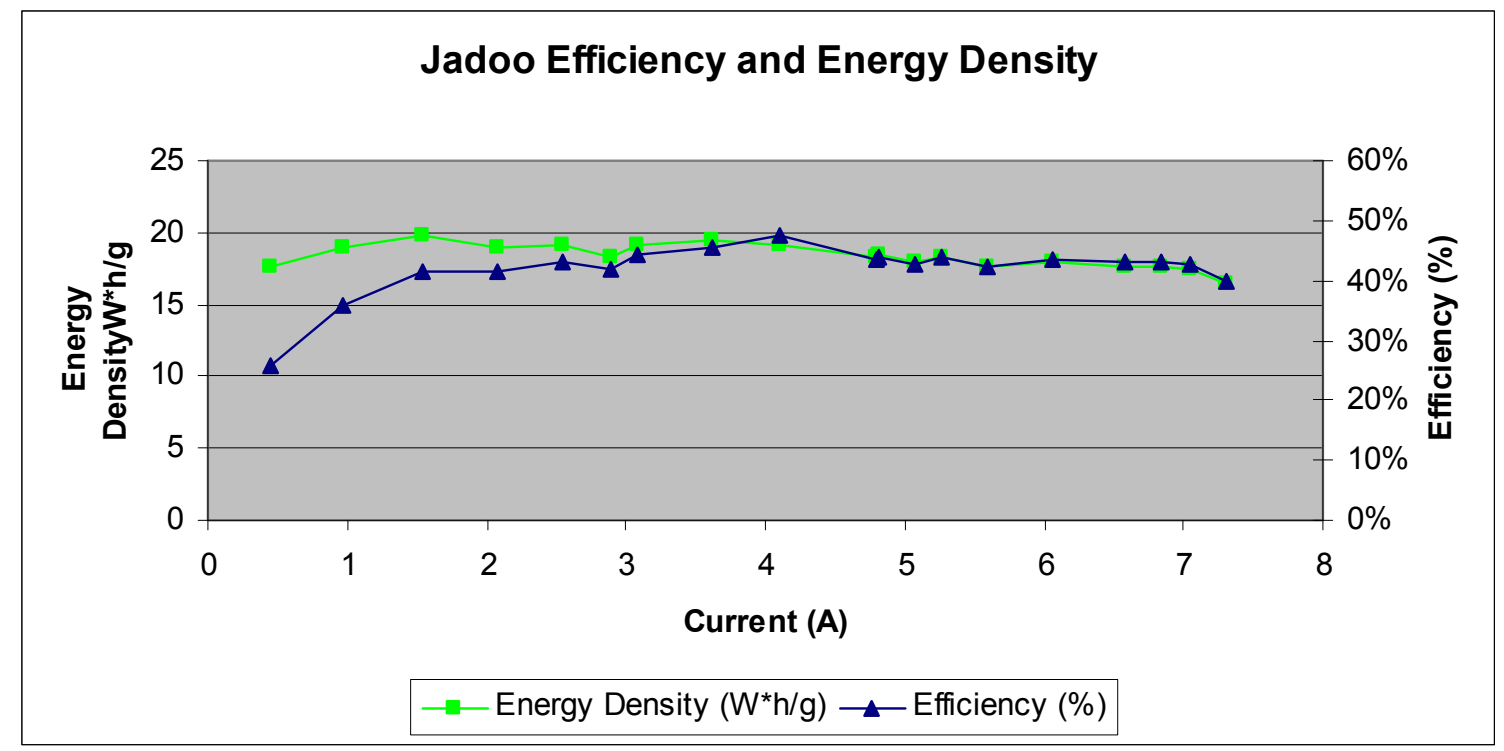

Figure 48: Jadoo Fuel Efficiency and Energy Density 
In testing the Horizon, it was possible to observe how altering the purging cycle could effect the efficiency of the system. The configuration in testing was as described in Section 4.2.2, wherein the purging system was set to purge for $0.7 \mathrm{sec}$ when the voltage dropped $0.4 \mathrm{~V}$ for high powered tests and $0.3 \mathrm{~V}$ for low powered tests. The results for these can be seen in Figure 49. The Horizon had an overall average efficiency at 34\%, and a higher efficiency when run at lower power outputs, with the measured efficiency peaking at $48 \%$ at $10 \mathrm{~W}$.

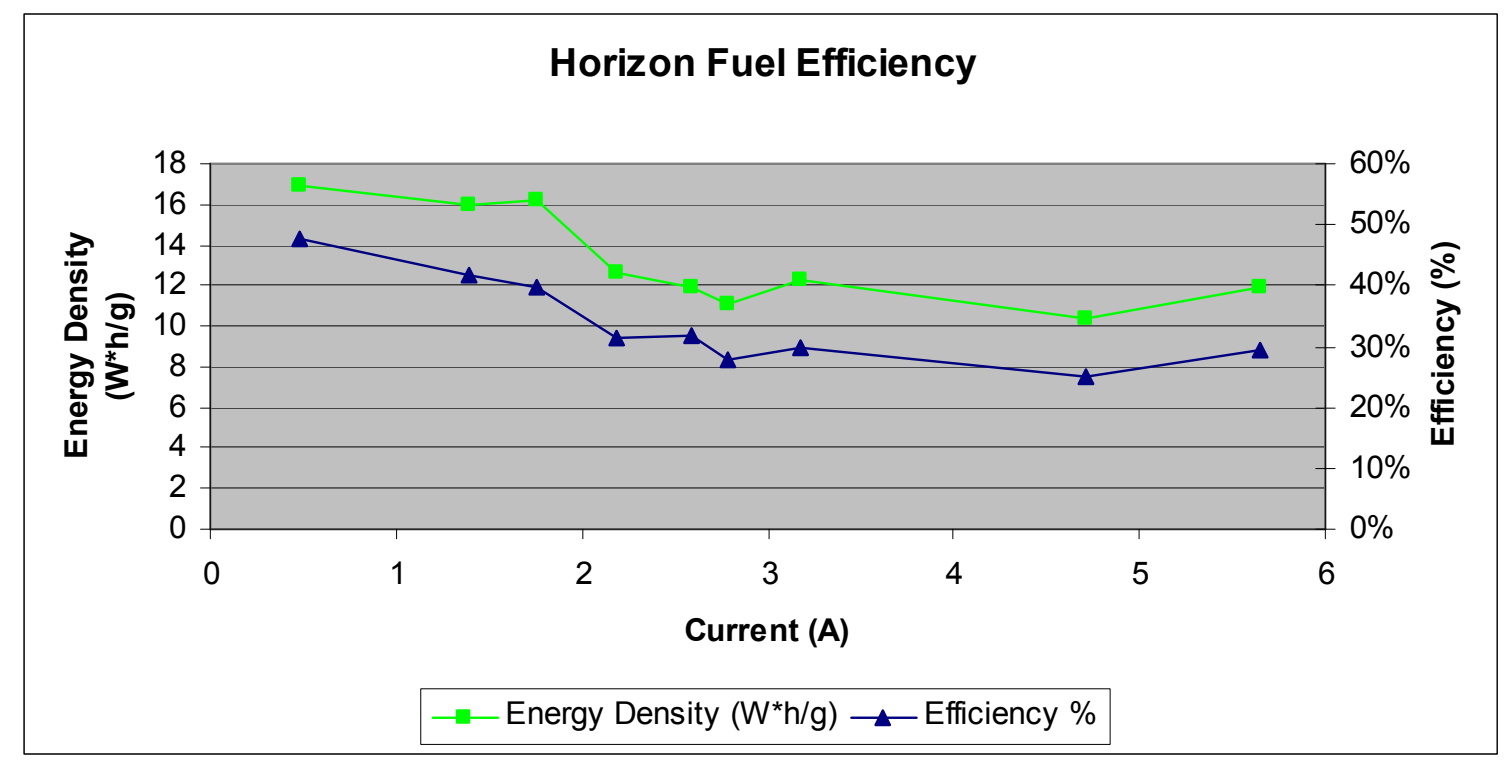

Figure 49: Horizon Fuel Efficiency and Energy Density

\subsection{Simple Fuel Cell and Battery Hybrid Performance}

The results of the first test show how the battery alone would work with the load. As shown, the battery's performance immediately starts to degrade and when started with a maximum load of $230 \mathrm{~W}$, can only maintain the performance for approximately 12 minutes before suffering a severe drop in performance. 


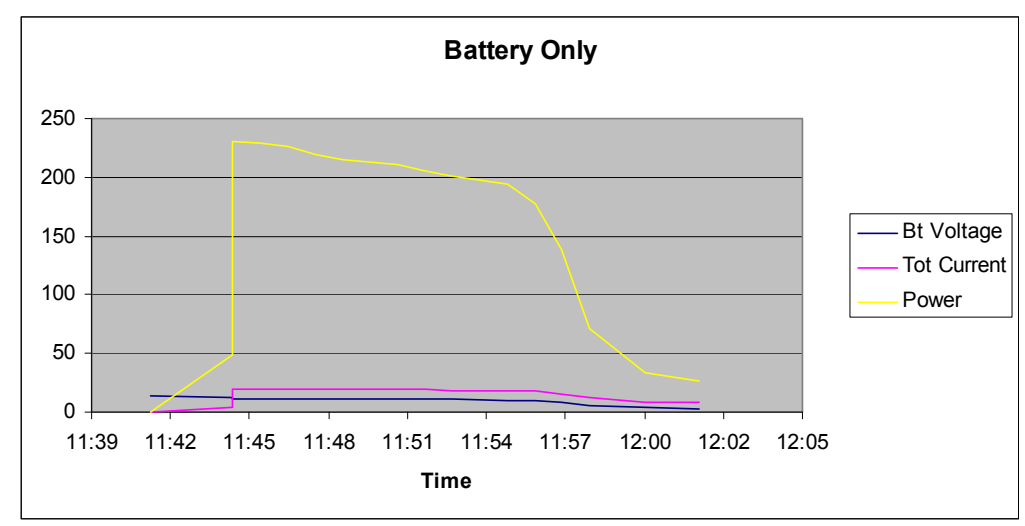

Figure 50: Battery only performance

When testing without a load, it simulates how the system could charge the battery while the vehicle is stopped, and can be seen in Figure 51. The detailed readings of this test can be seen in Appendix C.

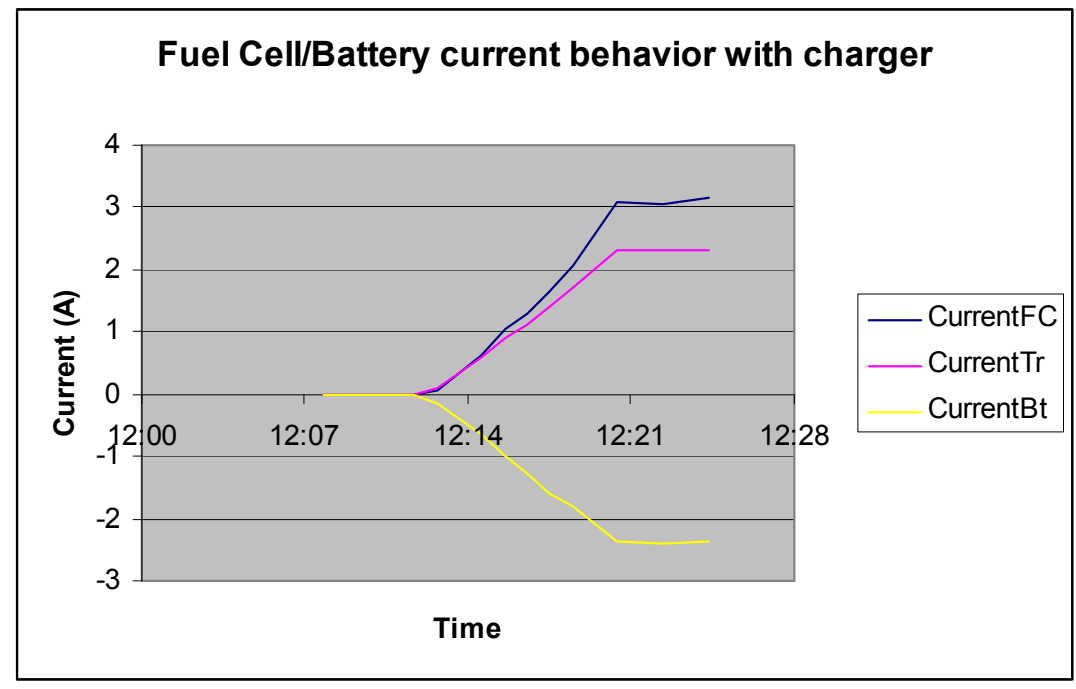

Figure 51: Fuel Cell/Battery current behavior with charger

If the battery is already charged, the maximum current provided by the charger will stop at $0.1 \mathrm{~A}$, but if the battery is low it will proceed to increase the current charging the battery until the voltage of the battery reads $14.3 \mathrm{~V}$ or the current maxes out at $5 \mathrm{~A}$. It will maintain the maximum current reached until the battery's voltage increases to the point that the extra current going to the battery is no longer needed, at which point it will begin to decrease. It should be noted that one limitation of the Triton battery charger is that after it has reached a max current, it will need to be restarted before being able to 
increase that max current level, even if the battery has been run down. The third test demonstrates how the charger powered by the fuel cell will provide power to the load and/or battery as needed (shown in Figure 52) and in detailed in Appendix D.

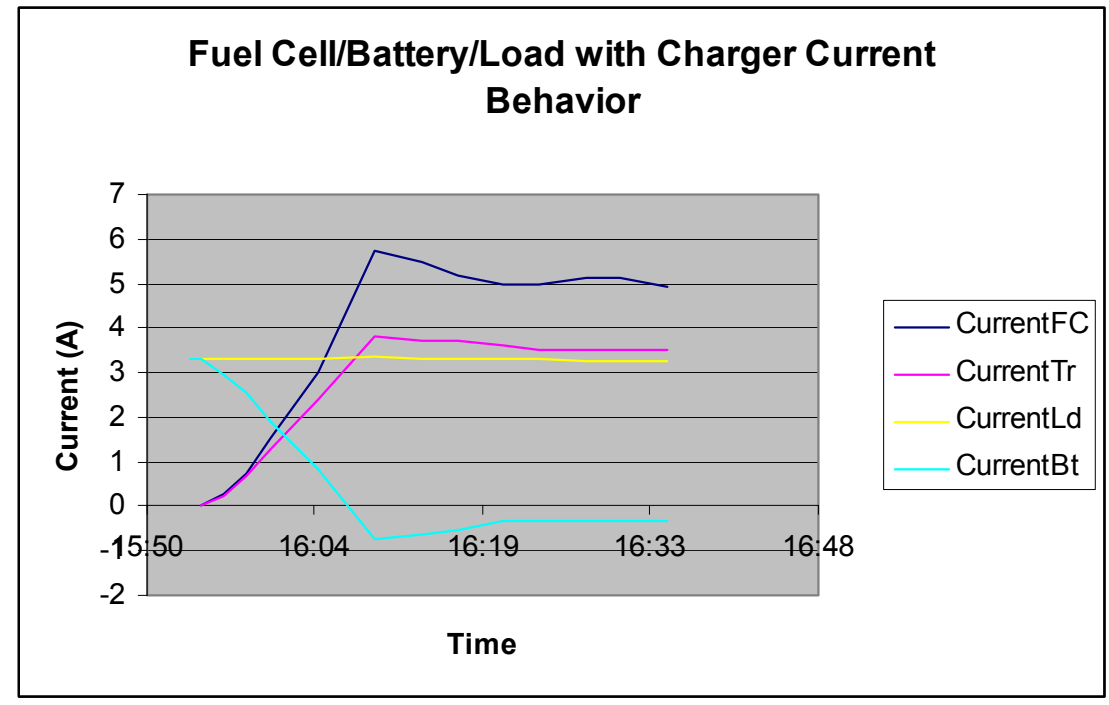

Figure 52: Fuel Cell/Battery/Load current behavior with charger

While the charger is steadily increasing the current it is provided to the system, the battery will provide the needed current to the load. As before, the charger will provide the needed current to raise the battery voltage to 14.3 , or max out at $5 \mathrm{~A}$, and will maintain that maximum voltage until the battery is charged to the point where that current can be decreased. The fuel cell will provide as much power as needed by the load as it can before trying to charge the battery as well. If the power is increased to above what the fuel cell and charger can provide alone, the battery will add what power the load requires.

\subsection{Discussion}

According to the test results, the Jadoo purging system seems to have a large affect on controlling the stability of the power output by clearing out the contaminants or excess water and by maintaining the pressure in the stack. The fan is required to introduce air into the system and cool down the stack, and with all loads above approximately $30 \mathrm{~W}$ when the temperature is typically above $115^{\circ} \mathrm{F}$, the fan appears to run continuously at max speed. The fuel cell appears to work most efficiently at loads 
between 30-60W, which appears to be the time when the fan is used to introduce the most sufficient amount of air into the stack and the purging is only used every 20 minutes. From running the Horizon fuel cell stack, it was determined that, running the fuel cell without the fan will cause a minor drop in performance even at the lowest loads. The average energy per gram of hydrogen in this range was $18.8 \mathrm{Wh} / \mathrm{g}$, which was almost $60 \%$ of the maximum value of the theoretical electrical energy generated in the fuel cell, which is $32.7 \mathrm{Wh} / \mathrm{g}$ [1].

The Horizon fuel cell was the more challenging to control as it also offered more aspects of the fuel cell system for the user to manually control. It was determined that, while still requiring purging more often than the Jadoo, it does not in fact require it every 10 seconds. Thus, the controller of the Horizon fuel cell was redesigned to allow the user to control the purging. Threshold purging appeared to offer the most stability while preventing the voltage from continuously falling. Even as the Horizon did not quite perform as well as the Jadoo as it achieved at best $18.6 \mathrm{Wh} / \mathrm{g}$ at its lowest power output, it did allow for increased understanding of how the convection PEM fuel cell systems operate, which will help in developing improved control methods. A fuel cell model was developed based on the experimental data to simulate the effects of the dead-end anode on the output stack's voltage.

The Triton Battery Charger was determined capable of control the output of the fuel cell when charging of a battery from a fuel cell and power a variable load. A charger and battery setup would prevent the fuel cell from experiencing the large variable shifts that could cause damage to cell's components. This charger was limited by its low current range (5A max) and in the future more advanced versions of the charger that allow for higher currents and faster startups should be examined. 


\section{Chapter 5: Dead-Ended Anode PEM Model}

\subsection{Introduction}

The current method to determining the optimal purge frequency of the dead-end anode is to monitor the water production of the fuel cell by means of measure certain process parameters while the fuel cell is allowed to run during dead-end mode, and purging after reaching a determined threshold value [35]. While run in dead-end mode, the voltage will drop over time at a rate proportional to the current output. At relatively low current, the voltage will barely change at all, while at higher currents it is more pronounced, necessitating a higher purge frequency needed to purge the anode side and restore the balance in the fuel cell [36]. Because of the cost of experimentation with purging on an actual fuel cell that may cause a water imbalance and damage the delicate polymer membrane, a model was developed based on empirical equations and experimental data of the fuel cells' flow rate, temperature, voltage and current obtained in the previous section.

\subsection{Model Subsystems}

A model in the MATLAB/SIMULINK environment was developed based on the experimental results of the Jadoo fuel cell. Figure 53, pictured below, shows the interactions of the fuel cell model's subsystem.

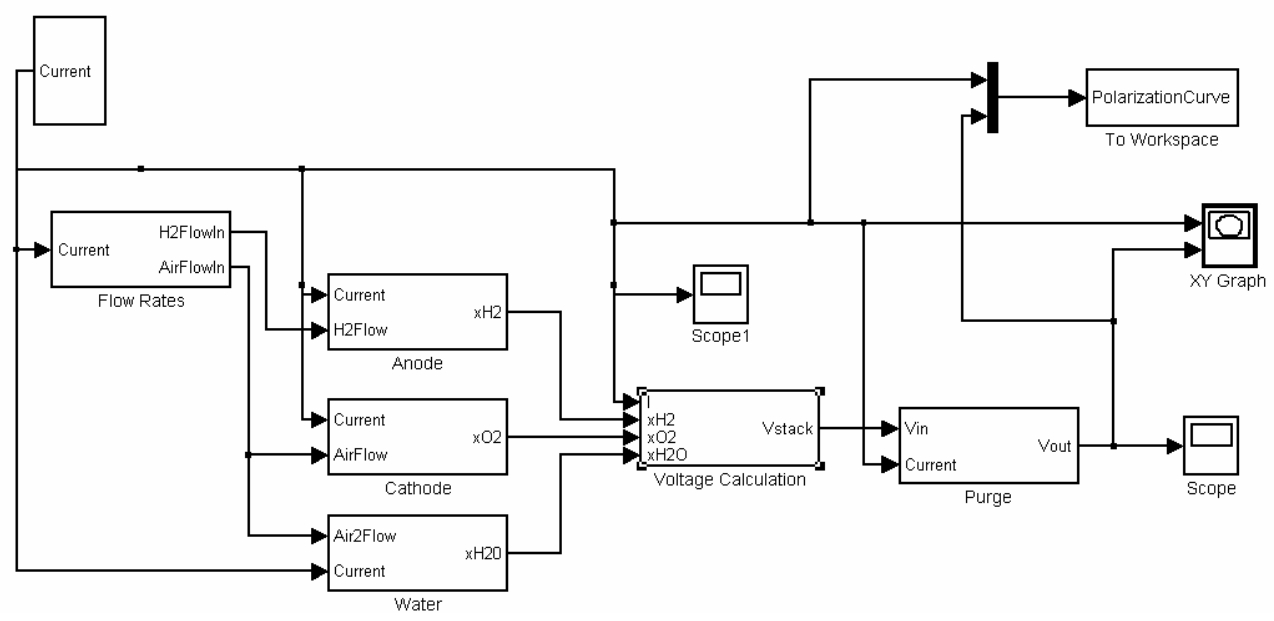

Figure 53: Subsystem Model Block Diagram 
The assumptions of the model include:

- Ideal gas properties and mixtures,

- Uniform gas and temperature distribution,

- Temperature and nitrogen effects are negligible, and

- Voltage drop due to dead end mode is due to a change in the hydrogen flow through the channels [36].

The current required of the fuel cell stack was used to determine the flow rates of the air and hydrogen inputs as presented in Section 4.3. In the Anode, Cathode, and Water subsystems [37], the mole fraction of the species was calculated and used as inputs into calculating the Nernst voltage and voltage losses.

\subsubsection{Gas Flow}

\section{Variables:}

I : Stack current (A)

$\mathrm{M}_{\mathrm{i}}^{\mathrm{in}} \quad$ : Input molar flow rates $(\mathrm{mol} / \mathrm{s})$ of species $\mathrm{i}$

$\mathrm{M}_{\mathrm{i}}^{\mathrm{r}} \quad$ : Molar reaction rates $(\mathrm{mol} / \mathrm{s})$ of species $\mathrm{i}$

$\mathrm{M}_{\mathrm{t}} \quad$ : Total molar flow rate $(\mathrm{mol} / \mathrm{s})$ of the stack

$\mathrm{u}_{\mathrm{i}} \quad$ : Molar fraction species $\mathrm{i}$

$\mathrm{T} \quad$ : Temperature of the stack $(\mathrm{K})$

$\mathrm{P} \quad$ : Pressure of the stack (atm)

F : Faraday's Constant $(\mathrm{C} / \mathrm{mol})$

R : Gas Constant $(\mathrm{J} / \mathrm{molK})$

\section{Equations:}

Determining the molar fractions of the reactant gases that travel through the anode and cathode layers are determined using the ideal gas law. The equations [37] representing the species balance equation in terms of the input flow rates is as follows:

$$
(P V) /(R T)^{*} \dot{u}_{\mathrm{i}}^{\mathrm{o}}=\mathrm{M}_{\mathrm{t}}^{\text {in }}{ }^{*} \mathrm{x}_{\mathrm{i}}^{\text {in }}-\left(\mathrm{M}_{\mathrm{t}}^{\mathrm{in}}-\mathrm{M}_{\mathrm{t}}^{\mathrm{r}}\right) * \mathrm{u}_{\mathrm{i}}^{\mathrm{o}}+\mathrm{M}_{\mathrm{i}}^{\mathrm{r}}
$$

The rate the species react are given with the following [37]: 


$$
\begin{gathered}
M_{H 2}{ }^{r}=M_{t}^{r}=-I /(2 F) \\
M_{O 2}{ }^{r}=-M_{H 2 O}{ }^{r}=2 M_{t}^{r}
\end{gathered}
$$

The simulink model of the anode subsystem with the input hydrogen molar flow is shown in Figure 54. The models for the subsystems for the cathode and water production [37] are similar.

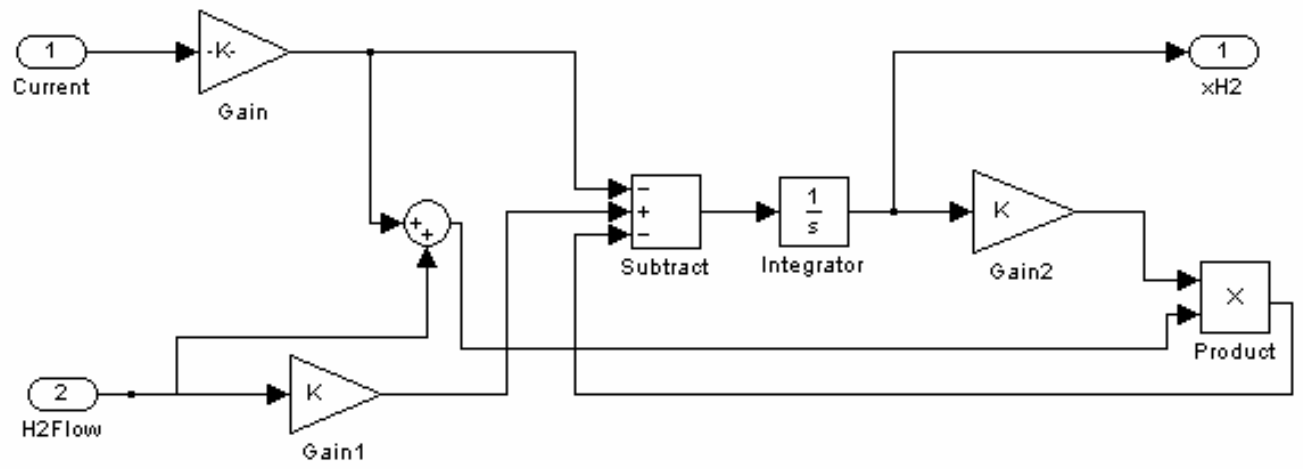

Figure 54: Anode Hydrogen Flow

\subsubsection{Voltage Calculation}

\section{Variables:}

I $\quad$ : Stack current (A)

$\mathrm{I}_{\mathrm{o}} \quad$ : Reference exchange current (A)

$\mathrm{I}_{\mathrm{L}} \quad$ : Limiting current $(\mathrm{A})$

$\mathrm{u}_{\mathrm{i}} \quad$ : Molar fraction species i $(\mathrm{V})$

$\mathrm{V}_{\text {stack }} \quad$ : Stack voltage $(\mathrm{V})$

$\mathrm{V}_{\mathrm{o}} \quad$ : Output Nernst voltage (V)

$\mathrm{V}_{\mathrm{r}} \quad$ : Ohmic voltage loss (V)

$\mathrm{V}_{\text {act }} \quad$ : Activation voltage loss $(\mathrm{V})$

$\mathrm{V}_{\text {conc }} \quad$ : Concentration voltage loss $(\mathrm{V})$

$\mathrm{E}_{\mathrm{r}} \quad$ : Reversible cell potential (V)

$\mathrm{n}$ : Number of electrons in the reaction 
$\mathrm{R}_{\mathrm{i}} \quad$ : Internal Ohmic resistance (Ohms)

$\alpha \quad$ : Transfer coefficient

$\mathrm{N}_{\text {cell }} \quad$ Number of cells in the stack

\section{Equations:}

The overall voltage of the stack is simulated in Figure 55 with the following equation:

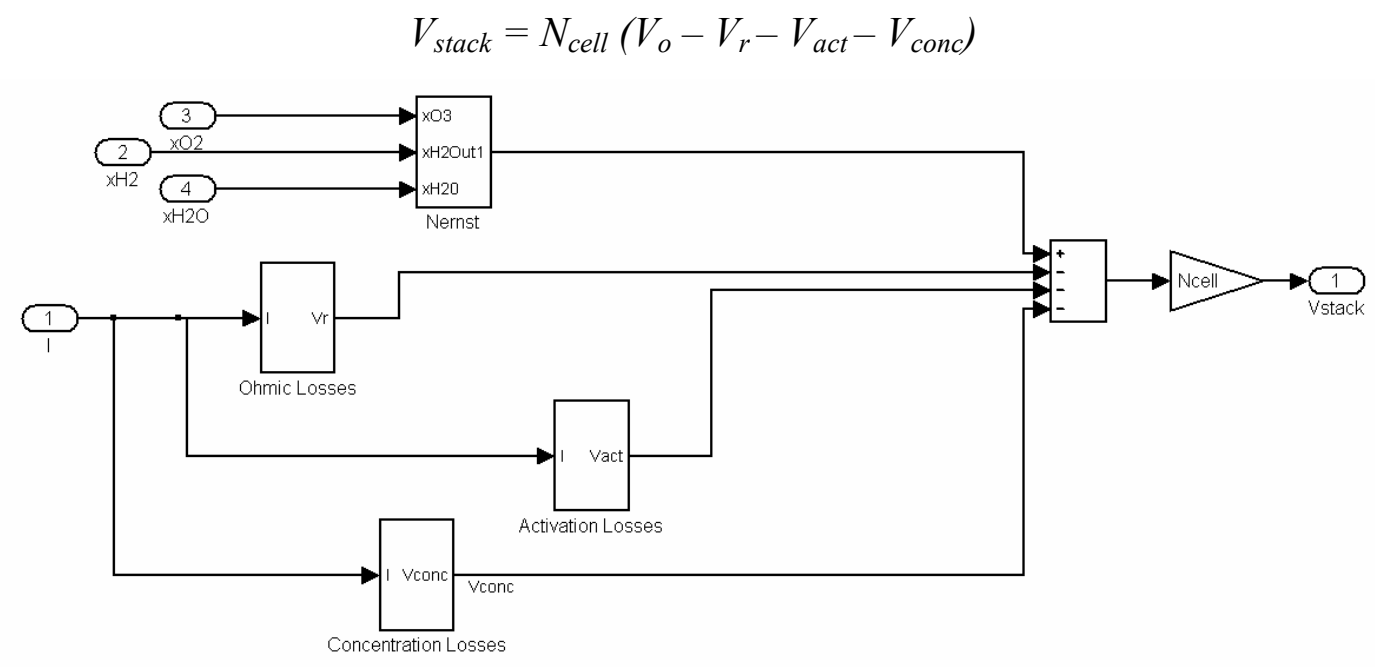

Figure 55: Voltage Calculation

The Nernst voltage is given with the following equation:

$$
V_{o}=E_{r}+(R T) /(n F) * \ln \left\{\left(x_{O 2} *_{H_{2}}\right) / x_{H 2 O}\right\}
$$

The Ohmic voltage loss is given with the following equation:

$$
V_{r}=I * R_{i}
$$

The activation voltage loss can be calculated with the Tafel equation and is simulated in Figure 56:

$$
\begin{gathered}
V_{a c t}=a+b \log (I) \\
a=-2.3 *(R T) /(\alpha F) \log (\operatorname{Io}) \text { and } b=2.3 *(R T) /(\alpha F) .
\end{gathered}
$$




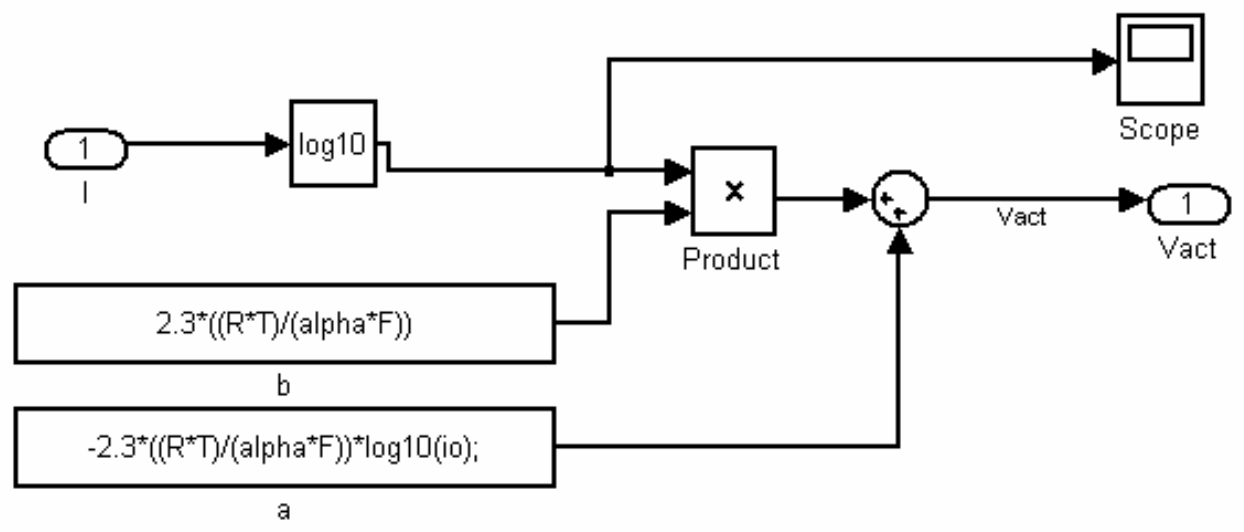

Figure 56: Activation Voltage Loss Model

The concentration voltage loss is given with the following equation and is simulated in Figure 57:

$$
V_{\text {conc }}=E_{r}+(R T) /(n F) * \ln \left\{\left(x_{O 2} * x_{H 2}\right) / x_{H 2 O}\right\}
$$

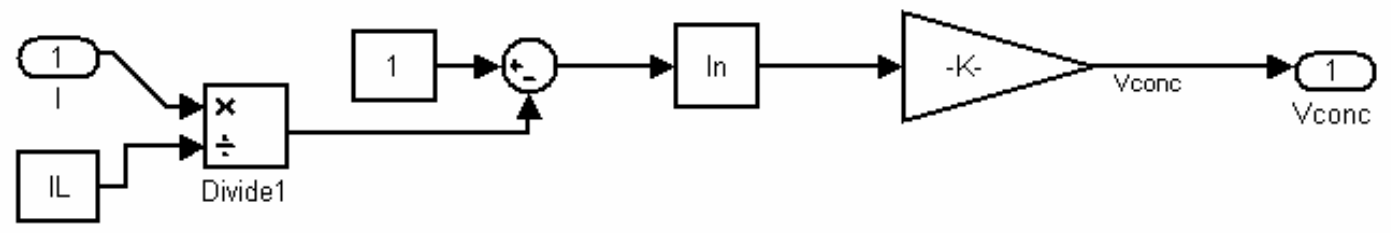

Figure 57: Concentration Voltage Loss Model

\subsubsection{Dead-End Anode Subsystem}

To simulate the voltage decreasing over time due to the dead-end anode, the rate the voltage fell over time per was determined for each current of the fuel cells based on the experimental data. This gave the following voltage drop rate per current equation pictured in Figure 58 and simulated in Figure 59. 


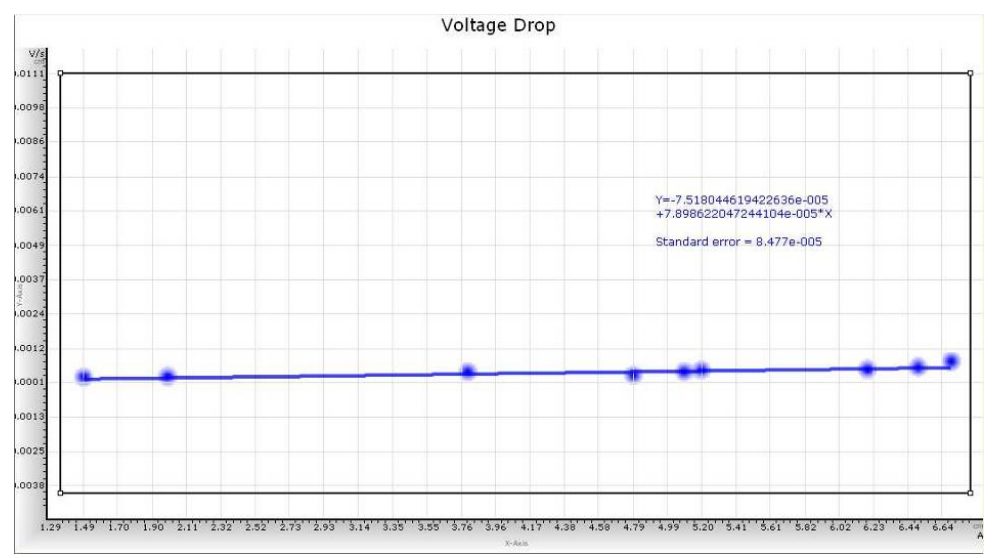

Figure 58: Voltage Drop over Time per Ampere

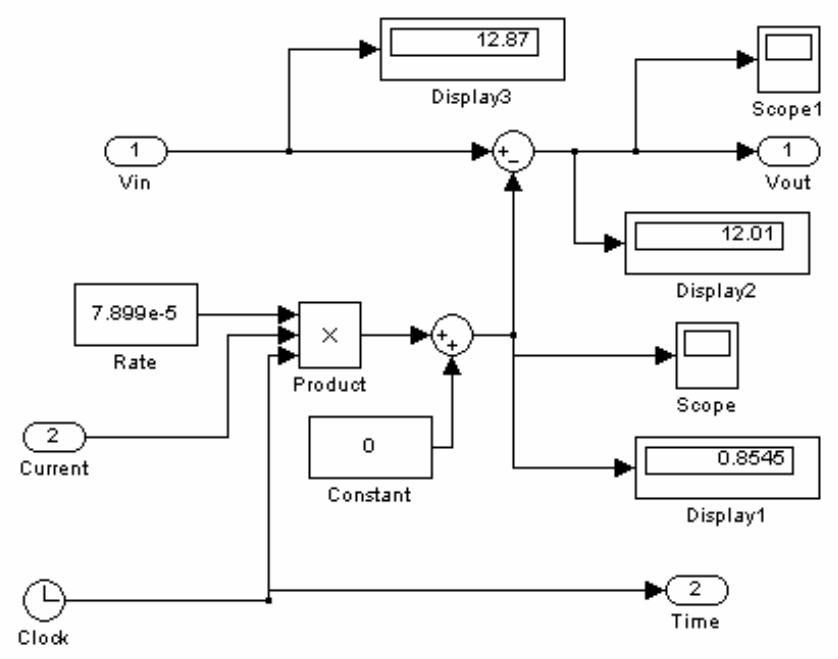

Figure 59: Dead-End Anode Simulation

\subsection{Results}

Figure 60 presents the model's IV-Curve as compared to the Jadoo experimental results.

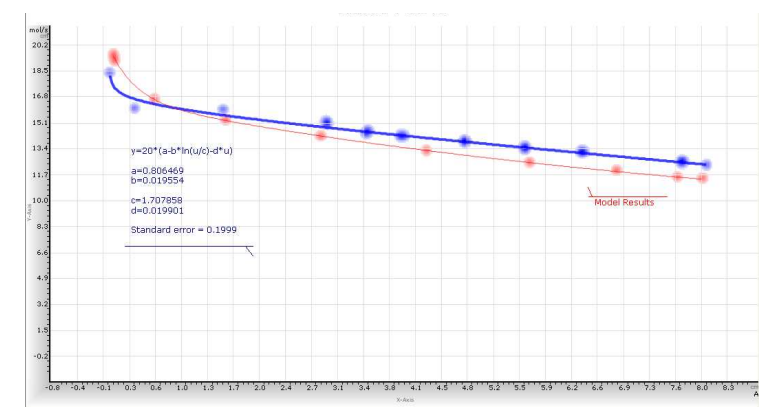

Figure 60: Model and Jadoo IV Curves 
The voltage affected by changes in the current and over time is shown in Figure 61, while the difference between the model as run with and without the dead-ended anode voltage drop with a constant load is shown in Figure 62. While the voltage is higher than the experimental values because the model did not account for changes in temperature or internal pressures, the aim of simulating the voltage drop over time was comparable with the expected results.

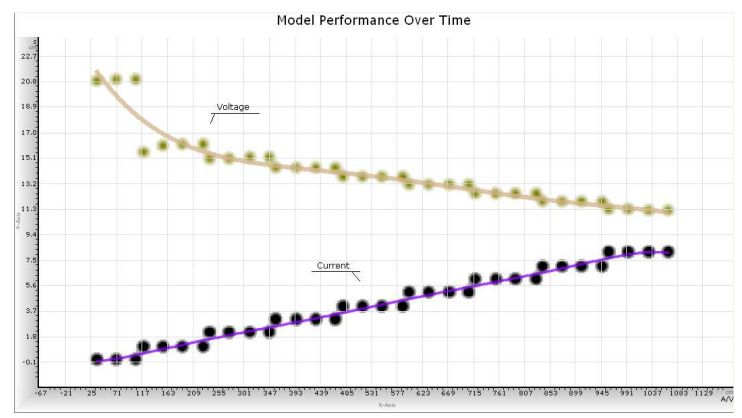

Figure 61: Model Performance Over Time With Increasing Current

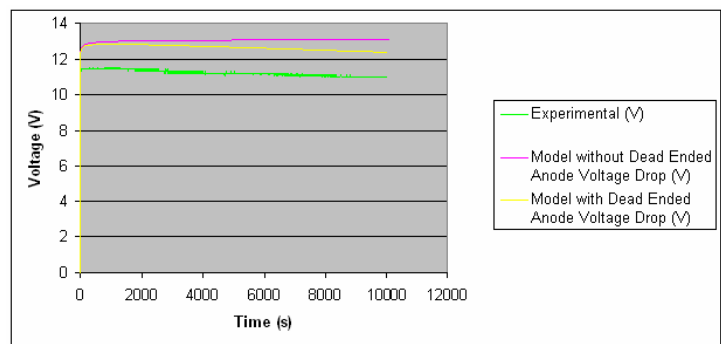

Figure 62: Model Output With and Without the Dead-Ended Anode Voltage Drop

While the voltage is higher than the experimental values because the model did not account for changes in temperature or internal pressures, the aim of simulating the voltage drop over time was comparable with the expected results. 


\section{Chapter 6: Conclusions and Future Work}

\subsection{Conclusions}

By observing the performance of two similar PEM fuel cells, the efficiency of their control systems could be compared and evaluated. The purging system was determined to have a large part in maintaining the performance of the fuel cell over time, with the fuel cell's output consistently deteriorating over time if kept dead-ended. Purging too often also had the effects of wasting hydrogen and unbalancing the internal pressures of the fuel cell. It was determined that the period between purges was most effective when dependent on the power drawn from the fuel cell and the rate of the fuel cell's voltage drop.

The Jadoo purging system appears to work most efficiently at loads between 40$70 \mathrm{~W}$, which appears to be the time when the fan was used to introduce the most sufficient amount of air into the stack and the purging period was 20 minutes. The average practical efficiency of the $100 \mathrm{~W}$-rated fuel cell was $42 \%$, while the peak practical efficiency $48 \%$ at $62 \mathrm{~W}$. When run at higher power outputs that required more frequent purging, there was a small decline in the efficiency; and the fuel cell's lowest efficiency occurred when run at the low power outputs of $20 \mathrm{~W}$ or less when most of the power from the fuel cell was diverted to the control unit. The average energy per gram of hydrogen in this range was $18.8 \mathrm{Wh} / \mathrm{g}$, which was almost $60 \%$ of the maximum value of the theoretical electrical energy generated in the fuel cell, which is $32.7 \mathrm{Wh} / \mathrm{g}$ [1]. The fan is required to introduce air into the system and cool down the stack, and with all loads above approximately $30 \mathrm{~W}$ when the temperature is typically above $115^{\circ} \mathrm{F}$, the fan appears to run continuously at max speed. The Jadoo fuel cell was also used to demonstrate the performance of the fuel cell in a hybrid system with a battery in reaching loads twice that of the capabilities of the fuel cell alone, demonstrating how the fuel cell's controller operated with a supplemental system.

The Horizon fuel cell was the more challenging to control as it also offered more aspects of the fuel cell system for the user to manually control. It was determined that, while still requiring purging more often than the Jadoo, it does not in fact require it every 
10 seconds. Thus, the controller of the Horizon fuel cell was redesigned to allow the user to control the purging. Threshold purging appeared to offer the most stability while preventing the voltage from continuously falling. The Horizon had an overall average efficiency at $34 \%$, and a higher efficiency when run at lower power outputs. Its highest measured efficiency peaked at $48 \%$ at $11 \mathrm{~W}$, which was when the fuel cell required the lowest purging frequency. Higher power outputs that required more frequent purging steadily declined in efficiency. Even as the Horizon did not quite perform as well as the Jadoo, achieving at best $18.6 \mathrm{Wh} / \mathrm{g}$ at its lowest power output, it did allow for increased understanding of how the convection PEM fuel cell systems operate, which will help in developing improved control methods.

A model was developed in the MATLAB/SIMULINK environment using the basic empirical equations and the experimental to demonstrate the voltage drop over time due to the dead-ended anode. The model could be used to simulate the Jadoo fuel cell and determine how often the fuel cell would need to be purged.

\subsection{Future Work}

Continued efforts will be directed toward exploring the effects of maintaining the anode in the dead-ended mode for durations of time on the fuel cell stack's pressure and flow rate throughout specific areas of the stack and attributing such effects to the voltage and current performance. Thus it should enable a model to be developed that could be configurable to the active area of the fuel cell. Also in the future, a different DC-DC converter needs to be determined that would better adjust the output power of the fuel cell for the hybridized systems. 


\section{Bibliography}

[1] Barbir, Frano. PEM Fuel Cells: Theory and Practice. Elsevier Academic Press. 2005. pp8, 33-69, 132-142

[2] O'Hayre, Ryan, Suk-Won Cha, Whitney Colella, and Fritz B. Prinz. Fuel Cell Fundamentals. John Wiley \& Sons, Inc. 2006.

[3] Dhar, Hari P. "Medium-Term Stability Testing of Proton Exchange Membrane Fuel Cell Stacks as Independent Power Units.” BCS Fuel Cells.

[4] Leboe, David. "Method and system for controlling the operation of a hydrogen generator and a fuel cell." Cellex Power Product, Inc. 2005.

[5] Giustiniani, A. et al. "PEM Fuel Cells Control by means of the Perturb and Observe Technique.” IEEE. 2006.

[6] Vega-Leal, Alfredo P. et al. "Design of Control Systems for Portable PEM Fuel Cells.” Journal of Power Sources vol 169. pp 194-197. 2007.

[7] "Fuel Cell Control with Fuzzy System." Institute for Innovative Informatics Applications. 2007.

[8] Liu, Guidong et al. "Power Management for Alleviation of the Impact on PEM Fuel Cell due to Load Fluctuation." Proceedings of the Sixth International Conference on Intelligent Systems Design and Applications. 2006.

[9] Yi, Jung S. "Water Management along the Flow Channels of PEM Fuel Cells." AIChE Journal vol 50. pp 2594-2603. 2004. 
[10] Buie, Cullen R. "Water management in proton exchange membrane fuel cells using integrated electroosmotic pumping." Journal of Power Sources vol 161. pp 191-202. 2006.

[11] Knobbe, M.W. et al. "Active gas management for PEM fuel cell stacks." Journal of Power Sources vol 138. pp 94-100. 2004.

[12] Vipperman, Jeffery S. et al. Research in Flow Control in Fuel Cells at the University of Pittsburgh. 2004.

[13] Hahn, Robert. "Thermal Management of Portable Micro Fuel Cell Stacks." 19th IEEE SEMI-THERM Symposium. 2003.

[14] Kim, Min-Joong and Huei Peng. "Power management and design optimization of fuel cell/battery hybrid vehicles." Journal of Power Sources vol 165. pp 819832. 2007.

[15] El-Shatcr, Thanaa Fawzy. "Power Management of PV/Fuel Cell System." 3rd World Conference on Photovoltaic Energy Conversion. 2003.

[16] Eichenberg, Dennis J. "Hybrid Power Management Program Developed a FuelCell-Powered Utility Vehicle." 2006.

[17] "NREL: Hydrogen and Fuel Cells Research." $<$ http://www.nrel.gov/hydrogen/proj_production_delivery.html>. 2006.

[18] "Innovagen Fuel Processor Product Sheet." $<$ http://www.tekkie.com/innovagen.htm>. 2007.

[19] Castaldi, Marco et al. "Performance of Microlith Based Catalytic Reactors for an Isooctane Reforming System.” 2003. 
[20] "Compact Microlith Logistics Fuel Processors for Fuel Cell Power Systems." Precision Combustion, Inc. 2007.

[21] "HY9-Products-Reformers." <http://hy9.com/reformers.html>. 2007.

[22] "ECOtotality." <http://www.ecotality.com/>. 2007.

[23] Bauer, Dana. "Hydrogen: What Form Fits?" $<$ http://www.rps.psu.edu/hydrogen/form.html>. 2005.

[24] Dumé, Belle. "New Look for Hydrogen Storage.” PhysicsWorld. 2005.

[25] 'N-Gen Users' Guide.” Jadoo. 2006.

[26] "H-100 PEM Fuel Cell System." < http://www.horizonfuelcell.com/file/HSeries.pdf>. 2007.

[27] “N-Stor Users' guide.” Jadoo. 2006.

[28] “225 Liter Solid State Hydrogen Canister.” < http://www.fuelcellstore.com/cgibin/tornado/view $=I$ tem $/$ cat=5/product=1183> 2007.

[29] "Neodym Technologies - Hydroknowz Hydrogen Gas Monitors." $<$ http://www.neodymsystems.com/n_hydroknowz.shtml $>$. 2007.

[30] “NI USB-6009.” > http://sine.ni.com/nips/cds/view/p/lang/en/nid/14605>. 2007.

[31] "Fluke LH410 LEM AC/DC Clamp-on Ammeter." $<$ http://www.tequipment.net/FlukeLH410FE.html>. 2007.

[32] "Sartorius GP5202 Precision Balance." Precision Weighing Balances. $<$ http://sartorius.balances.com/sartorius/gp5202.html>. 2007. 
[33] "Eagle Picher CF-12V7.2 Sealed Lead Acid Battery." $<$ http://www.batteryuniverse.com/>. 2007.

[34] “Great Planes ElectriFly Triton DC Comp Peak Charger." HalfEight. $<$ http://shop.tinyrc.com/product.php?productid=16344>. 2007.

[35] Herron, Thomas G. "System and Method for Optimizing Fuel Cell Purge Cycles." Patent No. 6,887,605 B2. 2005.

[36] Dumercy, L. et al. "PEFC Stack Operating in Anodic Dead-End Mode." Fuel Cells 2004, 4, No. 4.

[37] Sedghisigarchi, Kourosh. "Solid Oxid Fuel Cell as a Distributed Generator: Dynamic Modeling, Stability Analysis and Control.” WVU. Morgantown, WV. 2004. 


\section{Appendices}

Appendix A: Horizon Low and High Power Output Tests in Detail

\begin{tabular}{|r|r|r|r|r|r|r|r|r|}
\hline $\begin{array}{c}\text { Time } \\
\text { (h:m) }\end{array}$ & $\begin{array}{c}\text { Current } \\
\text { (A) }\end{array}$ & $\begin{array}{r}\text { Voltage } \\
\text { (V) }\end{array}$ & $\begin{array}{c}\text { Temp } \\
\text { (F) }\end{array}$ & $\begin{array}{c}\text { Tank } \\
\text { Pressure } \\
\text { (psi) }\end{array}$ & $\begin{array}{c}\text { Input } \\
\text { Valve } \\
\text { Pressure } \\
\text { (psi) }\end{array}$ & $\begin{array}{c}\text { Power } \\
\text { (W) }\end{array}$ & $\begin{array}{c}\text { Fan } \\
\text { Speed } \\
\text { (\%) }\end{array}$ & $\begin{array}{c}\text { Tank } \\
\text { Weight } \\
\text { (g) }\end{array}$ \\
\hline 0.00 & 0.00 & 0.00 & 72.6 & 0 & 0 & 0.00 & 0 & 2180.83 \\
\hline 0.00 & 0.00 & 24.98 & 74.4 & 120 & 7.2 & 0.00 & 50 & \\
\hline 0.00 & 0.00 & 21.10 & 75.2 & 120 & 6.2 & 0.00 & 50 & \\
\hline 0.01 & 0.83 & 21.51 & 78.9 & 118 & 6 & 17.85 & 50 & \\
\hline 0.01 & 0.83 & 21.47 & 79.9 & 117 & 5.8 & 17.82 & 50 & \\
\hline 0.01 & 0.83 & 21.30 & 80.4 & 116 & 5.8 & 17.68 & 50 & \\
\hline 0.01 & 0.81 & 21.22 & 80.7 & 115 & 5.6 & 17.19 & 50 & \\
\hline 0.01 & 0.82 & 21.19 & 80.8 & 114 & 5.6 & 17.38 & 50 & \\
\hline 0.01 & 0.84 & 21.16 & 80.9 & 112 & 5.6 & 17.77 & 50 & \\
\hline 0.01 & 0.85 & 21.22 & 81.0 & 110 & 6.6 & 18.04 & 50 & \\
\hline 0.02 & 0.82 & 21.19 & 81.0 & 110 & 6.5 & 17.38 & 50 & \\
\hline 0.02 & 0.81 & 21.19 & 81.2 & 108 & 6.4 & 17.16 & 50 & \\
\hline 0.02 & 0.82 & 21.16 & 81.2 & 107 & 6.2 & 17.35 & 50 & \\
\hline 0.02 & 0.82 & 21.16 & 81.2 & 106 & 6.2 & 17.35 & 50 & \\
\hline 0.02 & 0.00 & 21.10 & 81.4 & 105 & 6 & 0.00 & 50 & \\
\hline 0.03 & 0.00 & 0.00 & 77.3 & 0 & 0 & 0.00 & 0 & 2180.46 \\
\hline 0.03 & 0.00 & 24.56 & 76.3 & 110 & 6 & 0.00 & 20 & \\
\hline 0.03 & 0.00 & 13.82 & 91.4 & 110 & 6.4 & 0.00 & 20 & \\
\hline 0.03 & 5.55 & 11.60 & 111.8 & 105 & 6 & 64.38 & 20 & \\
\hline 0.03 & 5.85 & 12.75 & 119.0 & 100 & 5.8 & 74.59 & 20 & \\
\hline 0.03 & 6.45 & 14.75 & 129.0 & 90 & 5.2 & 95.14 & 50 & \\
\hline 0.04 & 6.89 & 16.69 & 138.0 & 80 & 6.8 & 114.99 & 50 & \\
\hline 0.04 & 6.86 & 16.41 & 141.0 & 77 & 6.4 & 112.57 & 50 & \\
\hline 0.04 & 6.84 & 16.20 & 144.0 & 70 & 7.2 & 110.81 & 50 & \\
\hline 0.04 & 6.77 & 16.12 & 136.4 & 68 & 7.2 & 109.13 & 50 & 2178.85 \\
\hline
\end{tabular}


Appendix B: Jadoo hydrogen flow test in detail

\begin{tabular}{|c|c|c|c|c|c|c|c|c|}
\hline & Power & Voltage & Current & $\%$ & LPM & PPM & $\mathrm{L}$ & Time \\
\hline $13: 56$ & 0 & 16.8 & 0.02 & 97 & 0.06 & 0 & 0.099 & $1: 30: 00$ \\
\hline $13: 58$ & 0 & 16.6 & 0.03 & 97 & 0.06 & 2400 & 0.199 & 3:00:00 \\
\hline $14: 00$ & 7 & 15.6 & 0.54 & 97 & 0.13 & 2400 & 0.411 & 5:30:00 \\
\hline 14:01 & 6 & 15.7 & 0.55 & 97 & 0.13 & 2400 & 0.547 & $6: 30: 00$ \\
\hline 14:02 & 15 & 15.2 & 1.04 & 97 & 0.21 & 2800 & 0.737 & 7:30:00 \\
\hline 14:03 & 15 & 15.3 & 1.04 & 97 & 0.21 & 2000 & 0.954 & $8: 30: 00$ \\
\hline $14: 04$ & 23 & 14.9 & 1.55 & 97 & 0.28 & 800 & 1.222 & 9:30:00 \\
\hline $14: 05$ & 23 & 15 & 1.55 & 97 & 0.29 & 400 & 1.563 & $10: 40: 00$ \\
\hline 14:06 & 31 & 15 & 2.02 & 97 & 0.37 & 0 & 1.914 & $11: 40: 00$ \\
\hline 14:07 & 30 & 14.9 & 2.02 & 97 & 0.37 & 0 & 2.222 & $12: 30: 00$ \\
\hline 14:08 & 38 & 14.4 & 2.5 & 97 & 0.45 & 0 & 2.663 & $13: 30: 00$ \\
\hline 14:09 & 37 & 14.3 & 2.5 & 96 & 0.45 & 0 & 3.119 & $14: 30: 00$ \\
\hline $14: 10$ & 43 & 14 & 2.88 & 96 & 0.52 & 0 & 3.619 & $15: 30: 00$ \\
\hline $14: 11$ & 43 & 14 & 2.89 & 96 & 0.52 & 0 & 4.233 & $16: 40: 00$ \\
\hline $14: 12$ & 48 & 13.8 & 3.29 & 96 & 0.59 & 0 & 4.805 & $17: 40: 00$ \\
\hline $14: 13$ & 48 & 13.9 & 3.29 & 96 & 0.59 & 0 & 5.299 & $18: 30: 00$ \\
\hline $14: 14$ & 53 & 13.7 & 3.73 & 96 & 0.65 & 0 & 6.042 & $19: 40: 00$ \\
\hline $14: 15$ & 55 & 13.9 & 3.79 & 95 & 0.66 & 0 & 6.594 & $20: 30: 00$ \\
\hline $14: 16$ & 60 & 13.7 & 4.16 & 95 & 0.72 & 0 & 7.301 & $21: 30: 00$ \\
\hline $14: 17$ & 61 & 13.8 & 4.16 & 95 & 0.73 & 0 & 8.029 & 22:30:00 \\
\hline $14: 18$ & 65 & 13.6 & 4.55 & 95 & 0.78 & 0 & 8.795 & $23: 30: 00$ \\
\hline $14: 19$ & 65 & 13.6 & 4.55 & 94 & 0.78 & 0 & 9.585 & $24: 30: 00$ \\
\hline $14: 20$ & 70 & 13.4 & 4.92 & 94 & 0.84 & 0 & 10.411 & $25: 30: 00$ \\
\hline $14: 21$ & 70 & 13.4 & 4.93 & 94 & 0.84 & 0 & 11.73542 & $26: 40: 00$ \\
\hline $14: 22$ & 74 & 13.3 & 5.27 & 93 & 0.9 & 0 & 12.135 & $27: 30: 00$ \\
\hline $14: 23$ & 75 & 13.3 & 5.29 & 93 & 0.9 & 0 & 13.168 & $28: 40: 00$ \\
\hline $14: 24$ & 78 & 13.1 & 5.64 & 93 & 0.96 & 0 & 14.282 & $29: 50: 00$ \\
\hline $14: 25$ & 78 & 13.1 & 5.62 & 92 & 0.95 & 0 & 15.225 & $30: 50: 00$ \\
\hline $14: 26$ & 81 & 12.9 & 5.94 & 92 & 1 & 0 & 16.208 & $31: 05: 00$ \\
\hline $14: 27$ & 82 & 12.9 & 5.95 & 92 & 1 & 0 & 17.233 & $32: 50: 00$ \\
\hline $14: 28$ & 85 & 12.7 & 6.26 & 91 & 1.05 & 0 & 18.787 & $34: 20: 00$ \\
\hline $14: 29$ & 85 & 12.7 & 6.25 & 91 & 1.05 & 0 & 19.844 & $35: 20: 00$ \\
\hline $14: 30$ & 87 & 12.6 & 6.52 & 90 & 1.1 & 0 & 20.932 & $36: 20: 00$ \\
\hline 14:31 & 88 & 12.6 & 6.54 & 90 & 1.1 & 0 & 21.852 & $37: 10: 00$ \\
\hline 14:32 & 90 & 12.4 & 6.8 & 90 & 1.14 & 0 & 23.173 & $38: 20: 00$ \\
\hline $14: 33$ & 90 & 12.4 & 6.77 & 89 & 1.14 & 0 & 23.937 & 39:00:00 \\
\hline 14:34 & 100 & 12.8 & 7.35 & 89 & 1.24 & 0 & 25.14 & 40:00:00 \\
\hline $14: 35$ & 101 & 12.9 & 7.37 & 88 & 1.24 & 0 & 26.595 & $41: 10: 00$ \\
\hline
\end{tabular}




\section{Appendix C: Jadoo Fuel Cell/Battery with Charger testing without load results}

\begin{tabular}{|r|r|r|r|r|r|r|r|r|r|r|}
\cline { 2 - 2 } & \multicolumn{3}{|c|}{ Fuel Cell } & \multicolumn{3}{|c|}{ Triton } & \multicolumn{3}{c|}{ Load } & Battery \\
\hline Time & P_FC & V_FC & C_FC & V_Tr & C_Tr & P_Tr & V_Ld & C_Ld & P_Ld & C_Bt \\
\hline $12: 08$ & 0 & 0 & 0 & 0 & 0 & 0 & 11.84 & 0 & 0 & 0 \\
\hline $12: 12$ & 0 & 16.2 & 0 & 0 & 0 & 0 & 11.84 & 0 & 0 & 0 \\
\hline $12: 13$ & 1 & 15.8 & 0.06 & 12.79 & 0.1 & 1.28 & 11.93 & 0 & 0 & -0.15 \\
\hline $12: 15$ & 9 & 14.8 & 0.61 & 13.3 & 0.6 & 7.98 & 12.15 & 0 & 0 & -0.66 \\
\hline $12: 16$ & 15 & 14.2 & 1.06 & 13.58 & 0.9 & 12.22 & 12.38 & 0 & 0 & -0.99 \\
\hline $12: 17$ & 20 & 15.4 & 1.30 & 13.82 & 1.1 & 15.20 & 12.5 & 0 & 0 & -1.27 \\
\hline $12: 18$ & 25 & 15.1 & 1.66 & 14 & 1.4 & 19.6 & 12.59 & 0 & 0 & -1.59 \\
\hline $12: 19$ & 31 & 14.9 & 2.08 & 14.1 & 1.7 & 23.97 & 12.67 & 0 & 0 & -1.81 \\
\hline $12: 21$ & 44 & 14.3 & 3.08 & 14.35 & 2.3 & 33.01 & 12.82 & 0 & 0 & -2.38 \\
\hline $12: 23$ & 43 & 14.1 & 3.05 & 14.32 & 2.3 & 32.94 & 12.83 & 0 & 0 & -2.39 \\
\hline $12: 25$ & 44 & 14 & 3.14 & 14.3 & 2.3 & 32.89 & 12.83 & 0 & 0 & -2.38 \\
\hline
\end{tabular}




\section{Appendix D: Jadoo Fuel Cell/Battery with Charger testing with load results}

\begin{tabular}{|r|r|r|r|r|r|r|r|r|r|r|}
\hline \multicolumn{4}{|c|}{} & \multicolumn{3}{|c|}{ Fuel Cell } & \multicolumn{3}{c|}{ Triton } & \multicolumn{3}{|c|}{ Load } & Battery \\
\hline Time & P_FC & V_FC & C_FC & V_Tr & C_Tr & P_Tr & V_Ld & C_Ld & P_Ld & C_Bt \\
\hline $15: 54$ & 0 & 0.00 & 0.00 & 0.00 & 0.00 & 0.00 & 11.97 & 3.32 & 39.7404 & 3.32 \\
\hline $15: 55$ & 0 & 16.3 & 0.00 & 0.00 & 0.00 & 0.00 & 11.96 & 3.31 & 39.5876 & 3.31 \\
\hline $15: 57$ & 4 & 15.3 & 0.26 & 12.99 & 0.2 & 2.60 & 11.95 & 3.29 & 39.3155 & 2.98 \\
\hline $15: 59$ & 11 & 14.8 & 0.74 & 13.23 & 0.7 & 9.26 & 11.99 & 3.3 & 39.567 & 2.53 \\
\hline $16: 01$ & 24 & 15.4 & 1.56 & 13.47 & 1.3 & 17.51 & 12.01 & 3.31 & 39.7531 & 1.88 \\
\hline $16: 05$ & 43 & 14.4 & 2.99 & 13.77 & 2.4 & 33.05 & 12.13 & 3.3 & 40.029 & 0.82 \\
\hline $16: 10$ & 75 & 13.1 & 5.73 & 14.4 & 3.8 & 54.72 & 12.46 & 3.35 & 41.741 & -0.76 \\
\hline $16: 14$ & 72 & 13.1 & 5.50 & 14.35 & 3.7 & 53.10 & 12.52 & 3.33 & 41.6916 & -0.65 \\
\hline $16: 17$ & 70 & 13.5 & 5.19 & 14.35 & 3.7 & 53.10 & 12.54 & 3.33 & 41.7582 & -0.51 \\
\hline $16: 21$ & 67 & 13.4 & 5.00 & 14.26 & 3.6 & 51.34 & 12.46 & 3.3 & 41.118 & -0.33 \\
\hline $16: 24$ & 67 & 13.4 & 5.00 & 14.26 & 3.5 & 49.91 & 12.47 & 3.3 & 41.151 & -0.32 \\
\hline $16: 28$ & 68 & 13.3 & 5.11 & 14.31 & 3.5 & 50.09 & 12.42 & 3.27 & 40.6134 & -0.31 \\
\hline $16: 31$ & 68 & 13.2 & 5.15 & 14.3 & 3.5 & 50.05 & 12.5 & 3.24 & 40.5 & -0.34 \\
\hline $16: 35$ & 67 & 13.6 & 4.93 & 14.31 & 3.5 & 50.09 & 12.45 & 3.26 & 40.587 & -0.33 \\
\hline
\end{tabular}

